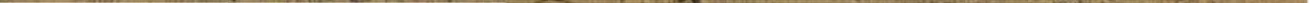


 \\ 31295013473151}

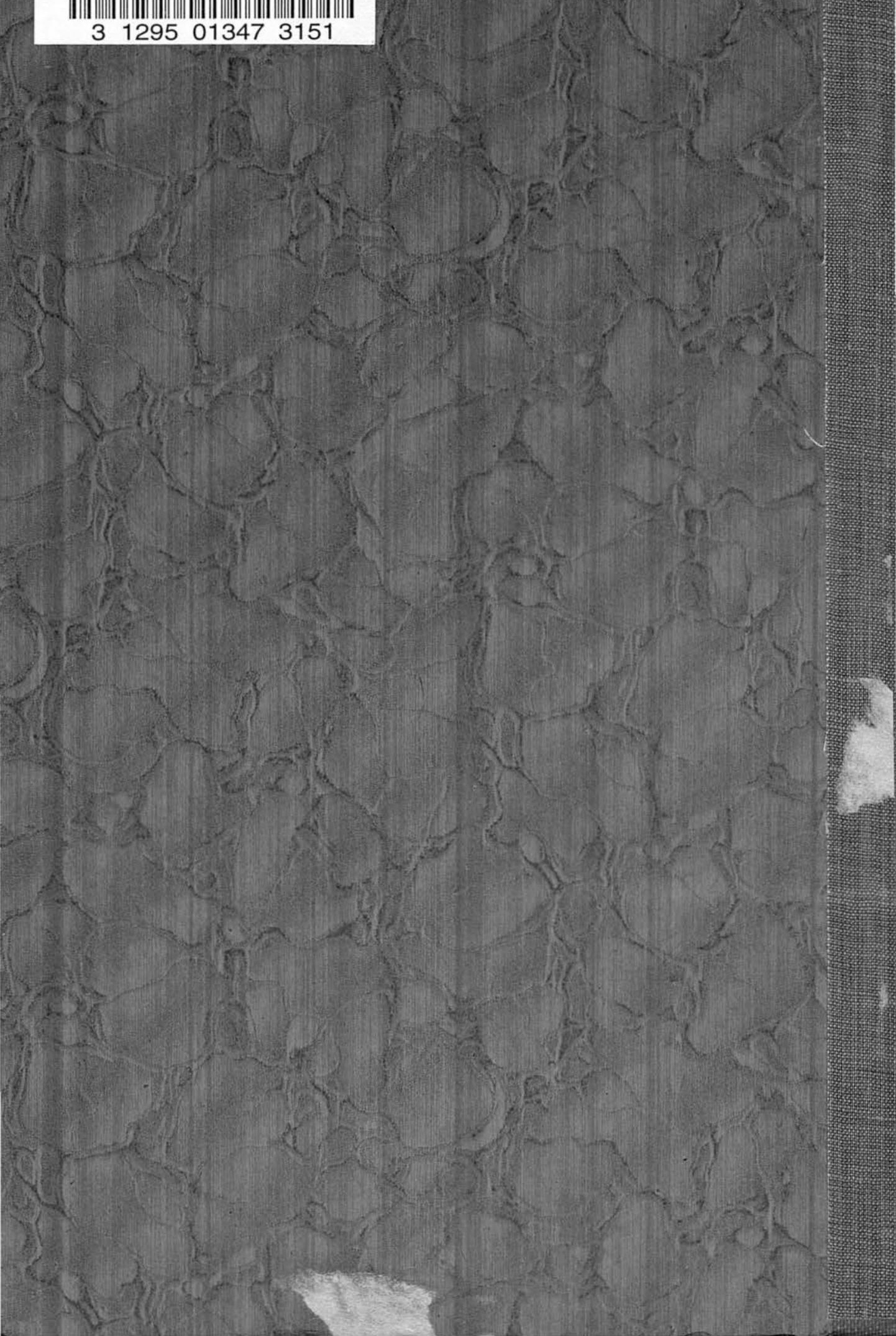


DEPARTMENT OF THE INTERIOR

UNITED STATES GEOLOGICAL SURVEY

GEORGE OTIS SMITH, DIRECTOR

Bulletin 548

\title{
ELECTRIC ACTIVITY IN ORE DEPOSITS
}

\author{
BY \\ ROGER C. ẈELLS
}

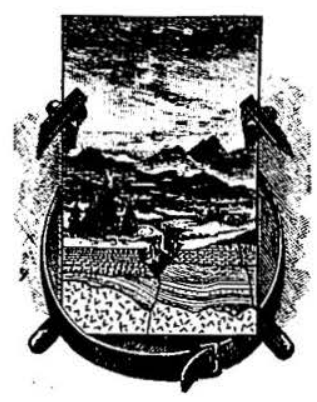

WASHINGTON

GOVERNMENT PRINTING OFFICE

1914 



\section{CONTENTS.}

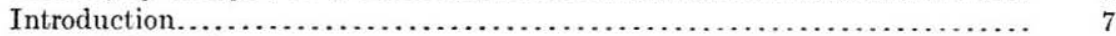

General discussion of the phenomena............................. 9

Effect of various solutions on the potentials shown by minerals........ 9

Availability of the combinations to furnish current................. 12

Electric currents in the earth.................................. 19

Effect of a current from solution to mineral..................... 21

Method of experiment.................................... 21

Effects at the cathode with moderate currents................... 21

Effects at the cathode with feeble currents.................... 22

Effect of a current from mineral to solution........................ 23

Electric conductivity of minerals........................... 24

Detailed study of various potentials.................................. 26

General results of the measurements........................... 26

Measurements of potential assumed by certain minerals.............. 30

Pyrolusite............................................ 30

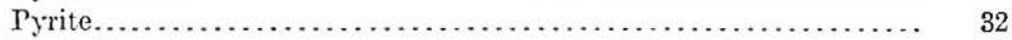

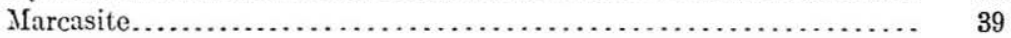

Pyrrhotite............................................ 41

Magnetite............................................ 41

Galena.......................................... 42

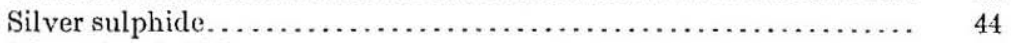

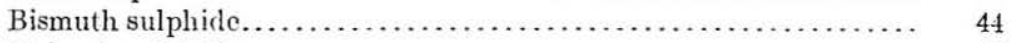

Mercuric sulphirle.................................... 45

Nickel and other sulphides............................ 45

Electromotive behavior of soluble sulphides.................... 45

Reducing power of soluble sulphides...................... 45

Relation between potential and concentration................ 47

Preparation of sodium hydrosulphide..................... 48

Chemistry of the sulphide electrode....................... 49

Behavior of polysulphides............................... 51

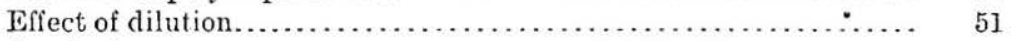

Conclusions ........................................ 54

Correlation of the measurements of potential.................... 54

Application to ore deposition.................................... 62

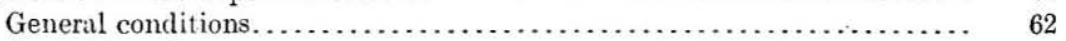

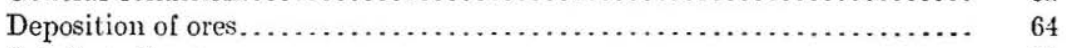

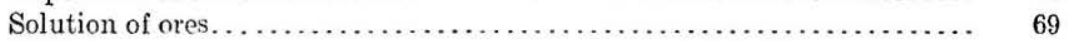

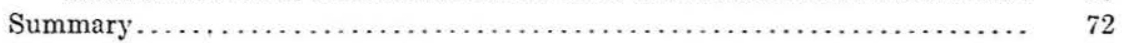

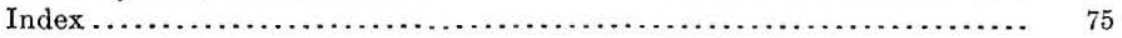




\section{ILLUSTRATIONS.}

Figure 1. Apparatus for studying currents produced by combinations of solutions and minerals................................... 13

2. Method of supplying fresh solution to mineral electrodes without affording access of air..................................

3. Half cell of mineral suspended in a solution for observation over a long period............................................

4. Apparatus for boiling out air under reduced pressure before meas-

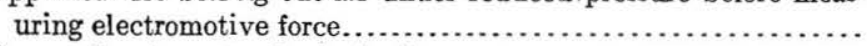

5. Curves showing rate of polarization..........................

6. Mounting of pyrite to obtain a saturated solution over a long period without access of air................................. 38

7. Single potentials of oxygen and hydrogen electrodes in water..... 58 4 


\section{PREFACE.}

\section{By George Otis Smith.}

Until the last few years the contributions to the study of ore deposits by members of the United States Geological Survey have been primarily geologic. Close observation of the facts of geologic occurrence and mineral association has been the rule, less attention having been given to the chemical and physical questions involved in problems of ore deposition. Notable exceptions have been studies by G. F. Becker and Carl Barus ${ }^{1}$ of electric activity in the Comstock lode and the lodes of Eureka, Nev., the chemical investigation by Becker and Melville of solution and precipitation of metallic sulphides, ${ }^{2}$ studies by C. R. Van Hise and C. K. Leith ${ }^{3}$ of the chemistry of ironore deposition, and the work of Waldemar Lindgren ${ }^{4}$ on the relations between ore deposition and physical conditions. Recently, however, unusual interest has been awakened in the geochemical and geophysical phases of the problem. This interest has manifested itself in such work as that of Victor Lehner, ${ }^{5}$ of the University of Wisconsin, and A. D. Brokaw, ${ }^{6}$ of the University of Chicago, on the solution and deposition of gold, and in studies begun by L. C. Graton, of Harvard University, and his associates, of the enrichment of copper ores.

Among the contributions already made by the United States Geological Survey are the published results of studies by W. H. Emmons ${ }^{7}$ of the general subject of enrichment, and of investigations now being carried on by E. S. Bastin ${ }^{8}$ and Chase Palmer of the enrichment of silver ores as exemplified in our western mining camps. The work reported in the present paper on electric activity in ore deposits elaborates and extends the work of Gottschalk and Buehler. ${ }^{9}$.

\footnotetext{
1 Geology of the Comstock lode and the Washoe district: U. S. Geol. Survey Mon. 3, pp. 309-367, 1882.

2 Geology of the quicksilver deposits of the Pacific slope: U. S. Geol. Survey Mon. 13, chap. 15, 1888.

8 Summarized in U. S. Geol. Survey Mon. 52, pp. 518-545, 1911.

4 Ore deposition and deep mining: Econ. Geology, vol. 1, pp. 34-46, 1905; The relation of ore deposition to physical conditions: Idem, vol. 2, pp. 105-127, 1907.

6 The transportation and deposition of gold in nature: Econ. Geology, vol. 7, pp. 744-750, 1912.

B The secondary precipitation of gold in ore bodies: Jour. Geology, vol. 21, pp. 251-267, 1913.

7 The enrichment of sulphide ores: U.S. Geol. Survey Bull. 529, 1913.

8 Metasomatism in downward sulphide enrichment: Econ. Geology, vol. 8, pp. 51-63, 1913; Metallic minerals as precipitants of silver and gold: Idem, pp. 140-170, 1913.

- Econ. Geology, vol. 5, pp. 28-35, 1910; vol. 7, pp. 15-34, 1912.
} 
It is interesting to note that this bulletin by $\mathrm{Mr}$. Wells relates to a subject mentioned by Becker ${ }^{1}$ in his first administrative report to Director King as deserving study, a suggestion that was followed by the investigation by Barus. The electromotive forces detected in the present detailed quantitative laboratory studies of the activity of various metalliferous minerals in various solutions show few intensities as great as one volt, though some of them are many times greater than the largest electromotive forces actually found in ore deposits by the earlier observers. Moreover, the effects of difference in solutions are found to be greater than those due to mineralogic differences.

It should be emphasized that the results thus far obtained afford no adequate basis for any method of electric prospecting nor any promise of the development of such a method by connecting the presence of ore deposits with readily or definitely measurable electric activity. Nevertheless, the data here presented are believed to possess value in the broader investigation of ores, for even feeble currents might exert a directional influence on ore deposition, and chemical conditions, even at a distance, might be a factor in determining mineral association.

1 U. S. Geol. Survey First Ann. Rept., p. 46, 1880. 


\title{
ELECTRIC ACTIVITY IN ORE DEPOSITS.
}

\author{
By Roger C. Wells.
}

\section{INTRODUCTION.}

As long ago as $1830 \mathrm{R}$. W. Fox called attention to electric activity in ore deposits. ${ }^{1}$ Such currents as he was able to detect seemed to have no relation to the points of the compass, but appeared to be due to connections existing between different bodies of ore, or between different parts of the same body. In one mine the ore appeared to be increasingly negative with depth, a fact which he suggested might be dependent on temperature. His original paper contained a table showing the order of the electric conductivity of about twenty minerals and mineral combinations. In a later paper ${ }^{2}$ he took pains to show that certain ores may act like metals in galvanic combinations, and his principal conclusions are summed up in the statement that the electric phenomena in veins "bear a striking resemblance to galvanic combinations." From 1830 to 1844 discussion of these points was carried on by Henwood ${ }^{3}$ and Fox ${ }^{4}$ in England and by Von Strombeck ${ }^{5}$ and Reich ${ }^{6}$ in Germany without important advances.

The subject was considered from a somewhat different point of view in 1870 by W. Skey. ${ }^{7}$. Whereas the preceding investigators had sought for currents over large areas, Skey confined his observations to laboratory experiments on single minerals. He enlarged the known list of conducting minerals and determined the direction of

\footnotetext{
1 Fox, R. W., On the electromagnetic properties of metalliferous veins in the mines of Cornwall: Philos. Trans., 1830, pt. 2, p. 399.

2 Fox, R. W., Note on the electric relations of certain metals and metalliferous minerals: Philos. Trans., 1835 , pt. 1 , p. 39.

3 Henwood, W.J., Sur les courants électriques ol)servés dans les filons de Cornouailles: Annales des mines, 3d ser., vol. 11, p. 585, 1837 .

4 Fox, R. W., Account of some experiments on the electricity of the Huel Jewel mine: British Assoc. Adv. Sci. Rept., vol. 3, p. 572, 1834; Report on some experiments on the electricity of metallic veins, etc.: Idem, vol. 6, p. 133, 1837; Some experiments on subterranean electricity, made at Pennance mine, near Falmouth: Philos. Mag., 3d ser., vol. 23, pp. 457, 491, 1843.

o Strombeck, A. von, Ueler die von Herrn Fox angestellten Untersuchungen in Bezug auf die elektromagnetischen Aeusserungen der Metallgänge: Karsten's Archiv, vol. 6, p. 431, 1833.

6 Reich, F., Notiz über elektrische Ströme auf Erzgängen: Poggendorff's Annalen, vol. 4S, p. 287, 1839; Versuche über die Aufsuchung von Erzen mittelst des Schweiger'schen Afultiplicators: Berg- und hüttenmänn'sche Zeitung, vol 3, pp. 342, 386, 1844.

$\tau$ Skey, W., On the electromotive power of metallic sulphides: New Zealand Inst. Trans. and Proc., vol. 3, pp. 232-236. 1871.
} 
the current when conducting minerals in contact with solutions are connected by a wire. Besides pointing out anew that conducting minerals are capable of forming the electrodes of galvanic batteries he called attention to the accelerating or retarding action of one mineral on another in chemical changes-action due to electric activity.

In 1880, at the instance of G. F. Becker, Carl Barus ${ }^{1}$ investigated the electric activity of the Comstock lode and of the ore deposits at Eureka, Nev. Although he followed the experimental methods of Fox, Barus appears to have purposely avoided contact with metalliferous minerals. He concluded, from the measurements made at the Comstock lode " that the electromotive forces due purely to chemical difference and polarization of the terminals are of the same order as the data expressing the electric activity of the lode." At Eureka the potentials of 21 points were measured against a single point of reference with terminals particularly designed to make a good contact with the solutions in the rocks. The maximum potential above the point of reference was 0.018 volt and the maximum below 0.093 volt. In the words of Barus:3 "On reviewing the results described it is strikingly evident that the electromotive forces met with are invariably small, very frequently, indeed, quite at the limit of the accurately measurable." Electric prospecting, therefore, appeared to Barus impracticable, but he adds: ${ }^{4}$

It will be desirable to carry out Fox's original idea, namely, of investigating the electrical properties of ores and minerals of the heavy metals ****. The knowledge we possess of the conductivity and the position of ores in the electrical scale is largely the result of experiments made a long time ago. Recent observers have made but few quantitative additions, and even these-probably from improperly chosen methods-are frequently discordant.

In 1891 Braun $^{5}$ clearly proved that certain phenomena attending the formation of sulphides and the deposition of copper in capillary spaces, previously noted by A. C. Becquerel, are of an electrochemical nature, as Becquerel had in fact suggested. ${ }^{\beta}$ These phenomena are partly dependent, according to Ostwald, ${ }^{7}$ on the semipermeability of precipitated membranes. It is not possible in this paper, however, to discuss the complications that would be introduced into the question by so extending it as to consider capillary spaces and semipermeable membranes.

\footnotetext{
1 Becker, G. F., Geology of the Comstock lode and the Washoe district: U. S. Geol. Survey Mon. 3, pp. 309-367 (chap. 10, On the electrical activity of ore bodies, by Carl Barus), 1882.

2 Idem, p. 322.

${ }^{3}$ Idem, p. 365.

I Idem, p. 366.

5 Braun, F., Electrocapillare Reactionen: Annalen der Physik und Chemie, vol. 44, p. 507, 1891.

6 Becquerel, A. C., Sur des nouveaux effets chimiques produits dans les actions capillaires: Compt. rend., vol. 64 , pp. 919-924, 1867; vol. 65 , pp. 51-60, 720-729, 1867; vol. 66, pp. 77-81, 245-247, 766-924, 1066-1072, 1868; particularly vol. 65 , p. $51,1868$.

7 Ostwald, W., Elektrische Eigenschaften halbdurchlässiger Scheidewände: Zeitschr.physikal. Chemle, vol. 6 , p. 75,1890 .
} 
Experiments along the line indicated by Barus were made in 1897 by Bernfeld, ${ }^{1}$ who studied the electric behavior of galena particularly, and more recently by Gottschalk and Buehler, who had previously shown that the oxidation and solution of certain natural sulphides are accelerated under certain conditions by the presence of pyrite or marcasite. ${ }^{2}$ In explanation of this action E. T. Allen ${ }^{3}$ and $I^{4}$ separately ventured to express the opinion that it might be due to the production of sulphuric ácid by the pyrite and marcasite. Soon afterward, in another paper, Gottschalk and Buehler pointed out once more that there may be electric action between different sulphides in contact; further, that marcasite and pyrite, which are electrically positive to stibnite and sphalerite when in moist contact with them, are in fact themselves somewhat protected from oxidation by the complementary action of the more oxidizable sulphides. They accordingly ascribed the chemical effects observed by them partly to electric action, and presented a list of conducting minerals and a table giving the electromotive forces shown by several minerals with respect to copper, water serving as electrolyte.

This explanation of the alteration of ores by electrolysis is similar to the electrolytic theory of the corrosion of iron and steel and of the zinc of zinc plate. In view of the importance of the subject it has seemed desirable to extend the data, not only to correlate field results with laboratory experiments, but also to elucidate the effect of various solutions on the potentials and to harmonize the whole subject with modern theories, such as those of electricity and solution. The data presented in this bulletin greatly enlarge the scope of possible investigation. It is well realized that more detailed experimental work is both desirable and necessary, but it has seemed best to set forth at this time what has already been done.

\section{GENERAI DISCUSSION OF THE PHENOMENA.}

\section{EFFECT OF VARIOUS SOLUTIONS ON THE POTENTIALS SHOWN BY MINERALS.}

The potentials of different minerals as presented by Gottschalk and Buehler were determined by using water as the electrolyte and metallic copper as the second electrode. ${ }^{5}$ Their opinion was that the electrolytic action of the sulphides "would be analogous in every respect to the action of metals." But although it is well known that the potential shown by a metal as electrode depends on the concentration of the metallic ion in the solution in contact with it, Gottschalk and Buehler presented no data on the effect of variation in the solution.

2 Bernfeld, I., Studien über Schwefelmetallelektroden: Zeitschr. physikal. Chemie, rol. 25, p. 46, 1898

2 Buehler, H. A., and Gottschalk, V. H., Oxidation of sulphides: Econ. Geology, vol. 5, p. 28, 1910.

3 Econ. Geology, vol. 5, p. 387, 1910.

- Idem, p. 480.

¿ Gottschalk, V. H., and Buehler, H. A., Econ. Geology, vol. 7, p. 31, 1912. 
This was therefore the first subject to be investigated. A few measurements soon showed that not only do different minerals employed as electrodes exhibit different potentials in a given solution but also that the potentials shown by most minerals, certainly the initial values, depend to a marked degree on the nature of the solutions in contact with the minerals. The variation shown by a mineral in passing from an acid to an alkaline solution is in fact generally greater than the differences shown by diverse minerals in the same solution. The potentials also depend on the oxidizing or reducing nature of the solutions. In general, acid and oxidizing solutions give the highest potentials, alkaline and reducing solutions the lowest.

A most significant fact for the elucidation of these phenomena is that any unattackable electrode, such as a piece of smooth platinum, shows somewhat similar behavior in the various solutions. The table below gives a few single potential measurements which illustrate this point. The solutions were approximately normal and the sign is that assumed by the electrode with reference to the normal calomel electrode as +0.560 volt, the measurements being made soon after the specimens were placed in the solutions. Of course neither equilibrium nor constancy was wholly obtained under these circumstances in the time allowed.

Effect of various solutions on the potential, in volts.

\begin{tabular}{|c|c|c|c|c|c|}
\hline & Pyrite. & Galena. & Magnetite. & Pyrrhotite. & Platinum. \\
\hline 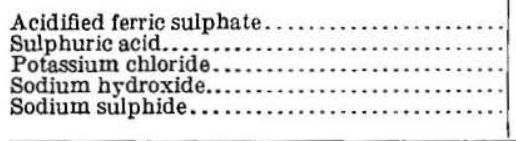 & $\begin{array}{l}+1.10 \\
+.86 \\
+.72 \\
+.38 \\
+.17\end{array}$ & $\begin{array}{r}+0.80 \\
a+.49 \\
+.49 \\
a+.16 \\
-.22\end{array}$ & $\begin{array}{l}+0.91 \\
+.88 \\
+.68 \\
+.53 \\
-.14\end{array}$ & $\begin{array}{r}+0.97 \\
+.89 \\
+.56 \\
a+.13 \\
a-.14\end{array}$ & $\begin{array}{l}+1.11 \\
+.97 \\
+.76 \\
+.38 \\
+.26\end{array}$ \\
\hline
\end{tabular}

a Mineral appreciably attacked, yielding an indefinite value.

On considering these results a number of important questions at once arise. Is it possible to frame a consistent explanation of all the values? How constant and reproducible are they? Which of them, if any, are capable of furnishing noteworthy currents for electrolytic action? Is such action possible in ore deposits? If so, what are the effects of electrolytic action on various minerals? I shall attempt to give answers to these questions by discussing known facts as well as by presenting new experimental evidence on the subject.

It may be said at once that most of these potentials are reproducible to tenths of a volt and some to hundredths. Our knowledge of the behavior of various electrodes would lead us to expect, however, that the products formed by solution of the minerals would have an effect on the potentials. To yield significant potentials the solutions 
should contain definite concentrations of the possible reacting substances, but as the concentrations could not be regulated by the method of experimentation used above the values are simply illustrative and have no exact quantitative significance.

The measurements are suggestive, however, because they represent temporary stages in slow chemical adjustments. Some of these adjustments occur very slowly, so slowly that fairly constant potentials are soon obtained; others occur more rapidly and the reaction products cause a changing potential. Measurements of electromotive force may be used to indicate the direction and intensity of a given chemical action and generally furnish such indications with as great accuracy as chemical experimentation. Moreover, such measurements may be made quickly.

The potentials shown by the minerals and the platinum as indicated in the preceding table evidently have something in common and are affected in a similar way by the nature of the solutions. The variations shown seem to be characteristic of the potentials ordinarily termed "oxidation and reduction" potentials. When the electrode appears positive the usual assumption is that positive electricity has passed from some ion in the solution to the conductor (platinum ordinarily), or, what amounts to the same thing, that negative electricity has passed from the electrode to the solution. The ferric ions present in a ferric salt solution, for example, are capable of acting as oxidizers - that is, of parting with a portion of their electrification and thereby becoming converted into ferrous ions. The electric potential measures the tendency of this chemical process to occur. Evidently this general effect is shown even with the mineral electrodes in the above measurements, but with the minerals there is the added possibility that their constituents may ionize and carry electric charges with them into the solution as they dissolve. Considering the similar effects shown by the minerals and by platinum, however, it must be said that the potentials indicate in a general way the order of the oxidizing power of the solutions.

For further measurements of such potentials one may refer to the experiments made by Bancroft on a large number of oxidizing and reducing solutions. ${ }^{1}$ In $1898 \mathrm{R}$. Peters showed that the value of the ferric-ferrous potential is dependent on the concentrations of both ferric and ferrous salt, and succeeding investigators have found that such potentials are much more definite when the salts of both valencies are present in about equal amounts. The present custom is to take as the normal oxidation and reduction potential the value shown when the two ions concerned, if these can be determined, are present

1 Buncroft, W. D., Ueber Oxydationsketten: Zeitschr. physikal. Chemie, vol. 10, p. 387, 1892. 
in equal concentration. The single ferric-ferrous potential, for example, can be represented by the following equation: ${ }^{1}$

$$
\mathrm{E}=1.016+0.059 \log \frac{\left[\mathrm{Fe}^{+++}\right]}{\left[\mathrm{Fe}^{++}\right]}
$$

in which $\mathrm{E}$ is the potential in volts and the bracketed symbols stand for concentrations of the respective ions. It can be seen that at equal concentrations of ferric and ferrous ions the second term vanishes. The value 1.016, then, represents the single potential of the ferric-ferrous electrode provided the normal calomel electrode has a potential of 0.560 volt. The electromotive behavior of substances possessing several stages of oxidation has been very fully studied and discussed by $R$. Luther. ${ }^{2}$

There can be no question, then, that the potentials shown by unattackable electrodes are related to the oxidizing or reducing. nature of the solutions in contact with them, and further, that a number of the common metalliferous minerals exhibit initial potential values which may obviously be referred to the same cause.

These facts may possibly help us to explain in part the electromotive forces noted in the earth by Fox. The solutions in the upper levels of ore deposits are likely to be oxidizing and acid, but with increase in depth they become more reducing and less acid. For these reasons isolated portions of ore in the upper levels may possess a higher electric potential than portions in the lower levels, and such detectable electric currents as might be caused by this difference would be more likely to take a vertical than a horizontal direction. Of course variations in the nature of the solutions might also give rise to differences in potential in horizontal directions. However, the presence of dissimilar solutions in contact with ores suggests a very probable cause of differences of potential in the earth.

\section{AVAILABILITY OF THE COMBINATIONS TO FURNISH CURRENT.}

It appeared to be a matter of practical importance to determine whether the above potentials could yield currents available for producing appreciable chemical action or whether such electrodes are very easily polarizable. This question was accordingly put to an experimental test.

There seems to be no question about the competency of an oxidizing solution like acidified ferric sulphate to furnish a noteworthy current when a platinum electrode is employed as a cathode and conjoined with any unpolarizable anode. In order to compare this action with that occurring when electrodes of pyrite are involved

${ }^{1}$ See Noyes, A. A., and Brann, B. F., The equilibrium of the reaction between metallic silver und ferric nitrate: Am. Chem. Soc. Jour., vol. 34, p. 1025, 1912.

${ }^{2}$ Luther, R., Zeitschr. physikal. Chemie, vol. 34, p. 487, 1900; vol. 36, p. 385, 1901. 
the following experiments were performed: In one beaker was placed an acidified solution of ferric sulphate, in another beaker a solution of sodium sulphide (see fig. 1), both solutions being approximately normal. The platinum electrodes measured 2 by 2 centimeters. The beakers were connected by a wick saturated with normal sodium sulphate. (See fig. 1.) The potential of this combination on open circuit, calculated by the data in the table on page 10 , is 0.93 volt. The external circuit was completed by a voltmeter and sufficient additional resistance was introduced to bring the total resistance of the circuit, including the resistance of the liquid (all resistances being actually determined), up to $3,000 \mathrm{ohms}$, which is comparable to the resistance of some geologic strata. On closing the circuit the electromotive forces and currents tabulated below were noted, the electromotive

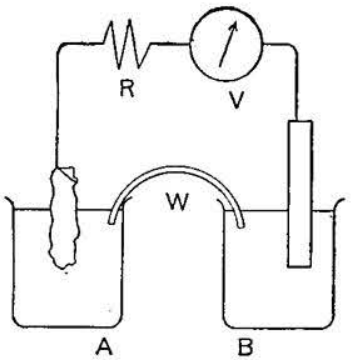

FIGURE 1.-Apparatus for study. ing currents produced by combinations of solutions and minerals. A, B, beakers containing solutions; $\mathrm{R}$, resistance; $\mathrm{V}$, voltmeter; W, wick or tube. force stated being equivalent to the fall in potential over the whole circuit.

Oxidation and reduction current with platinum electrodes.

\begin{tabular}{|c|c|c|}
\hline Time. & $\begin{array}{l}\text { Effective } \\
\text { electromo- } \\
\text { tive force. }\end{array}$ & Current. \\
\hline $\begin{array}{l}0.1 \text { minute....... } \\
1 \text { minute.......... } \\
5 \text { minutes....... } \\
10 \text { minutes...... } \\
16 \text { hours.......... }\end{array}$ & $\begin{array}{r}\text { Ioll. } \\
0.96 \\
.94 \\
.94 \\
.88 \\
.76\end{array}$ & $\begin{array}{r}\text { Milli- } \\
\text { ampere. } \\
0.31 \\
.30 \\
.30 \\
.29 \\
.25\end{array}$ \\
\hline
\end{tabular}

The current was found to vary, of course, with the resistance of the circuit. As it continued to flow reduction ensued at the cathode and oxidation at the anode, thereby equalizing the differences and slowly lowering the potential and current. It was not thought necessary to extend the readings further, as the availability of the combination to furnish a noteworthy current was shown. Electrodes of pyrito were then substituted for the platinum. The external resistances were lowered to bring down the total again to $3,000 \mathrm{ohms}$, when the following results were noted:

Oxidation and reduction current with electrodes of pyrite.

\begin{tabular}{|c|c|c|}
\hline Time. & $\begin{array}{l}\text { Effective } \\
\text { electromo- } \\
\text { tive force. }\end{array}$ & Current. \\
\hline $\begin{array}{c}\text { Minutes. } \\
0.1 \\
1.0 \\
5.0 \\
10.0\end{array}$ & $\begin{array}{l}\text { Volts. } \\
1.04 \\
1.02 \\
1.00 \\
1.00\end{array}$ & $\begin{array}{c}\text { Milli- } \\
\text { ampere. } \\
0.34 \\
.33 \\
.33 \\
.33\end{array}$ \\
\hline
\end{tabular}


It is evident from these results that chemical differences between solutions are capable of producing appreciable currents for some time whether the electrodes are of platinum or of a conducting mineral. The polarization appeared to be a little greater, in fact, with the platinum than with the pyrite. The important point for geologic application is that the chemical differences may be equalized at considerable distances as well as locally by electrolytic action when the proper circuits are present. For the elucidation of other similar combinations of solutions and minerals the following additional experiments were performed, all the solutions being approximately normal:

Currents produced in a circuit of 3,000 ohms resistance by different solutions.

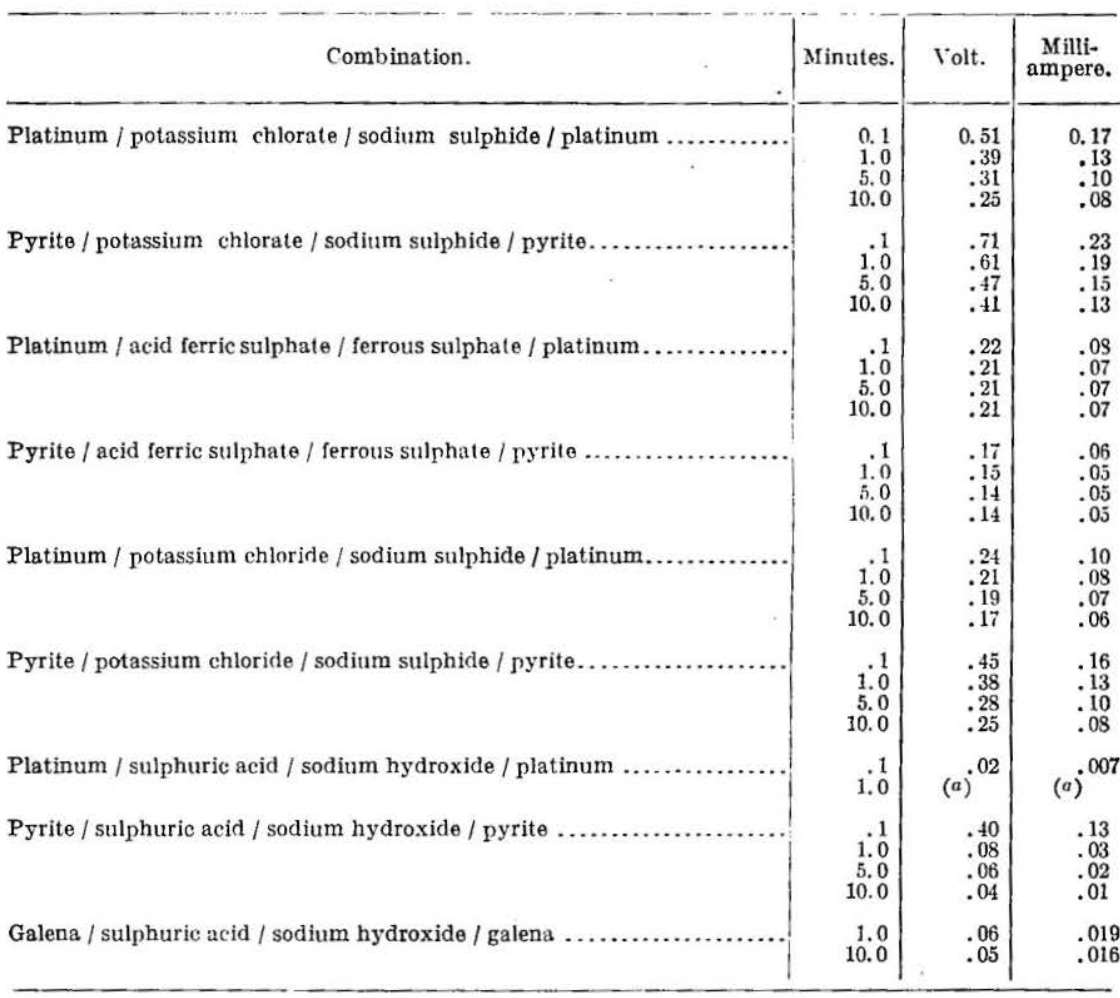

a Negligible.

As the same conductors were used on each side of the above combinations the currents developed must be ascribed to the effect of the solutions. It will be seen, however, that only those solutions which are ordinarily thought to be capable of fairly easy oxidation or reduction furnish noteworthy currents with platinum electrodes. Most other solutions quickly polarize the platinum, leaving only very small 
"residual currents" flowing. Such "residual currents" are ordinarily considered to be due to the fact that the polarizing substances slowly diffuse away from the electrodes while the supply is renewed by the current. With the mineral electrodes the polarization is a little less evident, so that appreciable currents are produced for some time, and with solutions that are also capable of oxidation and reduction the currents may equal or even exceed those produced with platinum electrodes.

In contrast to the preceding results obtained by using different solutions it was found that the currents yielded by different minerals in the same solution are much smaller, being more of the order of "residual currents." In the following experiments the circuit was similar to that above, except that the wick was not used and that the two minerals were dipped into the same solution:

Currents produced by different minerals in the same solution.

\begin{tabular}{|c|c|c|c|}
\hline Combination. & Minutes. & Volt. & $\begin{array}{l}\text { Milli- } \\
\text { ampere. }\end{array}$ \\
\hline Marcasite / potassium chloride / galena.......................... & $\begin{array}{r}0.1 \\
1.0 \\
5.0 \\
10.0\end{array}$ & $\begin{array}{r}0.20 \\
.10 \\
.06 \\
.06\end{array}$ & $\begin{array}{r}0.07 \\
.03 \\
.02 \\
.02\end{array}$ \\
\hline Marcasite / potassium chloride / pyrrhotite....................... & $\begin{array}{l}.1 \\
1.0 \\
5.0\end{array}$ & $\begin{array}{l}.18 \\
.09 \\
.03\end{array}$ & $\begin{array}{l}.08 \\
.04 \\
.013\end{array}$ \\
\hline 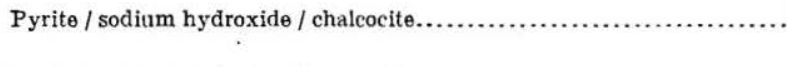 & $\begin{array}{l}1.0 \\
5.0\end{array}$ & $\therefore .02$ & $<.013$ \\
\hline 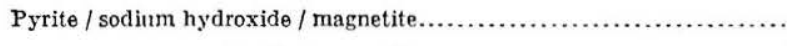 & 1.0 & $<.02$ & $<.01$ \\
\hline Pyrite / potassium chloride / magnetite .................. & 1.0 & $<.02$ & $<.01$ \\
\hline Pyrite / cupric sulphate / galena............ & 1.0 & $<.02$ & $<.01$ \\
\hline Pyrite / potassium chloride / pyrrhotite..... & 1.0 & $<.02$ & $<.01$ \\
\hline
\end{tabular}

Evidently polarization here put a stop to the action in a moment or so, although the potentials on open circuit, as shown on page 10 , might have led one to expect appreciable currents.

In order to proceed further in the elucidation of these phenomena it appeared desirable to reduce the number of variables by considering each electrode separately. It follows from the first results that if a solution is easily oxidizable or reducible no electrode will be quickly polarized. It is also well known that the base metals dissolve as anodes with very little polarization. It therefore seemed the simplest way to set up cells with the various minerals as cathodes and a piece of zinc or copper as anode and record the polarization at the cathode with a given solution. In this way every difference but that of the mineral alone was eliminated. The results in potassium chloride follow. 
Polarization at the cathode.

\begin{tabular}{|c|c|c|c|}
\hline Combination. & Minutes. & Volt. & $\begin{array}{l}\text { Milli- } \\
\text { ampere. }\end{array}$ \\
\hline Pyrolusite / potassium chloride / zinc............ & $\begin{array}{r}0.1 \\
1.0 \\
10.0\end{array}$ & $\begin{array}{l}1.31 \\
1.29 \\
1.17\end{array}$ & $\begin{array}{r}0.45 \\
.44 \\
.40\end{array}$ \\
\hline Chalcocite / potassium chloride / zinc........ & $\begin{aligned} & .1 \\
& 1.0 \\
& 10.0\end{aligned}$ & $\begin{array}{l}.82 \\
.80 \\
.82\end{array}$ & $\begin{array}{l}.37 \\
: 37 \\
.37\end{array}$ \\
\hline Pyrrhotite / potassium chloride / zinc................ & $\begin{array}{r}.1 \\
1.0 \\
10.0\end{array}$ & $\begin{array}{r}.83 \\
.73 \\
.69\end{array}$ & $\begin{array}{l}.27 \\
.24\end{array}$ \\
\hline Marcasite / potassium chloride / zinc.................................. & $\begin{array}{r}.1 \\
1.0 \\
10.0\end{array}$ & $\begin{array}{l}.78 \\
.68 \\
.60\end{array}$ & $\begin{array}{l}.26 \\
.23 \\
.20\end{array}$ \\
\hline Pyrite / potassium chloride / zinc................................. & $\begin{array}{rl}.1 & -1 \\
1.0 & 0 \\
10.0\end{array}$ & $\begin{array}{l}.76 \\
.64 \\
.62\end{array}$ & $\begin{array}{l}.25 \\
.21 \\
.21\end{array}$ \\
\hline Galena / potassium chloride / zinc............... & $\begin{aligned} .1 \\
1.0 \\
10.0\end{aligned}$ & $\begin{array}{l}.61 \\
.55 \\
.48\end{array}$ & $\begin{array}{l}.21 \\
.19 \\
.16\end{array}$ \\
\hline Covellite / potassium chloride / zinc....... & $\begin{aligned} 1.1 \\
1.0 \\
10.0\end{aligned}$ & $\begin{array}{l}.43 \\
.43 \\
.43\end{array}$ & $\begin{array}{l}.14 \\
.14 \\
.14\end{array}$ \\
\hline Platinum / potassium chloride / zinc........... & $\begin{array}{r}.1 \\
1.0 \\
10.0\end{array}$ & $\begin{array}{l}.45 \\
.35 \\
.35\end{array}$ & $\begin{array}{l}15 \\
.12 \\
.12\end{array}$ \\
\hline
\end{tabular}

The minerals have been arranged in the order of increasing polarizability as cathodes. This polarization doubtless depends partly on the solubility of the mineral and possibly also on the rate of solution or diffusion, but whatever may be its cause the experiments indicate an effective difference in action between different minerals. The same intensity was striving to evolve potassium (or hydrogen) in every experiment, but the minerals show different abilities to combine with or remove the hydrogen. The order is roughly that of the effective oxidizing power of the minerals. If the currents had been smaller, the polarization would have been less until, with the limiting condition of no current, the potential would represent exactly the oxidizing intensity of the cathode system. The limiting values would hare theoretical rather than practical value, however, because they would contain no expression of the efficiency or the rate of the action, which is significant for geologic application. Moreover, there are various difficulties in determining the limiting values, among which are the facts that exceedingly small concentrations of certain ions determine the results obtained, that these small concentrations are not reproducible without rigorous exclusion of air, and finally that the minerals themselves often contain impurities. These points will be more fully considered under the headings covering the separate minerals.

The same minerals were polarized by a smaller current-that obtained with copper. The results follow. 
Polarization at the cathode with a copper anode.

\begin{tabular}{|c|c|c|c|}
\hline Combination. & Minutes. & Volt. & $\begin{array}{c}\text { Milli- } \\
\text { ampere. }\end{array}$ \\
\hline Pyrolusite / potassium chloride / copper....... & $\begin{array}{r}0.1 \\
1.0 \\
10.0\end{array}$ & $\begin{array}{r}0.29 \\
.29 \\
.25\end{array}$ & $\begin{array}{r}0.10 \\
.10 \\
.08\end{array}$ \\
\hline Chalcocite / potassium chloride / copper..... & $\begin{array}{r}.1 \\
1.0 \\
10.0\end{array}$ & $\begin{array}{l}.21 \\
.17 \\
.08\end{array}$ & $\begin{array}{l}.07 \\
.05 \\
.03\end{array}$ \\
\hline Marcasite / potassium chloride / copper........................... & $\begin{array}{r}.1 \\
1.0 \\
10.0\end{array}$ & $\begin{array}{l}.29 \\
.08 \\
.06\end{array}$ & $\begin{array}{l}.10 \\
.03 \\
.02\end{array}$ \\
\hline Pyrrhotite / potassium chloride / copper $\ldots \ldots \ldots \ldots \ldots \ldots \ldots \ldots \ldots \ldots \ldots \ldots \ldots \ldots \ldots \ldots \ldots \ldots$ & $\begin{array}{r}.1 \\
1.0 \\
10.0\end{array}$ & $\begin{array}{l}.12 \\
.08 \\
.06\end{array}$ & $\begin{array}{l}.04 \\
.03 \\
.02\end{array}$ \\
\hline Covellite / potassium chloride / copper..... & $\begin{array}{r}.1 \\
1.0 \\
10.0\end{array}$ & $\begin{array}{l}.24 \\
.08 \\
.02\end{array}$ & $\begin{array}{r}.08 \\
.03 \\
<.01\end{array}$ \\
\hline Pyrite / potassium chloride / copper.......... & 10.0 & .04 & .01 \\
\hline Galena / potassium chloride / copper....................... & 1.0 & $(a)$ & (a) \\
\hline Platinum / potassium chloride / copper..$\ldots \ldots \ldots \ldots \ldots \ldots \ldots$ & $\begin{array}{l}1.0 \\
5.0\end{array}$ & $(a)^{.04}$ & ${ }_{(a)} .01$ \\
\hline
\end{tabular}

a Negligible.

The order of polarizability here shown is about the same as before. Pyrolusite is evidently the least polarizable cathode in potassium chloride solution.

Now using pyrolusite as a cathode, other minerals were studied as anodes, with the following results:

Polarization at the anode in potassium chloride solution.

\begin{tabular}{|c|c|c|c|}
\hline Combination. & Minutes. & Volt. & $\begin{array}{l}\text { Milli- } \\
\text { ampere. }\end{array}$ \\
\hline Pyrolusite / potassium chloride / chalcopyrite................... & $\begin{array}{l}0.1 \\
1.0 \\
5.0\end{array}$ & $\begin{array}{r}0.14 \\
.06 \\
.02\end{array}$ & $\begin{array}{r}0.03 \\
.02 \\
.01\end{array}$ \\
\hline 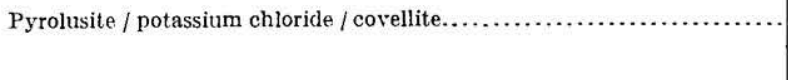 & $\begin{array}{r}.1 \\
1.0 \\
5.0\end{array}$ & $\begin{array}{l}.12 \\
.02 \\
.02\end{array}$ & $\begin{array}{l}.04 \\
.01 \\
.01\end{array}$ \\
\hline 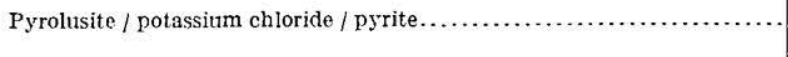 & $\begin{array}{r}.1 \\
1.0\end{array}$ & $\begin{array}{l}.06 \\
.02\end{array}$ & $\begin{array}{l}.02 \\
.01\end{array}$ \\
\hline Pyrolusite / potassium chloride / magnetite ........................... & $\begin{array}{r}.1 \\
1.0\end{array}$ & $\begin{array}{l}.16 \\
.04\end{array}$ & $\begin{array}{l}.05 \\
.013\end{array}$ \\
\hline 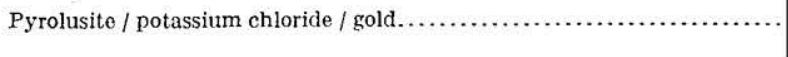 & $\begin{array}{r}.1 \\
1.0\end{array}$ & $\begin{array}{l}.06 \\
.02\end{array}$ & .015 \\
\hline
\end{tabular}

Most of these combinations did not yield sufficient electromotive force to show differences in polarization at the anode. The experiments were therefore repeated with a cathode of slightly higher electromotive force, namely, pyrite / acid ferric sulphate. This was connected to the beaker of potassium chloride by means of a wick, $33477^{\circ}-$ Bull. $548-14-2$ 
the total resistance being $3,000 \mathrm{ohms}$, as in all these experiments. Each cell was of the form-

Pyrite / acid ferric sulphate / potassium chloride / mineral.

The results are tabulated below in the order of increasing polarizability, only the anodes being stated:

Polarization at the anode.

\begin{tabular}{|c|c|c|c|}
\hline Anode. & Minutes. & volt. & $\begin{array}{c}\text { Milli- } \\
\text { ampere. }\end{array}$ \\
\hline Potassium chloride / iron ....... & $\begin{array}{r}0.1 \\
1.0 \\
10.0\end{array}$ & $\begin{array}{r}0.92 \\
.92 \\
.92\end{array}$ & $\begin{array}{r}0.31 \\
.31 \\
.31\end{array}$ \\
\hline Potassium chloride / copper................. & $\begin{array}{r}.1 \\
1.0 \\
10.0\end{array}$ & $\begin{array}{l}.60 \\
.60 \\
.60\end{array}$ & $\begin{array}{l}.20 \\
.20 \\
.20\end{array}$ \\
\hline Potassium chloride / silver....................... & $\begin{array}{r}.1 \\
1.0 \\
10.0\end{array}$ & $\begin{array}{l}.39 \\
.39 \\
.39\end{array}$ & $\begin{array}{l}.13 \\
.13 \\
.13\end{array}$ \\
\hline Potassium chloride / chalcocite ........................ & $\begin{array}{r}.1 \\
1.0 \\
10.0\end{array}$ & $\begin{array}{l}.39 \\
.35 \\
.35\end{array}$ & $\begin{array}{l}.13 \\
.12 \\
.12\end{array}$ \\
\hline Potassium chloride / galena............................... & $\begin{array}{r}.1 \\
1.0 \\
10.0\end{array}$ & $\begin{array}{l}.39 \\
.33 \\
.25\end{array}$ & $\begin{array}{l}.13 \\
.11 \\
.08\end{array}$ \\
\hline 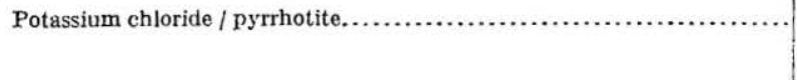 & $\begin{array}{r}.1 \\
1.0 \\
10.0\end{array}$ & $\begin{array}{l}.33 \\
.25 \\
.16\end{array}$ & $\begin{array}{l}.11 \\
.08 \\
.05\end{array}$ \\
\hline Potassium chloride / covellite................... & $\begin{array}{r}.1 \\
1.0 \\
10.0\end{array}$ & $\begin{array}{l}.25 \\
.24 \\
.22\end{array}$ & $\begin{array}{l}.08 \\
.05 \\
.07\end{array}$ \\
\hline Potassium chloride / marcasite.................... & $\begin{array}{r}.1 \\
1.0 \\
10.0\end{array}$ & $\begin{array}{l}.23 \\
.08 \\
.03\end{array}$ & $\begin{array}{r}.08 \\
.03 \\
<.01\end{array}$ \\
\hline Potassium chloride / chalcopyrite...................... & $\begin{array}{r}.1 \\
1.0 \\
10.0\end{array}$ & $\begin{array}{l}.21 \\
.19 \\
.16\end{array}$ & $\begin{array}{l}.07 \\
.06 \\
.05\end{array}$ \\
\hline Potassium chloride / pyrite ................... & $\begin{array}{r}.1 \\
1.0 \\
10.0\end{array}$ & $\begin{array}{l}.19 \\
.14 \\
.06\end{array}$ & $\begin{array}{l}.06 \\
.04 \\
.02\end{array}$ \\
\hline Potassium chloride / magnetite.................... & $\begin{array}{r}.1 \\
1.0 \\
10.0\end{array}$ & $\begin{array}{l}.19 \\
.08 \\
.03\end{array}$ & $\begin{array}{r}.06 \\
.03 \\
<.01\end{array}$ \\
\hline 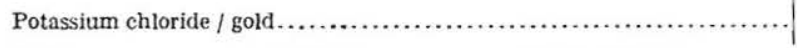 & & (a) & $(a)$ \\
\hline
\end{tabular}

a Negligible.

Here, one may say, the same electromotive force was striving to deposit oxygen on the anode. The order in which the minerals are arranged in the table is therefore the order of their effective reducing power (or of their oxidizability) under the conditions of the experiment. The results show a wide range of polarization. That currents smaller than 0.01 milliampere may be generated for long periods by the less favorable combinations has been proved by several tests. As a current of 0.01 milliampere could deposit 1 milligram of silver a day, it can be seen that even currents so small have geologic significance and that larger currents may produce noteworthy chemical effects, 
But the chief object of the above experiments was to establish the magnitude of the currents actually produced by various combinations as compared with that of currents generated by ordinary galvanic cells. On viewing the results as a whole it is evident that different minerals in the same solution are much less efficient than combinations containing oxidizing and reducing solutions. This difference may probably be ascribed to the fact that the differences in concentration produced by the solution of different minerals are necessarily small, whereas with more soluble salts the concentrations of the effective ions are enormously greater.

\section{ELECTRIC CURRENTS IN THE EARTH.}

In the earth the two electrodes and wire of figure 1 might have their counterpart in a single portion of ore or several ores in contact. The liquid connection might consist of moist rocks or vein solutions. Many possible combinations in the earth's crust might produce electric action. By a judicious use of the imagination it is possible to perceive that this action might affect either fairly large zones or, on the other hand, might contribute to the development and alteration of the most minute particles in tiny veinlets.

In the preliminary measurements of the potential shown by various minerals in various solutions, tabulated and discussed at the beginning of this paper, it was recorded that some of the minerals were appreciably attacked. It may now be stated that there are good reasons to believe that all minerals are attacked by all solutions, but in widely varying degrees. For example, even pyrite, one of the least attackable sulphides, is affected slowly by acidified ferric sulphate. The action results in the production of ferrous salt in the solution, which may proceed both from the reduction of the ferric salt and from the solution of a part of the iron of the pyrite. Experiments have shown that a dilute acid mixture of ferric sulphate and potassium ferricyanide causes the development of an adherent blue precipitate on pyrite, as well as on marcasite, chalcopyrite, and pyrrhotite. That this precipitate adheres in a very thin film seems to be evidence that the minerals function in the reaction.

As pyrite, therefore, is capable of slowly reducing ferric sulphate, it is obvious that any electric action which could arise from the oxidizing power of ferric sulphate would occur chiefly on account of the fact that pyrite enters into direct action very sluggishly - that is, the electric reduction of the ferric solution may occur far more readily under some circumstances than direct reduction by the pyrite. With the more attackable minerals the possibility of electric action would be less than with pyrite, but sufficient experimental evidence has been presented above to show that appreciable currents may be developed by various combinations of solutions and minerals. There 
is always the possibility that electric action may be a more ready way of equalizing chemical differences than direct action. This possibility is in accord with the statement of Becker that it appears to be a law of nature for available energy to be expended as rapidly as possible. Accordingly, chemical energy should be converted into electric energy whenever the attainment of equilibrium would be thereby hastened. Becker has called this a principle of maximum dissipativity. ${ }^{1}$

In addition to the ever-present chemical sources of electric currents in the earth, mention may be made of the fact that sulphides are capable of developing thermoelectromotive forces, a subject which has been investigated by A. Abt, ${ }^{2}$ who gives the following thermoelectric series:

\section{Abt's thermoelectric series.}
1. Chalcopyrite.
2. Pyrolusite.
3. Bismuth.
4. Zinc.
5. Nickel.
6. Copper.
7. Cadmium.

8. Nickel ore.

9. Arc-light carbon.

10. Iron.

11. Pyrrhotite.

12. Antimony.

13. Pyrite.

Diffusion is also capable of developing electric currents and is the cause of potentials between different solutions. These facts are suffcient to justify a study of the behavior of minerals under electric influences.

The fact that appreciable earth currents have seldom been found at any given point does not exclude the possibility that local electric action may be a potent agency in hastening chemical adjustments, or that very small currents acting for long periods would be capable of accomplishing great results. Of course present conditions in the earth are the result of adjustments and readjustments which have been going on for ages. The same forces are available now as always, but ore deposits may represent the result of very long accumulation. It would be incorrect to say that the electric batteries have run down, but, on the other hand, we can hardly expect to find batteries in the field comparable in intensity with those which we can construct in the laboratory. The laboratory results enable us to detect the tendencies at work. Where the action is distributed over a vast distance it appears that even the best experimentation might be unable to detect the action going on.

It will be desirable to discuss separately the several parts of such circuits as those suggested, consisting of various solutions and min-

\footnotetext{
1 Becker, G. F., A new law of thermochemistry: Am. Jour. Sci., 3d ser., vol. 31, p. 120, 1896.

$2 \mathrm{Abt}$, A., Thermoelectromotive force of some metal oxides and metal sulphides in combination with one another and with simple metals with $100^{\circ}$ difference of temperature of the contact points: Annalen der Physik, 4th ser., vol. 2, p. 26i, 1900.
} 
erals. The part requiring the least attention for the present purpose is the liquid connection, for it is well known that solutions of inorganic substances, although varying in conductivity with their nature, concentration, and temperature, are on the whole good conductors of electricity. ${ }^{1}$ One important point, however, must be emphasized. A current in a solution is due to the actual movement of ions through the solution, a subject thoroughly studied by Hittorf as long ago as 1850. The positively charged cations move in one direction, the direction usually called the "current," the negatively charged anions in the opposite direction. It follows from this that wherever electric currents flow in liquid circuits the cations migrate in one direction, the anions in another. For example, an electric current passing up a vein solution would actually consist in the transport of cations upward and of anions downward in the vein solution. Either migration or interchange of ions would also necessarily occur in "local action."

EFFECT OF A CURRENT FROM SOLUTION TO MINERAL.

METHOD OF EXPERIMENT.

A current flowing from a solution to an electrode makes a cathode combination, and according to the well-known principles of electrochemistry, must be accompanied by "reduction." The chief question that arises is whether the reduction affects the constituents of the solution or the mineral forming the electrode. Experiments to determine this point were made in two ways: First, fairly large currents-several hundredths of an ampere-were applied from an outside source; second, more feeble currents were employed-a few milliamperes, such currents as might actually be generated by the combinations already described.

\section{EFFECTS AT THE CATHODE WITH MODERATE CURRENTS.}

Ferric sulphate solution in contact with pyrite was reduced. In dilute sulphuric acid hydrogen and a trace of hydrogen sulphide were evolved. The smooth crystal faces of the pyrite appeared to be irregularly corroded, minute cavities being distributed over their surfaces. Iron was electroplated upon pyrite from a solution of ferrous sulphate, copper from cupric sulphate, silver from silver sulphate, gold from a solution of chlorauric acid, and platinum from a solution of chlorplatinic acid. A piece of pyrite weighing 35 grams was made cathode for five hours in a weak solution of sodium carbonate with a current of 0.04 ampere. The specimen remained bright and lost only 0.0025 gram. Hydrogen was evolved. From caustic soda or sodium sulphide soiutions hydrogen was also evolved, but very little

1 On the conductivity of mine walls and veins see Barus, Carl, U. S. Geol. Survey Mon. 3, p. 345, 1882. The resistances noted were of the order of thousands of ohms. 
or none was evolved from a solution of sodium polysulphide, which suggests that the polysulphide was reduced by the current. With neutral salt solutions, such as those of sodium chloride or sodium sulphate, the solution on electrolysis became alkaline around the cathode.

Marcasite and pyrrhotite behaved much like pyrite as cathodes but were not studied in detail. Galena in sodium sulphate solution suffered some mechanical disintegration along cleavage planes, a fact which suggests that the electric polarization may extend into the minutest capillary spaces. As a result of the action sodium sulphide was formed in the solution. The electrolysis of cathodes of galena in normal sodium hydroxide was stated by Bernfeld to yield one equivalent of metallic lead for each equivalent of sulphur set free or passing into solution. ${ }^{1}$

Magnetite was reduced very slowly if at all in the solutions tried.

Pyrolusite is known to be readily reduced when acting as cathode, its use as depolarizer in the Leclanché cell depending on this fact.

\section{EFFECTS AT THE CATHODE WITH FEEBLE CURRENTS.}

Ferric sulphate in contact with pyrite was reduced. Gold, platinum, silver, and mercury were precipitated from their soluble salts in metallic form on pyrite. The products resulting from sulphuric acid with pyrite, as far as they could be identified, were hydrogen, some hydrogen sulphide, and ferrous sulphate. The pyrite appeared to remain bright and untarnished, however. With sodium chloride and pyrite hydrogen was evolved and the solution became alkaline and showed a trace of soluble sulphide. When cupric sulphate was electrolyzed, if the solution was neutral, some copper was deposited; but under the microscope the copper was seen to shade off into a dark-colored deposit of microscopic cubic crystals which were too small to be identified with certainty. A white precipitate, presumably basic sulphate, was also formed in the solution. No evolution of gas occurred. In a solution that was weakly acid and free from chlorides copper was the first visible product observable on the pyrite. In the presence of chlorides, however, a film consisting of microscopic tetrahedra appeared on the surface of the pyrite, and this film proved to be cuprous chloride.

The time at my disposal has not been sufficient to enable me to make some other experiments of this kind, especially with feeble currents, and the effects obtained might in some experiments differ from the effects produced by larger currents on account of the slow rate at which the very insoluble minerals react with cold solutions.

1 Bernfeld, I., Studien über Schwefelmetallelektroden: Zeitschr. physikal. Chemie, voi. 25, 1. 53, 1898. 
The experiments made indicate that the changes consist principally in a reduction of the constituents of solutions in contact with pyrite. Other possible effects are the deposition of free metals, the formation of hydrogen sulphide, the development of alkalinity, or the evolution of hydrogen or hydrogen sulphide. The sulphides at least are much more resistant as cathodes than as anodes, as will be next shown.

\section{EFFECT OF A CURRENT FROM MINERAL TO SOLUTION.}

When sulphides function as anodes they are attacked much more vigorously than when they function as cathodes. Thus pyrite lost fifty times as much in weight with the same current when anode as when cathode in dilute sodium carbonate solution, and seven times as much in dilute nitric-acid solution. Pyrrhotite lost seven times as much when anode in sodium sulphide solution as when cathorle.

The loss of weight of a pyrite anode in a solution of sodium carbonate, in spite of the fact that it became coated with ferric hydroxide, must have been due to oxidation and solution of the sulphur, which was converted, in part at least, into sulphate, thus showing that both constituents of the pyrite were oxidized. Anodes of pyrite in a solution of sodium sulphide were immediately blackened by ferrous sulphide, which was formed as soon as current was applied. A pyrite anode in a solution of copper sulphate became coated with black iridescent copper sulphide. Under similar conditions with a solution of ferrous sulphate, the anode suffered very little change in weight and extremely slight discoloration, the chief effect of the current consisting in the oxidation of the ferrous sulphate. As compared with its behavior in a solution of sodium sulphide or any other metallic salt the behavior of pyrite in a solution of ferrous sulphate suggests a sort of simultaneous decomposition and regeneration of the pyrite, the net result being hardly noticeable.

In acid solutions no oxygen was evolved on anodes of pyrite with currents of slight intensity. Instead, iron passed into solution as ferric salt. Part of the sulphur was oxidized to sulphate; the rest remained on the anode in the free state. The electrode was noticeably tarnished by films of various shades-gray, purple, and blackthe color changing in the order indicated as the experiment was continued.

In some of these experiments higher potentials were applied than those produced by natural combinations, and the results must be judged accordingly and taken as suggestions of the tendencies at cathode and anode respectively. Further study along this line should be made by those who are interested in special problems likely to be related to the phenomena. 


\section{ELECTRIC CONDUCTIVITY OF MINERALS. .}

Another part of the suggested circuit is formed by the mineral conductors. Fox, whose early study of the electric activity of mineral veins has already been cited, determined that pyrite, arsenical pyrite, galena, pyrolusite, and tetrahedrite are conductors of electricity; that molybdenite is a very imperfect conductor; and that argentite, cinnabar, stibnite, bismuthinite, realgar, and blende are nonconductors. Later observers added other minerals to these categories from time to time.

A very complete list of conducting minerals has recently been compiled by H. A. Wentworth ${ }^{1}$ from a study of their behavior during electrostatic concentration. The theory of electrostatic separation is that fine particles of most substances are attracted toward an electrically charged body, but that only those that are conductive will acquire the same charge and be repelled. If this theory is correct it should be possible to set down a list of the conductive minerals by observing their electrostatic behavior. Wentworth's list is as follows:

Conducting and nonconducting minerals.

Good conductors.

Argentite

Arsenic, native

Arsenopyrite

Bismuth, native

Bismuthinite

Bornite

Brookite

Calaverite

Carborundum

Chalcopyrite

Chalcocite

Cobaltite

Copper, native

Covellite

Enargite

Ferrosilicon

Franklinite

Zinc blende

Quartz

Feldspar

Epidote

\begin{tabular}{|l} 
Galena \\
Graphite \\
Hausmannite \\
Hematite \\
Ilmenite \\
Jamesonite \\
Leucopyrite \\
Linnæite \\
Magnetite \\
Manganite \\
Marcasite \\
Mercury, native \\
Millerite \\
Molybdenite \\
Niccolite \\
Pentlandite \\
Proustite
\end{tabular}

Poor conductors.

Garnet

Apatite

Rutile

\begin{tabular}{|l} 
Psilomelane \\
Pyrargyrite \\
Pyrite \\
Pyrolusite \\
Pyrrhotite \\
Redruthite \\
Silicon \\
Smaltite \\
Sperrylite \\
Stannite \\
Stephanite \\
Sylvanite \\
Tellurium \\
Tetrahedrite \\
Wad \\
Wolframite \\
Zincite
\end{tabular}

Zincite

Nearly all the silicates, carbonates, and sulphates. Most of the siliceous rocks.

1 Wentworth, H. A., Electrostatic concentration or separation of ores: Am. Inst. Min. Eng. Bull. 65, p. 642, 1912. 
The tables of Landolt-Börnstein-Meyerhoffer (1905) give the following values for the conductivities of a few minerals and conducting solids in reciprocal ohms.

Conductivity of minerals in reciprocal ohms.

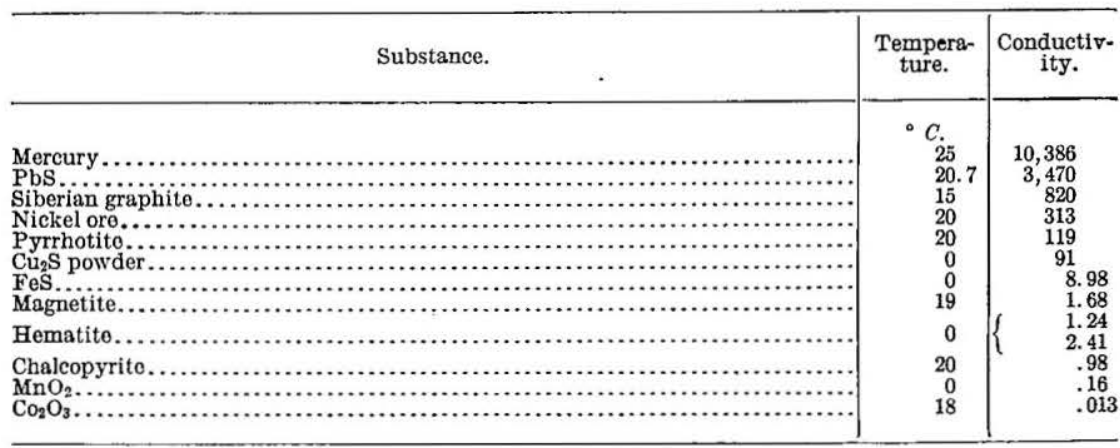

The data in the table are obviously scanty and in part indefinite. Large variations are to be expected on account of inclusions, and small quantities of a second constituent may be sufficient to transform a nonconducting mineral into a fair conductor; sphalerite, for example, seems to possess conductivity by virtue of its content of ferrous sulphide.

It was pointed out by Braun ${ }^{1}$ that the conductivity of some minerals is a function of the direction and time of passage of the current. Dufet ${ }^{2}$ took exception to these conclusions, which were supported later, however, by the work of Bernfeld ${ }^{3}$ on galena.

The conductivity of some sulphides increases with a rise of temperature, as in electrolytic conductors, the behavior of silver sulphide in this respect having been noted by Faraday. The suggestion has been made that the passage of a current in these sulphides causes them to decompose into their elements, but no such decomposition could be observed by Bernfeld with galena. In some experiments heretofore made the contacts used in mounting sulphides for tests have been the chief source of irregularities in their conductivity. ${ }^{5}$ At high temperatures even silicates possess appreciable electric conductivity. It thus appears that a very large number of minerals are susceptible to electric influences.

\footnotetext{
1 Braun, F., Ueber die Stromleitung durch Schwefelmetalle: Poggendorff's Annalen, vol. 153, p. 556, 1874.

2 Dufet, H., Sur la conductibilité électrique de la pyrite: Compt. Rend., vol. 81, p. 628, 1875.

3 Bernfeld, I., Studien über Schwefelmetallelektroden: Zeitschr. physikal. Chemie, vol. 25, p. 50, 1898.

- Poggendorf's Annalen, vol. 31, p. 242, 1834.

$\checkmark$ Hayes, H. V., Note on the electrical conductivity of argentic sulphide: Am. Acad. Arts and Sci. Proc.; vol. 46, p. 613,1910 .
} 


\section{DETAILED STUDY OF VARIOUS POTENTIALS.}

GENERAL RESULTS OF THE MEASUREMENTS.

The object so far has been to establish and exemplify the proposition that electric currents may be generated in the earth and bring about chemical effects. We must now, somewhat more theoretically, consider the relations between electromotive forces and minerals, and must attempt to explain them consistently and point out the conditions under which they are constant and reproducible. In this connection it may be mentioned that measurements of electromotive force are quantitative expressions of physical or chemical differences between different systems-differences made evident by a proper separation of the systems. When the systems are properly separated the tendency toward electric equalization between them may easily be measured. By union or mixture of the systems the differences would generally be equalized without visible electric action.

The most general statement that can be made about the potentials shown by minerals in different solutions is that the potentials are chiefly determined by the solutions. Without denying that there may be specific effects due to the minerals themselves it may be positively stated that the effect produced on the potentials by changing the solutions is enormously greater than the effect of changing the minerals. This is of course due partly to the fact that wide variations in the concentrations of the effective constituents are possible in different solutions.

The very great similarity of all the potentials noted with mineral electrodes to "oxidation and reduction" potentials has already been pointed out. When substances capable of giving such potentials to inert electrodes are present in relatively large amount in a solution in contact with minerals, very constant potentials may generally be developed, but the action of the mineral is then scarcely more than that of an electric conductor, as the amount of oxidizable or reducible material in the solution is so large. Such combinations are not adapted to show differences between minerals, although the data obtained by the experiments may aid in elucidating the chemistry of ores. The following values were obtained with various iron sulphides in a mixture of ferric and ferrous sulphates. The measurements were all made by the usual compensation method of Poggendorff, and the values of the single potentials are referred to the normal calomel electrode without correction for liquid potentials. The minerals, supported by suitable clamps, were partly immersed in the solutions and connection was made to the calomel electrode by a $U$ tube filled with normal potassium chloride. 
Potentials shown by iron sulphides in ferric-ferrous sulphate solutions.

\begin{tabular}{|c|c|c|}
\hline Substance. & Time. & Volt. \\
\hline 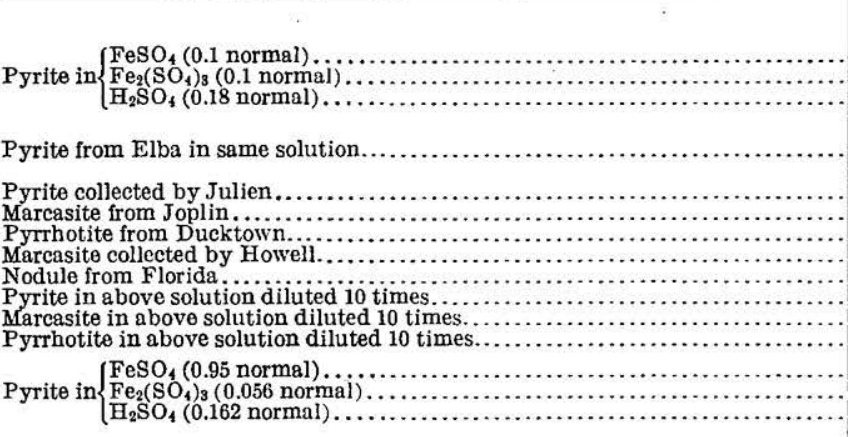 & 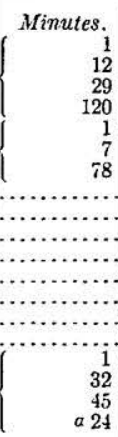 & $\begin{array}{l}0.939 \\
.935 \\
.939 \\
.926 \\
.933 \\
.925 \\
.929 \\
.939 \\
.934 \\
.932 \\
.932 \\
.939 \\
.946 \\
.940 \\
.908 \\
.850 \\
.852 \\
.852 \\
.866\end{array}$ \\
\hline
\end{tabular}

a Hours.

These results show that under the conditions of the experiments the ferric-ferrous potential practically overcame any differences in

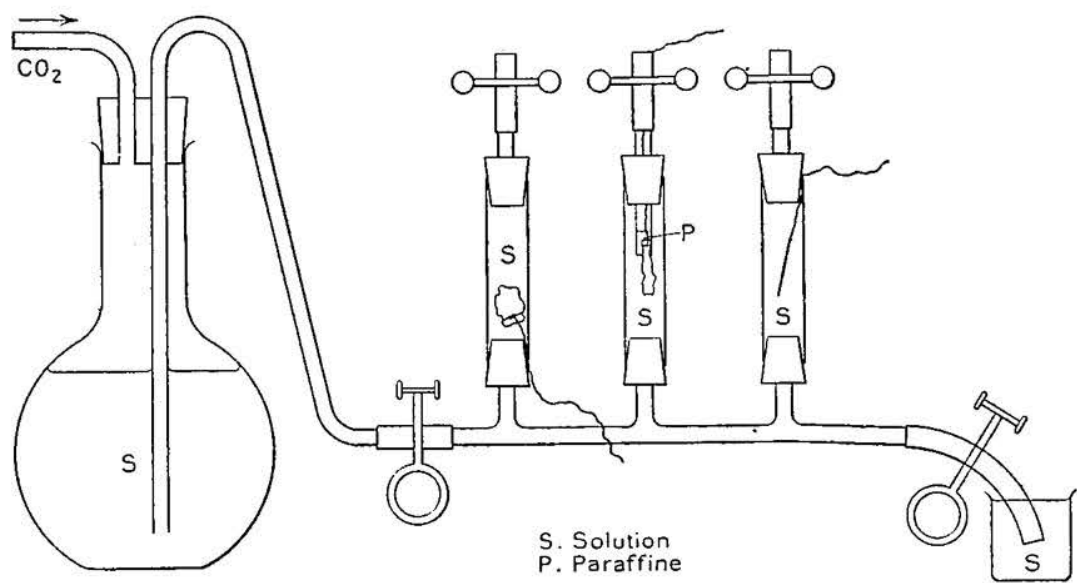

FIGURE 2.-Method of supplying fresh solution to mineral electrodes without affording access of air.

the iron sulphides. In one experiment pyrrhotite gave a lower value, presumably because of the reduction of ferric salt by the hydrogen sulphide formed. That a similar effect occurred to a lesser degree with the other sulphides is at least suggested by the fact that the values are slightly lower than those computed by the equation on page 12, although it is difficult to make a good evaluation of the ionic concentrations in the rather concentrated sulphate solutions. The suggestion that the sulphides slowly reduce ferric sulphate is correct, however, if less concentrated solutions are employed, and, as will be shown later, ferric sulphate is incompatible with most sulphides. 
An effort was made to determine some potentials in a neutral solution of ferrous sulphate wholly free from ferric salt. For this purpose a concentrated solution of ferrous sulphate was prepared and preserved in contact with iron wire in a closed flask fitted with a siphon. An atmosphere of carbon dioxide was maintained in the flask (fig. 2). This solution could be delivered to tubes in which the electrodes were placed. For the sake of comparison a smooth platinum electrode was introduced into a third tube. From time to time fresh solution was allowed to flow over the minerals. At first bubbles of gas appeared on the sulphides, but in the course of time these dissolved. The results are stated in columns headed " $\mathrm{A}$," under the headings "Pyrite" and "Marcasite." To test whether the platinum wires obscured any effect of the sulphides, specimens of the sulphides were attached to platinum wire and the exposed platinum was then wholly covered with paraffin. These specimens gave the results shown in the columns headed "B," under "Pyrite" and "Marcasite," which are practically identical with those shown in the columns headed "A."

Potentials in 3.7 normal ferrous sulphate.

\begin{tabular}{|c|c|c|c|c|c|c|}
\hline \multirow{2}{*}{ Time. } & \multicolumn{2}{|c|}{ Pyrite. } & \multicolumn{2}{|c|}{ Marcasite. } & \multirow{2}{*}{ Platinum. } & \multirow{2}{*}{ Galena. } \\
\hline & $A$ & B & $A$ & B & & \\
\hline 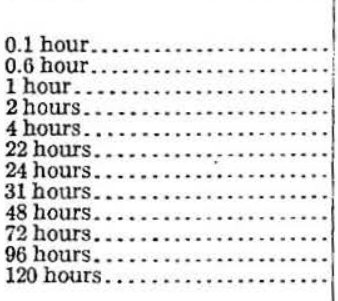 & $\begin{array}{r}\text { Volt. } \\
0.52 \\
.48 \\
.61 \\
.57 \\
.58 \\
.59 \\
.62 \\
.63 \\
.64 \\
.61 \\
.49 \\
.43\end{array}$ & 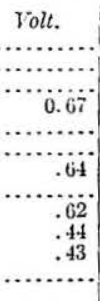 & $\begin{array}{r}\text { Folt. } \\
0.32 \\
.38 \\
.43 \\
.46 \\
.52 \\
.60 \\
.61 \\
.58 \\
.61 \\
.62 \\
.48 \\
.47\end{array}$ & 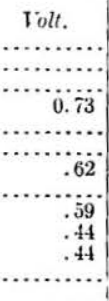 & $\begin{array}{r}\text { Volt. } \\
0.10 \\
.08 \\
.13 \\
.21 \\
.34 \\
.55 \\
.59 \\
.55 \\
.62 \\
.60 \\
.48 \\
.47\end{array}$ & 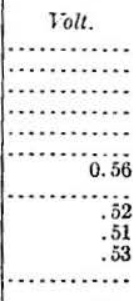 \\
\hline
\end{tabular}

Although no satisfactory explanation of these results can be given, it appears that pyrite, marcasite, and platinum present no significant differences. Evidently such changes as were going on in the solutions were influenced in only a secondary way by the minerals. Galena, however, appeared to maintain a more constant value. The values may possibly be interpreted as ferric-ferrous potentials, in which the concentration of ferric salt was reduced to a constant point.

The following potentials were obtained in normal sodium hydrosulphide saturated with hydrogen sulphide at atmospheric pressure. The specimens were supported in small bottles, as shown in figure 3, the platinum wire being well paraffined and the bottles closed except when measurements were made. 
Potentials in normal sodium hydrosulphide.

\begin{tabular}{|c|c|c|c|c|c|c|}
\hline Time. & Pyrite. & Marcasite. & $\begin{array}{c}\text { Pyrrho- } \\
\text { tite. }\end{array}$ & $\begin{array}{l}\text { Chalcopy- } \\
\text { rite. }\end{array}$ & Galena. & Platinum. \\
\hline 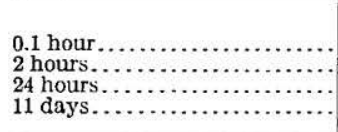 & $\begin{array}{l}\text { Volt. } \\
=0.02 \\
=.01 \\
=.02 \\
-.03\end{array}$ & $\begin{array}{l}\text { Volt. } \\
-0.03 \\
=.03 \\
=.03 \\
=.03\end{array}$ & $\begin{array}{l}\text { Volt. } \\
=0.02 \\
=.03 \\
=.03 \\
-.04\end{array}$ & $\begin{array}{l}\text { Volt. } \\
\because .02 \\
-.02 \\
-.03 \\
\end{array}$ & $\begin{array}{l}\text { Volt. } \\
=0.04 \\
=.04 \\
=.03 \\
=.03\end{array}$ & $\begin{array}{l}\text { Volt. } \\
\quad=0.01 \\
=.04 \\
-.02\end{array}$ \\
\hline
\end{tabular}

To assume that the small differences here shown should be ascribed to differences in the respective minerals would be unwarranted. Rather it appesrs that the minerals, as well as platinum, merely served as conductors for the attainment of a fairly constant potential of the sodium hydrosulphide. Under these conditions, although the minerals are in a polarized state, there is little, if any, indication that one mineral is more stable than another. Electric activity under these circumstances would affect chiefly the solution rather than the minerals.

Many attempts were made to obtain characteristic potentials of the different minerals in the absence of such pronounced oxidizing and reducing solutions as those above mentioned.

The only positive results obtained at first were that one group of sulphides, including pyrite, marcasite, and chalcopyrite, gave potentials higher by one or two tenths of a volt than another group which included pyrrhotite and galena. None of the specimens of sphal-

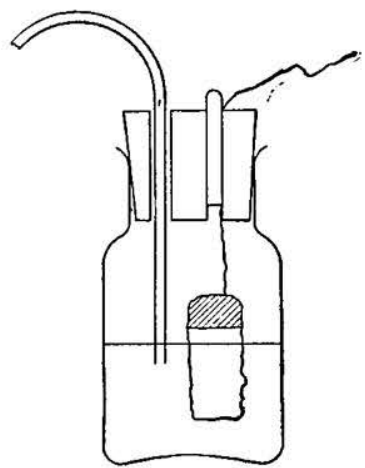

Figure 3.-Half cell of mineral suspended in a solution for observation over a long period. erite examined had enough conductivity to yield a result. In attempting to differentiate pyrite, marcasite, and chalcopyrite it was found that the differences between the minerals were of the same order as the differences between different specimens of the same mineral, and that none of their potentials was much removed from that shown by smooth platinum similarly treated. Of course all minerals have some solubility, so that no matter what other substances there may be in a solution the products resulting from the minerals must also be present. As these products are in general oxidizable or reducible ions, the conclusion is inevitable that the potential of most minerals will be of the nature of an oxidation and reduction potential. We thus return to the thought that even if the minerals have specific potential differences the effect of their solution products on the potential can not be neglected, and this effect may in fact be all there is to the "potential of a mineral" in water. If pure water could be saturated with only the solution products of a pure mineral the problem would be easy, 
but in practice the complete removal of foreign substances from the water and the mineral is extremely difficult if not impossible.

The potential shown by some specimens of a given mineral depends considerably on the previous treatment of the specimens, the explanation of the differences found being that if a mineral is long immersed in a solution some of the solution penetrates its invisible pores and subsequently diffuses out very slowly when the mineral is placed in another solution. When once the pores are filled with water or an indifferent electrolyte the mineral is almost as responsive as a platinum electrode to changes in acidity or concentration of the solution; that is, to such changes as determine the equilibria of the effective ions in the solution.

To what extent observed potentials may be ascribed to minerals, as distinguished from the solutions in contact with them, will best appear, however, from the detailed measurements that follow.

\section{MEASUREMENTS OF POTENTIAL ASSUMED BY CERTAIN MINERALS.}

PYROLUSITE.

Electrodes of manganese dioxide were studied by Tower, ${ }^{1}$ who prepared them by precipitating manganese oxide upon platinum anodes by electrolysis. In order to develop a theory of the potential of the electrode, the solution bathing the electrode was assumed to contain manganous ions. The possible presence of manganese ions of higher valence was apparently not considered by Tower. He proved that the potential of such electrodes depends on the concentration of acid and manganese salt in the solution, the effect of acid being fourfold that of the manganese salt. An increase of acid raises the potential; an increase of manganese salt lowers it. Some of his values are given in the following table:

Potential of manganese dioxide in various solutions at $14^{\circ} \mathrm{C}$. as determined by Tower.

Voits.

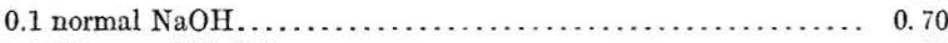

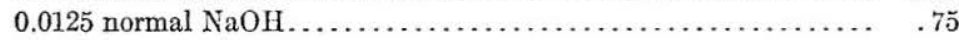

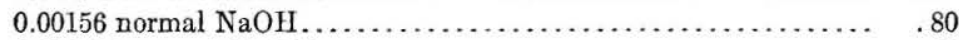

0.000391 normal $\mathrm{NaOH} \ldots \ldots \ldots \ldots \ldots \ldots \ldots \ldots \ldots \ldots \ldots \ldots \ldots \ldots \ldots \ldots \ldots . .84$

Neutral 0.01 normal $\mathrm{Mn}\left(\mathrm{NO}_{3}\right)_{2} \ldots \ldots \ldots \ldots \ldots \ldots \ldots \ldots \ldots \ldots \ldots \ldots \ldots \ldots \ldots \ldots \ldots \ldots . .87$

0.00195 normal $\mathrm{H}_{2} \mathrm{SO}_{4}, 0.2$ normal $\mathrm{Mn}\left(\mathrm{NO}_{3}\right)_{2} \ldots \ldots \ldots \ldots \ldots \ldots \ldots . .4 .4$

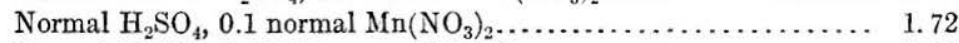

Normal $\mathrm{H}_{2} \mathrm{SO}_{4}, 0.000391$ normal $\mathrm{MnSO}_{4} \ldots \ldots \ldots \ldots \ldots \ldots \ldots \ldots . . .60$

0.000977 normal $\mathrm{H}_{2} \mathrm{SO}_{4}$, normal $\mathrm{MnSO}_{4} \ldots \ldots \ldots \ldots \ldots \ldots \ldots \ldots \ldots \ldots . .44$

0.99 normal $\mathrm{H}_{2} \mathrm{SO}_{4}, 0.000782$ normal $\mathrm{MnSO}_{4} \ldots \ldots \ldots \ldots \ldots \ldots \ldots . . . . . . . .19$

A number of measurements were made by the writer on natural specimens of various oxides of manganese, some of which were said to be pyrolusite and others known to be manganite, but the potentials observed agreed only in part with those recorded by Tower.

1 Tower, O. F., Studien über Superoxyd-Elektroden: Zeitschr. physikal. Chemie, vol. 18, pp. 17-50, 1895. 
The following values were noted with small splinters, said to be pyrolusite, from Germany. Constancy was obtained in from half an hour to an hour.

Potentral of small splinters said to be pyrolusite.

\begin{tabular}{|c|c|c|}
\hline Electrolyte. & 1 & 2 \\
\hline 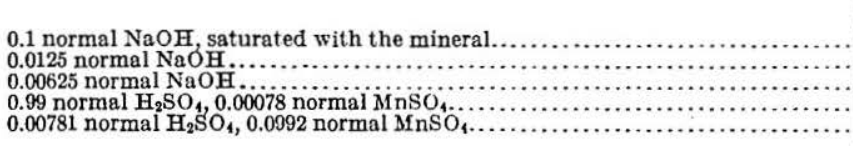 & $\begin{array}{r}\text { Volts. } \\
a 0.52 \\
.74 \\
.72 \\
1.05 \\
1.10\end{array}$ & $\begin{array}{r}\text { Volts. } \\
0.70 \\
.75 \\
.77 \\
1.79 \\
1.54\end{array}$ \\
\hline
\end{tabular}

$a$ Indefinite.

1. Potential obtained by me.

2. Electrolytic $\mathrm{MnO}_{2}$, Tower, O. F., op. cit.

In explanation of these results it should be mentioned that pyrolusite is not a well-crystallized species. The crystalline native manganese dioxide is pollianite, which could not be obtained for study. A massive specimen of pyrolusite from Rio Apache, N. Mex. (U. S. National Museum No. 8424), gave the following potentials:

Potential of massive pyrolusite from Rio A pache, N. Mex.

\begin{tabular}{|c|c|c|}
\hline Electrolyte. & 1 & 2 \\
\hline $\begin{array}{l}0.00781 \text { normal } \mathrm{H}_{2} \mathrm{SO}_{4}, 0.0992 \text { normal } \mathrm{MnSO}_{4} \ldots \ldots \ldots \ldots \ldots \ldots \ldots \ldots \ldots \ldots \ldots \ldots \ldots \ldots \ldots \ldots \ldots \ldots \ldots \ldots \ldots \ldots \ldots \ldots \ldots \ldots \ldots \ldots \ldots \ldots \ldots \ldots \ldots \ldots \ldots \ldots \ldots \ldots \ldots \ldots \ldots \ldots \ldots \\
0.00625 \text { normal }\end{array}$ & $\begin{array}{r}\text { Volts. } \\
1.22 \\
.96\end{array}$ & $\begin{array}{r}\text { Volts. } \\
1.54 \\
.76\end{array}$ \\
\hline
\end{tabular}

1. Potential obtained by the writer.

2. Potential obtained for $\mathrm{MnO}_{2}$ by Tower, op. cit.

This specimen did not come to constancy quickly as did Tower's electrodes on platinum. Another difficulty with this mineral was due to capillarity as manifested in the tendency of the solution to rise up through the mineral and wet the holder.

A very excellent specimen of crystallized manganite from Ilefeld, Hanover, Germany (U. S. National Museum No. 45630), proved to be too nonconducting to permit measurements to be made. Another specimen of the same mineral, however, which had a radiating structure, from Markhamville, Kings County, New Brunswick (U. S. National Museum No. 45711), was sufficiently conducting. When this manganite and the pyrolusite previously mentioned were immersed in the same solution the values shown were as follows:

Potential of manganite and pyrolusite.

\begin{tabular}{|c|c|c|}
\hline Electrolyte. & Manganite. & Pyrolusite. \\
\hline 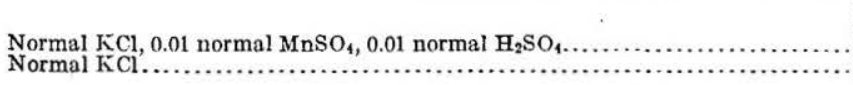 & $\begin{array}{r}\text { Volts. } \\
1.05 \\
.96\end{array}$ & $\begin{array}{l}\text { Volts. } \\
\text { 1. } 33 \\
1.11\end{array}$ \\
\hline
\end{tabular}


The above values are at least in the direction which would be expected-the higher potential for the higher oxide. The potentials obtained in a solution of potassium chloride in the presence of air are the highest observed with any of the minerals investigated and indicate that, when coupled with any other mineral in the presence of air, the manganese mineral would be the cathode; that is, the other mineral would be oxidized by electrolytic action, if it occurred. It was found that pyrolusite is far less easily polarized as cathode than the other minerals studied, a fact which is perfectly consistent with the use of pyrolusite as a depolarizer in the well-known Leclanché battery.

\section{PYRITE.}

The preliminary observations on pyrite showed that its potential is chiefly dependent on the nature of the solution in which it is immersed. In order to determine the effect of changes in the concentration of these solutions the following experiments were performed:

A fresh specimen was immersed in tenth normal, hundredth normal, and thousandth normal sulphuric acid successively, each solution containing about one-fifth of 1 per cent of ferrous sulphate. The three potentials were $0.82,0.83$, and 0.82 volt, respectively, showing at most a very slight dependence on the acid concentration. But with similar variations in the ferrous sulphate content of the solution the potentials were $0.78,0.81$, and 0.84 volt, respectively. The ferrous sulphate solutions each contained a small amount of sulphuric acid. The differences caused by a tenfold change in content of ferrous ion are decidedly greater than those resulting from changes in acidity. Similar results were obtained with ferric sulphate, the potentials being $1.04,1.08$, and 1.11 , respectively. The potentials in even dilute ferric sulphate are strikingly high. These results furnish valuable suggestions for the interpretation of the phenomena. When ferrous and ferric salts are present together we are apparently dealing, in part at least, with a "ferrous-ferric" potential, as was pointed out on page 27.

The potential of pyrite is plainly affected by changes in the hydroxide or sulphide concentration of alkaline solutions, the record presenting a marked contrast to that obtained by changes in acid solutions. The following results show the variation caused by tenfold changes:

Potential of pyrite in alkaline solutions.

\begin{tabular}{|c|c|c|c|}
\hline & Solution. & NaOH. & $\mathrm{Na}_{2} \mathrm{~S}_{\mathbf{x}}$. \\
\hline $\begin{array}{l}\text { Normal.... } \\
0.1 \text { normal. } \\
0.01 \text { normal. } \\
0.001 \text { normal }\end{array}$ & 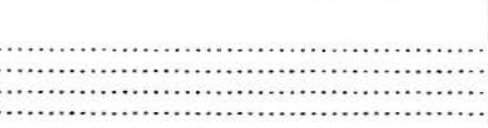 & $\begin{array}{r}\text { Voll. } \\
0.32 \\
.38 \\
.44 \\
.51\end{array}$ & $\begin{array}{l}\text { lioll. } \\
\begin{aligned}-0.07 \\
-.01 \\
+.09 \\
+.15\end{aligned}\end{array}$ \\
\hline
\end{tabular}


Similar effects were noted in solutions of sodium sulphide and sodium hydrosulphide.

The question at once arises whether the hydroxide and sulphide concentrations affect the potential merely by determining the iron content or sulphide content, according to the law of the solubility product or some other similar law, or whether they affect the potential in a direct way; in short, whether pyrite can be considered a "compound electrode." If it can be so considered, the relation between its potential and the concentrations can be expressed by the following equation:

$$
\mathrm{E}=\mathrm{E}_{0}+\frac{\mathrm{RT}}{\mathrm{nF}} \ln [\mathrm{Fe}][\mathrm{S}]^{2} .
$$

There are several difficulties in verifying such an equation. In the first place, with access of air some ferric salt is formed in spite of the presence of the electrode. With the ferric salt present there is the complication of the "ferrous-ferric" potential. Even closed receptacles, boiled solutions, and an atmosphere of carbon dioxide appear to be insufficient to eliminate all ferric salt; enough persists to yield a relatively high potential. Such a potential might also be due to polysulphide ions, which are doubtless formed from pyrite. In an atmosphere of hydrogen it appears that enough normal sulphide is formed to lower the potential appreciably. With even a small concentration of sulphide ion the potential is considerably lowered, but under these conditions a variation of the concentration of ferrous ion (in acid solution) appears to have no effect upon the potential. This was proved by measurements upon marcasite (see below), but the results would probably have been similar for pyrite. The relations of the solubility product of these disulphides are unknown. Lastly, it is very doubtful whether such electrodes can be considered strictly reversible. Whether both atoms of sulphur may function electrically or not has not yet been determined. The presumption is that only one does. When the pyrite is anode there is a very strong tendency toward oxidation of ferrous ion and of sulphur to sulphatethe last action overstepping the limit of reversibility-although as cathode soluble sulphide is formed. Neither set of conditions is wholly favorable for the maintenance of the pyrite. In view of these difficulties any application of the equation must rest upon a good many assumptions and will not be attempted at present. At the same time it is hoped that the potential will some day be expressed by a formula which will be an advance over the present empirical statement of the potential in "water."

For the next experiment, instead of adding any of the constituents of pyrite to the solution, the attempt was made to obtain definite results by letting the pyrite supply its own solution products. If only water $33477^{\circ}-$ Bull. $548-14-3$ 
is used there will be a considerable liquid potential to be reckoned with, and on this account it seemed better to use neutral salt solutions. The following table gives a record of the behavior of pyrite dipping in normal potassium chloride in a small closed bottle (fig. 3 , p. 29) for over a month:

Potential of pyrite in normal potassium chloride in presence of air.

\begin{tabular}{|c|c|c|c|}
\hline Time. & Volt. & Time. & Volt. \\
\hline 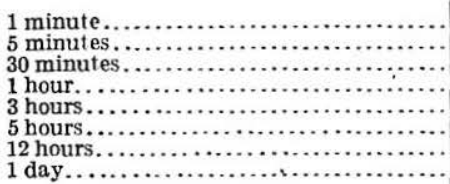 & $\begin{array}{r}0.76 \\
.76 \\
.74 \\
.74 \\
.72 \\
.69 \\
.69 \\
.69\end{array}$ & 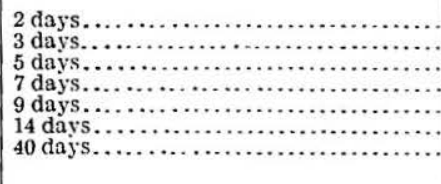 & $\begin{array}{l}0.66 \\
.64 \\
.63 \\
.66 \\
.66 \\
.66 \\
.71\end{array}$ \\
\hline
\end{tabular}

The above results show a slow fall for several hours and thereafter a considerable degree of constancy in the period from 2 to 14 days. Unfortunately, however, other specimens gave different values. Even the same specimen after being dried gave slightly different values at different times when first placed in the solution. The variations thus noted are illustrated by the following results:

Variations of potential in normal potassium chloride duc to accidental causes.

\begin{tabular}{|c|c|c|c|c|}
\hline Date. & 1 & 2 & 3 & 4 \\
\hline 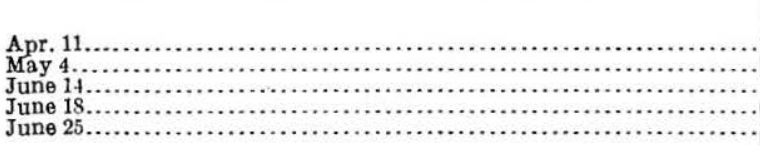 & $\begin{array}{r}\text { Tolt. } \\
1.01 \\
.99 \\
.93 \\
.94 \\
.97\end{array}$ & $\begin{array}{r}\text { Volt. } \\
0.96 \\
.92 \\
.85 \\
.85 \\
1.00\end{array}$ & $\begin{array}{r}\text { Volt. } \\
0.94 \\
.88 \\
.87 \\
.85 \\
.83\end{array}$ & $\begin{array}{r}\text { Volt. } \\
0.72 \\
.71 \\
.68 \\
.83 \\
a .56\end{array}$ \\
\hline
\end{tabular}

a This measurement is evidently erroneous.

1. Pyrite collected by A. A. Julien (No. 39).

2. Pyrite from Elba.

3. Octahedron of pyrite, French Creek, $\mathrm{P}_{0}$

4. Marcasite, cockscomb, collected in Missouri hy C. E. Siehenthal.

In order to see if the presence of air could account for these irregularities a solution of potassium chloride was boiled to free it from air as far as possible. While still warm it was transferred to a flask connected with a siphon, through which it could be delivered to the tubes containing the specimens under investigation. A platinum wire was bound around the specimens and led out between the stoppers and the glass. For the sake of comparison a smooth platinum electrode was introduced into one of the tubes. From time to time fresh solution was allowed to flow over the electrodes. Carbon dioxide from a generator replaced the solution as it was used. The 
apparatus was the same as described on page 27 . The results were as follows:

Potentials of specimens immersed in potassium chloride solution containing $\mathrm{CO}_{2}$ at $25^{\circ} \mathrm{C}$.

\begin{tabular}{|c|c|c|c|c|c|c|}
\hline \multirow{2}{*}{ Time. } & \multicolumn{2}{|c|}{ Pyrite. } & \multicolumn{2}{|c|}{ Marcasite. } & \multirow{2}{*}{ Platinum. } & \multirow{2}{*}{ Galena. } \\
\hline & A. & B. & A. & B. & & \\
\hline 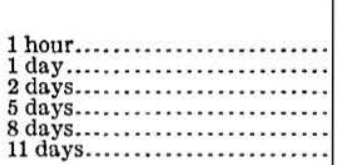 & $\begin{array}{r}\text { Volt. } \\
0.67 \\
.69 \\
.68 \\
.63 \\
.62 \\
.64\end{array}$ & $\begin{array}{r}\text { Volt. } \\
0.66 \\
.65 \\
.71 \\
.59 \\
.61 \\
.62\end{array}$ & $\begin{array}{r}\text { Volt. } \\
0.66 \\
.70 \\
.76 \\
.70 \\
.70 \\
.70\end{array}$ & $\begin{array}{r}\text { Volt. } \\
0.78 \\
.71 \\
.72 \\
.72 \\
.71 \\
.71\end{array}$ & $\begin{array}{r}\text { Volt. } \\
0.62 \\
.60 \\
.56 \\
.65 \\
.65 \\
.60\end{array}$ & $\begin{array}{r}\text { Volt. } \\
0.52 \\
.55 \\
.51 \\
.53 \\
.52 \\
.52\end{array}$ \\
\hline
\end{tabular}

The preceding results suggest that in their electromotive behavior pyrite and marcasite function chiefly as "unattackable electrodes," as their potentials do not vary greatly from those shown by smooth platinum. That the effect was not due to the platinum wires was carefully determined in every experiment by attaching long pieces of several specimens to platinum wires and then completely covering the platinum and a portion of the mineral with paraffin. The results were practically identical with the preceding ones.

The minerals were examined in potassium chloride solution with still greater precautions against the presence of air by the use of tubes in which the solution was boiled out directly, thus avoiding the necessity of transfer (fig. 4). The results of these measurements were as follows:

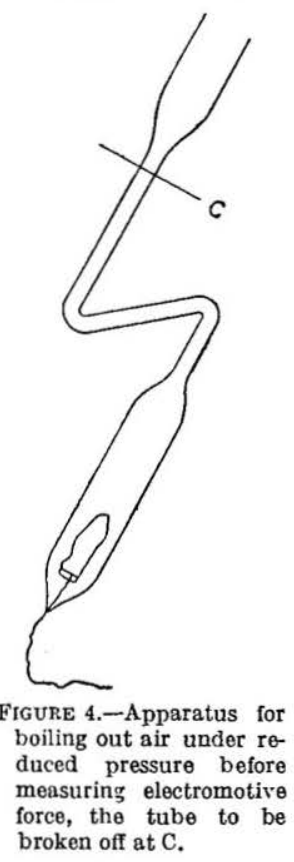

Potentials of specimens immersed in potassium chloride solution boiled out directly.

\begin{tabular}{|c|c|c|c|c|}
\hline Time. & Pyrite. & $\begin{array}{l}\text { Chalcopy- } \\
\text { rite. }\end{array}$ & Marcasite. & Platinum. \\
\hline 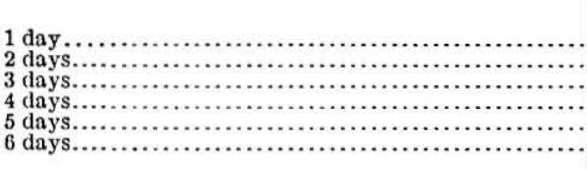 & $\begin{array}{r}\text { Volt. } \\
0.64 \\
.63 \\
.64 \\
.63 \\
.6 .\end{array}$ & $\begin{array}{r}\text { Volt. } \\
0.64 \\
.64 \\
.66 \\
.67 \\
.67 .6 .\end{array}$ & $\begin{array}{r}\text { Volt. } \\
0.60 \\
.60 \\
.60 \\
\cdots \cdots \times . . \% \\
.59\end{array}$ & $\begin{array}{r}\text { Volt. } \\
0.69 \\
.69 \\
.69 \\
.69 \\
\cdots\end{array}$ \\
\hline
\end{tabular}


The conclusion from the preceding experiments is that the exclusior of air lowered the potentials slightly. A much better exclusion of air was finally accomplished, however, by supporting the specimens in a bottle through which a slow current of very pure hydrogen wai carried as long as desired. This brought the potential of pyrit down to values ranging from 0.30 to 0.55 volt according to the lengt of treatment. It seems impossible to avoid the conclusion, therefore that a trace of ferric salt is very persistent unless particular care is used to exclude it or reduce it, and that the potentials in air and ir the absence of air may differ markedly on account of the presence of ferric salt. The unavoidable accidental variations shown bj pyrite in neutral salt solutions are probably due, therefore, to inde terminate traces of ferric salt. The hypothesis that polysulphid, ions are present in varying proportion to sulphide ions is equally plausible and will presently be considered.

Instead of trying to obtain the potential in a neutral solution, a state not easily obtained with reference to the ionization of water, one may reduce the number of variables slightly by measuring the potentials in acid and alkaline solutions of definite concentration and taking the mean value for neutrality. Liquid potentials were largely eliminated by having the solutions about normal with potassium chloride, and as the value 0.83 volt was obtained in tenth-normal sulphuric acid and 0.38 in tenth-normal sodium hydroxide we should obtain 0.60 at the neutral point for the potential of pyrite in normal sodium sulphate solution in the presence of air, assuming the relation to be linear. The values actually obtained in neutral salt solutions under these conditions ranged around 0.72. In hydrogen the two values obtained for tenth-normal solutions were 0.44 and 0.13 volt, respectively, giving a mean of 0.28 volt for the potential of pyrite in a neutral salt solution in the presence of hydrogen.

It was thought that the experiments in hydrogen might have overshot the mark by producing some hydrogen sulphide, and this was found to be the case. Some powdered galena was moistened and placed in a small wash bottle with a glass stopper and the bottle filled with hydrogen. A strip of clean silver suspended in the bottle showed a slight tarnish in a few hours. Evidently, then, hydrogen is too vigorous a reducing agent for the purpose of merely excluding air.

The extreme delicacy of the conditions determining the potential shown by pyrite in normal potassium chloride solution is further illustrated by the ease of its polarization. With a potential of 0.78 volt at the beginning, pyrite was polarized by a very small current, 0.000005 ampere, copper in copper sulphate being used as an auxiliary electrode. The polarizing potential was probably not over 0.3 volt. In 15 minutes the potential of the pyrite had fallen to 0.57 and after- 
ward remained fairly constant at 0.51 . Under these conditions the pyrite was probably surrounded by a film containing very little ferric salt. Upon stopping the polarization the potential rose in half an hour to 0.75 again. The pyrite was then polarized similarly as anode. The potential rose to about 0.97 and remained fairly constant. This probably corresponded to a maximum of ferric salt under the conditions of the experiment. When the polarization was stopped the potential soon fell to 0.80 . With this specimen, therefore, under

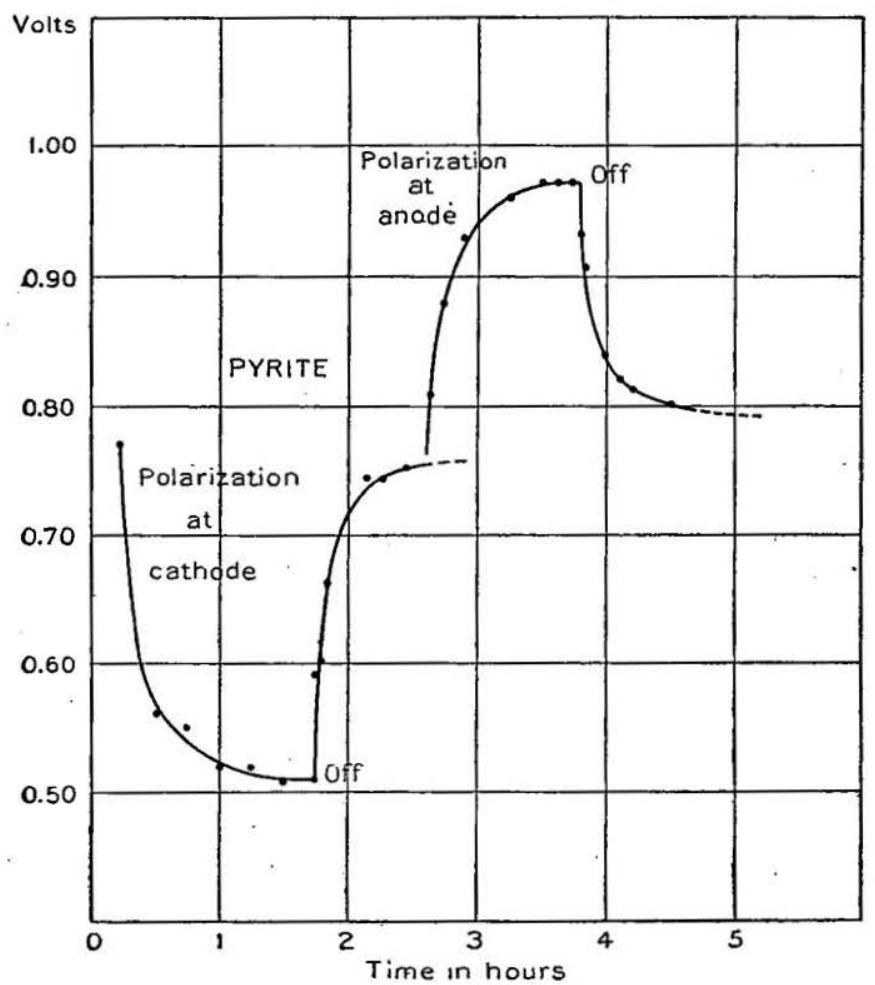

FIGURE 5.-Curves showing rate of polarization. Applied electromotive force about 0.3 volt; current, 0.000005 ampere.

these conditions, the potential certainly lay between 0.75 and 0.80 . The results are shown graphically in figure 5. We are dealing here with a potential which is extremely sensitive to current-that is, the electrode is very easily polarized. In other words, pyrite furnishes so slight a concentration of its characteristic ions that a very feeble current suffices to alter the concentration enormously.

The lag shown by a certain specimen of pyrite in attaining constancy in a new environment is also illustrated by the following results: 
Lag in the potential of pyrite when placed in a new environment.

\begin{tabular}{|c|c|c|}
\hline Substance. & $\begin{array}{l}\text { Time in } \\
\text { hours. }\end{array}$ & $\begin{array}{l}\text { Potential } \\
\text { in volts. }\end{array}$ \\
\hline 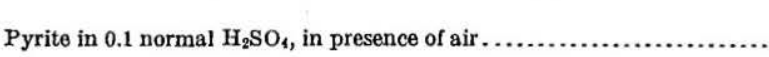 & $\begin{array}{r}0.1 \\
.3\end{array}$ & $\begin{array}{l}+0.87 \\
+.88\end{array}$ \\
\hline 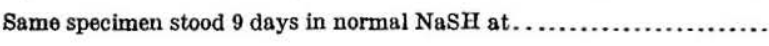 & $\therefore .5$ & \pm .88 \\
\hline Same specimen placed in 0.1 normal $\mathrm{H}_{2} \mathrm{SO}_{4}$, in presence of air......... & $\begin{array}{l}.5 \\
1.0 \\
2.0\end{array}$ & $\begin{array}{l}+.57 \\
+.61 \\
+.65\end{array}$ \\
\hline$\cdot$ & 22.0 & $\begin{array}{l}+.79 \\
+.57\end{array}$ \\
\hline Same specimen placed in 0.1 normal $\mathrm{H}_{2} \mathrm{SO}_{4}$, air displaced by hydrogen.. & $\begin{array}{l}24.0 \\
96.0\end{array}$ & +.44 \\
\hline
\end{tabular}

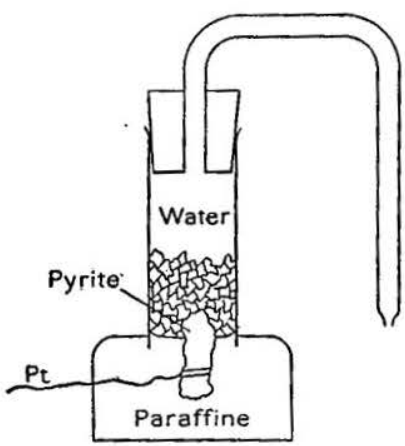

Frgure 6.-Mounting of pyrite to obtain a saturated solution over a long period without access of uir.
The arrangement shown in figure 6 is believed to be the best one devised for mounting pyrite in such a way as to attain its own characteristic potential in water. A good-sized piece of pyrite was attached to a platinum wire and then partly immersed in a block of paraffin. A tube about an inch in diameter was then sunk in the paraffin, forming a water-tight holder. The pyrite in pure water was surrounded with coarsely powdered pyrite for a height of an inch. The potential shown by this pyrite was as follows:

Potential of pyrite in water.

\begin{tabular}{|c|c|c|c|}
\hline Time. & Volt. & Time. & Volt. \\
\hline 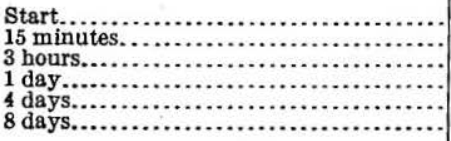 & $\begin{array}{r}0.90 \\
.89 \\
.87 \\
.83 \\
.80 \\
.80\end{array}$ & 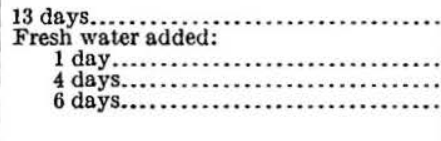 & $\begin{array}{r}0.75 \\
.74 \\
.63 \\
.62\end{array}$ \\
\hline
\end{tabular}

Whatever the solution products of pyrite may be at first, the ions $\mathrm{OH}^{-}$and $\mathrm{SH}^{-}$are probably formed to some extent. It seems reasonable to suppose that these ions will attack the sulphur of the pyrite further, and that the progress of these slow, successive reactions accounts for the slow fall of the potential shown by pyrite in water.

After reviewing all the preceding results, the most logical conclusion concerning the potential shown by pyrite in water with access of air is that its high value is due either to ferric salt, to acid produced by the oxygen of the air, or to polysulphideions. Under these conditions a single electrode of pyrite is incapable of maintaining the iron in the ferrous condition and similarly the sulphide ion is probably oxidized in part, thus assisting in the production of a high potential. Mere traces of ferric ion suffice to give the high value. This explanation is also consistent with the variable results shown by pyrite in a potassium chloride solution. 
When air is excluded, on the other hand, a somewhat lower value is obtained, which seems to vary only slightly with the content of ferrous salt but is extremely sensitive to changes in alkalinity or sulphide concentration and may be reduced to a very low value by an excess of alkali sulphide. These low potentials may be termed "sulphide" potentials. The true potential of the solution products of pyrite must be intermediate between the "ferric-ferrous" potentials and the "sulphide" potentials - that is, must be between 0.80 and 0.56 . If such a thing were possible, it would appear to be a "ferricsulphide" potential. It seems impossible, however, with any arrangement of apparatus so far devised, to establish this potential definitely on account of the slow rate at which the pyrite comes into equilibrium with the solutions, and an expression of the potential in terms of an equation has therefore not been found.

\section{MARCASITE.}

Experiments were made with marcasite to see if it presented any difference from pyrite. The marcasite was in the form of cockscombs, collected in the Joplin district of Missouri by C. E. Siebenthal, of the United States Geological Survey. By the preliminary method of experimentation in air pyrite seemed to give a higher value at first, but marcasite averaged slightly higher after a time. The mean of a number of determinations for marcasite in normal potassium chloride in the presence of air was 0.80 volt, whereas pyrite gave 0.72 volt. Marcasite is ordinarily considered to be more oxidizable than pyrite. In other words, it should produce ferric sulphate faster than pyrite, and this higher potential, attained after the lapse of an hour or so, seems to agree with the interpretation that the high potential of pyrite and marcasite in the presence of air is due to ferric sulphate or sulphuric acid in the solution. According to this interpretation the real factors in the mechanism of the process would be the rate of oxidation and the rate of supply of oxygen.

The variation of the potential of marcasite with changes in alkalinity and in the nature of the solution in general was found to be similar to that shown by pyrite, within the limit of error of the observations. Several of these comparisons have already been given. The following data form an additional record of the phenomena:

Comparison of potentials of marcasite and pyrite.

\begin{tabular}{|c|c|c|}
\hline & Marcasite. & Pyrite. \\
\hline 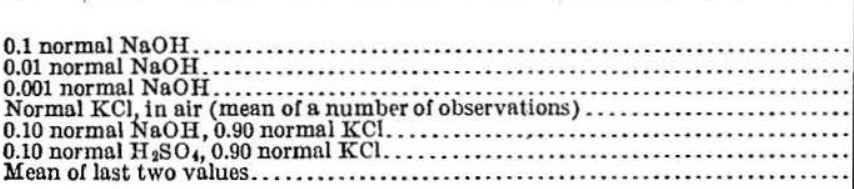 & $\begin{array}{r}\text { Volt. } \\
0.40 \\
.47 \\
.56 \\
.80 \\
.35 \\
.90 \\
.62\end{array}$ & $\begin{array}{r}\text { Volt. } \\
0.38 \\
.44 \\
.51 \\
.72 \\
.38 \\
.83 \\
.60\end{array}$ \\
\hline
\end{tabular}


On the whole the differences here shown between pyrite and marcasite are of the same order as the error of the determinations; nevertheless, the results indicate a persistent tendency of the marcasite toward a slightly higher value in the presence of air. A difference so slight, however, is of a much lower order than the differences caused in the potential by a variation in the nature of the solutions.

Measurements were made in 0.005 normal sulphuric acid in an atmosphere of hydrogen sulphide, the marcasite being partly submerged and suspended by a fine platinum wire. If the dissociation constant $^{1}$ of hydrogen sulphide $[\mathrm{H}]^{2}[\mathrm{~S}]$ is taken as $1.1 \times 10^{-23}$ and the hydrogen ion concentration in 0.005 normal sulphuric $\operatorname{acid}^{2}$ as 0.0043 we should have

$$
\mathrm{S}^{--}=\frac{1.1 \times 10^{-23}}{0.000018}=6.1 \times 10^{-20}
$$

This is certainly not an extreme concentration of sulpbide to try, although it is insufficient to precipitate ordinary ferrous sulphide. The ferrous ion content was varied from 0.0005 molal to 0.1 molal without any effect upon the potential, as the following results show:

Potential shown by marcasite in acid solutions containing potassium chloride and ferrous sulphate and saturated with hydrogen sulphide.

\begin{tabular}{|c|c|c|c|}
\hline $\begin{array}{l}\text { Formula concentra- } \\
\text { tion of } \mathrm{FeSO}_{4} \text {. }\end{array}$ & $\begin{array}{l}\text { Formula concen- } \\
\text { tration of }\left(H^{+}\right) \text {. }\end{array}$ & $\begin{array}{l}\text { Formula concentra- } \\
\text { tion of }\left(\mathrm{S}^{-}\right) \text {. }\end{array}$ & Potential. \\
\hline 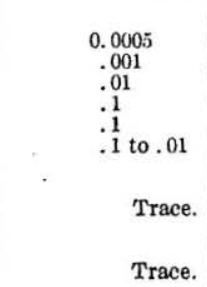 & $\begin{array}{r}0.00+3 \\
.00+3 \\
.00+3 \\
.00+3 \\
.0018 \\
\text { Very little. } \\
\text { Trace. } \\
\text { Trace. }\end{array}$ & $\begin{array}{r}6.1 \times 10^{-20} \\
6.1 \times 10^{-20} \\
6.1 \times 10^{-20} \\
6.1 \times 10^{-20} \\
3.4 \times 10^{-19} \\
\text { Solution satura- } \\
\text { ted with } \mathrm{FeS} \\
\text { and } \mathrm{H}_{2} \mathrm{~S} \text {. } \\
\text { solution saturg- } \\
\text { ted with FeS } \\
\text { and } \mathrm{H}_{2} \mathrm{~S} \text {. } \\
\text { Excess of NaHs. }\end{array}$ & $\begin{array}{r}\text { Volt. } \\
0.292 \\
.292 \\
.297 \\
.294 \\
.291 \\
.269 \\
\\
.261 \\
.120\end{array}$ \\
\hline
\end{tabular}

The above conditions indicated by the table, some sulphur being held in suspension, approach those which are favorable to the development of marcasite. ${ }^{3}$ In the last measurements the acidity was reduced by repeated additions of sodium hydroxide, so that the solution was plainly saturated with ferrous sulphide and with hydrogen sulphide. It was impossible to tell whether or not marcasite was forming on the electrode, which in the acid solution retained its characteristic steel-gray appearance, but in the neutral solution was somewhat blackened by adhering particles of ferrous sulphide.

\footnotetext{
${ }^{1}$ Knox, J., Zur Kenntniss der Ionenbildung des Schwefels und der Komplexionen des Quecksilbers: Zeitschr. Elektrochemie, vol. 12, p. 477, 1906.

2 Drucker, K., Das Dissociationsschema der Schwefelsäure: Zeitschr. Elektrochemie, vol. 17, p. 398, 1911.

8 Allen, E. T., Crenshaw, J. L., and Johnston, J., Mineral sulphides of iron: Am. Jour. Sci., 4th ser., vol. 33 , p. 179, 1912.
} 
The above results bring out the interesting fact that if the solution zontains an excess of soluble sulphide a variation in the concentration of ferrous salt does not affect the potential, but if the concentration of the sulphide is at a minimum higher potentials may be obtained by adding ferric salt, the potential being then determined by the ratio of ferrous to ferric salt.

\section{PYRRHOTITE.}

The pyrrhotite used was collected at Ducktown, Tenn., by F. B. Laney, of the United States Geological Survey. Salt solutions and acids were found to impart a lower potential to pyrrhotite than to pyrite or marcasite. Commercial ferrous sulphide gave a much lower value than pyrrhotite, but it contains metallic iron. According to Richards and Behr, ${ }^{1}$ metallic iron has a potential of -0.17 volt in normal ferrous sulphate.

The following readings were made with electrodes of pyrrhotite:

Potential of pyrrhotite.

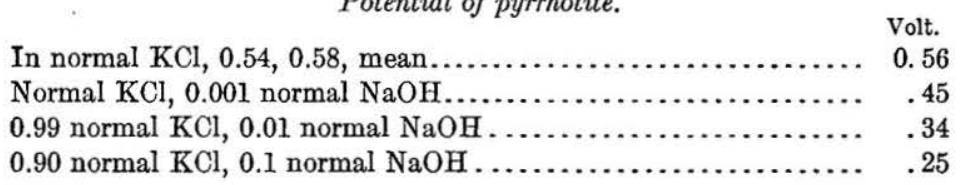

A tenfold change in the quantity of sodium hydroxide in solution produces greater variation in the potential of pyrrhotite than in that of pyrite or marcasite, possibly because free sulphur is easily dissolved from the pyrrhotite by the sodium hydroxide, the result being a low "sulphide" potential. Normal sodium hydroxide gave a very inconstant value with pyrrhotite and appeared to convert it into oxide and soluble sulphide, but normal acid and normal sodium sulphide eventually gave much more constant values.

\section{MAGNETITE.}

The magnetite examined was in the form of large crystals from Mineville, Essex County, N. Y. (U. S. National Museum No. 47830). These crystals were but very slightly fractured. The potentials shown by different crystals in the same solution were rather discordant, although each single potential was very definite. Electrodes of magnetite are very easily polarized and respond quickly to changes in acidity and alkalinity of the solution. Briefly, the mineral behaves very much like an unattackable electrode, but lack of time has so far prevented a sufficiently detailed study to determine whether or not its potential can be correlated with the concentrations of its solution products. The following preliminary values-the

\footnotetext{
1 Richards, T. W., and Behr, G. E., The electromotive force of iron under varying conditions and the effect of occluded hydrogen: Carnegie Inst. Washington Pub. 61, 1907.
} 
averages measured with three different crystals-were obtained in the ordinary way, in the presence of air:

Potential of magnetite.

Volt.

Normal $\mathrm{KCl}$, with access of air . . . .

0.001 normal $\mathrm{NaOH}, 0.99$ normal $\mathrm{KCl} \ldots \ldots \ldots \ldots \ldots \ldots \ldots \ldots . .65$

0.01 normal $\mathrm{NaOH}, 0.99$ normal $\mathrm{KCl} \ldots \ldots \ldots \ldots \ldots \ldots \ldots \ldots \ldots . .62$

0.1 normal $\mathrm{NaOH}, 0.90$ normal $\mathrm{KCl} \ldots \ldots \ldots \ldots \ldots \ldots \ldots \ldots \ldots \ldots \ldots \ldots \ldots \ldots \ldots . .56$

0.1 normal $\mathrm{H}_{2} \mathrm{SO}_{4}, 0.90$ normal $\mathrm{KCl} \ldots \ldots \ldots \ldots \ldots \ldots \ldots \ldots \ldots . .86$

When air is excluded magnetite in contact with water only eventually gives much lower values than those tabulated above. Thus, one specimen mounted in paraffin (fig. 6, p. 38) gave 0.55 volt after 22 days and eventually 0.46 volt.

\section{GALENA.}

Preliminary measurements on galena showed that various solutions alter its potential greatly. Acids do not yield as high values with galena as with pyrolusite, pyrite, or magnetite. In fact, changes in acidity give irregular results, for reasons which will be stated farther on. The potential is not very sensitive to a change in content of lead salt, but is sensitive to changes in alkalinity or concentration of sulphide.

A specimen that gave +0.49 volt in normal potassium chloride fell to 0.24 when hydrogen sulphide was passed into the solution, but rose again to 0.47 after being washed with water and replaced in potassium chloride. The addition of a trace of lead salt gave 0.48 volt.

The effect of excluding air was studied with galena as with pyrite, and it was found that in tenth-normal sulphuric acid the displacement of air by hydrogen resulted in no appreciable change in potential. The most plausible explanation of this fact is that the acid maintains a certain concentration of hydrogen sulphide, which determines the potential both in air and in hydrogen. With pyrite the acid generates so little hydrogen sulphide, if any, that air causes some oxidation of the ferrous salt to ferric. With galena hydrogen sulphide is certainly produced, even in air, so that no further effect of hydrogen would be expected. In an alkaline solution, on the other hand, a difference in potential was noted in the presence and in the absence of air. The value in tenth-normal sodium hydroxide in the presence of air was 0.27 volt and in hydrogen 0.12 . The latter value is practically identical with that shown by pyrite under the same conditions, 0.13. Evidently these values are determined by a certain concentration of sulphide, as hydrogen in a platinum electrode gave -0.48 volt. 
In normal potassium chloride in the presence of air galena gives a lower value than pyrite. The values obtained with different specimens at different times were as follows: $+0.49,0.38,0.53,0.58,0.49$, mean +0.49 volt. Pyrite gave 0.63 volt. When mounted in paraffin (fig. 6, p. 38) so as to exclude air, and in contact with water only, galena gave a potential slightly lower than in air, +0.46 volt, which remained fairly constant over a long period.

Bernfeld gives the following potential measurements for artificial lead sulphide electrodes:

Potential of artificial lead sulphide (Bernfeld).

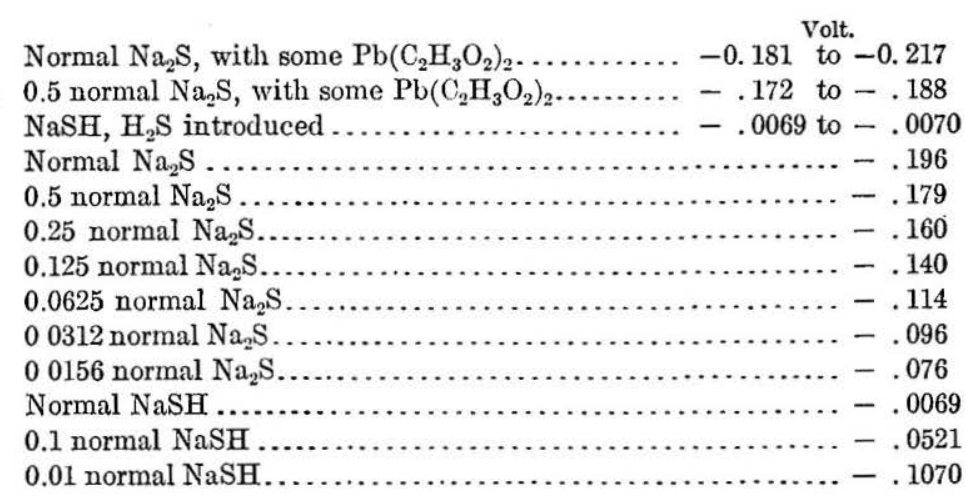

These results are in essential agreement with those shown by natural galena, ranging from -0.19 to -0.24 volt in normal $\mathrm{Na}_{2} \mathrm{~S}$ and -0.03 volt in normal NaSH. The potentials 0.49 volt in potassium chloride with air present or 0.46 volt in water with air excluded appear to be the most characteristic potentials of galena that I have noted, as I have found that potentials in sulphide solutions depend very much on the way the solutions are prepared.

The above results with galena indicate that a variation in the concentration of the lead salt has very little effect on the potential. The latter is greatly affected, however, by the concentration of sulphide. As a matter of fact, galena appears to maintain a fairly constant concentration of sulphide ion on its immediate surface, yielding in salt solutions a potential of 0.49 volt. In the presence of air galena therefore naturally functions as anode against pyrite. In the absence of air its potential may be brought down to low values by soluble sulphides, being then a "sulphide" potential.

Knox ${ }^{1}$ measured the potential of a lead electrode in 0.1 molal $\mathrm{Na}_{2} \mathrm{~S}$. As a mean of seven determinations of the combination

$+\mathrm{Hg} / \mathrm{Hg}_{2} \mathrm{Cl}_{2}$, normal $\mathrm{KCl} /$ normal $\mathrm{KCl} / 0.1$ molal $\mathrm{Na}_{2} \mathrm{~S} / \mathrm{Pb}-$

\footnotetext{
${ }^{1}$ Knox, Joseph, A study of the sulphur anion and complex sulphur anions: Faraday Soc. Trans., vol.4, p. $48,1908$.
} 
he obtained 0.773. Allowing a diffusion potential of 0.010 volt, which is probably better than making no correction at all, we have

$\mathrm{Pb} / 0.1$ molal $\mathrm{Na}_{2} \mathrm{~S}=-0.223$

Inserting this value in the equation

$$
\mathrm{E}=0.129+0.0295 \log \mathrm{C}_{\mathrm{Pb}^{++}}
$$

and solving for $\mathrm{C}$, we find, for $\mathrm{Pb}^{++}$

$$
\mathrm{C}=1.2 \times 10^{-12}
$$

Following Knox and taking the concentration of $\mathrm{S}^{--}$in 0.1 molal $\mathrm{Na}_{2} \mathrm{~S}$ to be $1 \times 10^{-3}$, we have the solubility product $\left[\mathrm{Pb}^{++}\right]\left[\mathrm{S}^{--}\right]=$ $1.2 \times 10^{-15}$ and the concentration of $\mathrm{Pb}^{++}$or $\mathrm{S}^{--}$in a saturated aqueous solution of $\mathrm{PbS}$ at $25^{\circ}=3.4 \times 10^{-8} \mathrm{gm}$. ion per liter and the solubility of $\mathrm{PbS}$ in water at $25^{\circ}$, assuming complete dissociation, would be $=3.4 \times 10^{-8}$ gm.-mole per liter.

SILVER SULPHIDE.

Bernfeld gives the following potential measurements for silver sulphide, $\mathrm{H}_{2} \mathrm{~S}$ having been introduced:

Normal NaSH ................................... -0.178

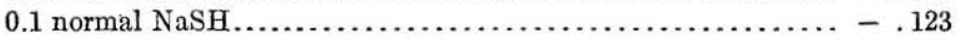

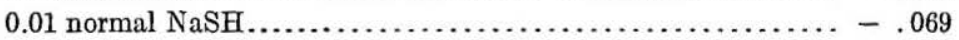

Knox measured the potential of a silver electrode in 0.1 molal $\mathrm{Na}_{2} \mathrm{~S}$. For the combination

$+\mathrm{Hg} / \mathrm{Hg}_{2} \mathrm{Cl}_{2}$, normal $\mathrm{KCl} /$ normal $\mathrm{KCl} / 0.1$ molal $\mathrm{Na}_{2} \mathrm{~S} / \mathrm{Ag}-$ he obtained the value 0.880 . Allowing 0.010 volt for the diffusion potential, as above, we have, for the single potential, the value

$$
\mathrm{Ag} / 0.1 \text { molal } \mathrm{Na}_{2} \mathrm{~S}-0.330
$$

Substituting in the equation

$$
\mathrm{E}=1.06+0.059 \log \mathrm{C}+
$$

we have $\mathrm{C}=4.3 \times 10^{-24}$ for $\mathrm{Ag}^{+}$. The solubility product of $\mathrm{Ag}_{2} \mathrm{~S}$ is therefore

$$
\left(4.3 \times 10^{-24}\right)^{2}\left(1 \times 10^{-3}\right)=1.8 \times 10^{-50}
$$

and in a saturated aqueous solution of $\mathrm{Ag}_{2} \mathrm{~S}$ we should have $\mathrm{Ag}^{+}=$ $3.3 \times 10^{-17}$; or, assuming complete dissociation, the solubility of $\mathrm{Ag}_{2} \mathrm{~S}$ would be $1.6 \times 10^{-17}$ mole per liter at $25^{\circ}$.

\section{BISMUTH SULPHIDE.}

Bernfeld gives the following potential measurements for bismuth trisulphide:

Normal NaSH t gome antimony golution.......................

0.1 normal.

0.01 normal............................................... 


\section{MERCURIC SULPHIDE.}

Behrend gives two measurements on mercuric sulphide, ${ }^{1}$ namely, for mercury in tenth-normal $\mathrm{NaSH},-0.12$, and in tenth-normal $\mathrm{Na}_{2} \mathrm{~S}$, -0.28 , the solution being saturated with the sulphide of mercury. These values are very close to those that I obtained from the soluble sulphides with a smooth platinum electrode, as described on page 47 .

\section{NICKEL AND OTHER SULPHIDES.}

The potentials of several metals in solutions saturated with their sulphides were measured by Zengelis. ${ }^{2}$ It is difficult to determine from his published results the correct sign or even the values of some of the single potentials, but the values stated in the following table are believed to be correct:

Single potentials of metals in solutions saturated with their sulphides, as determined by Zengelis.

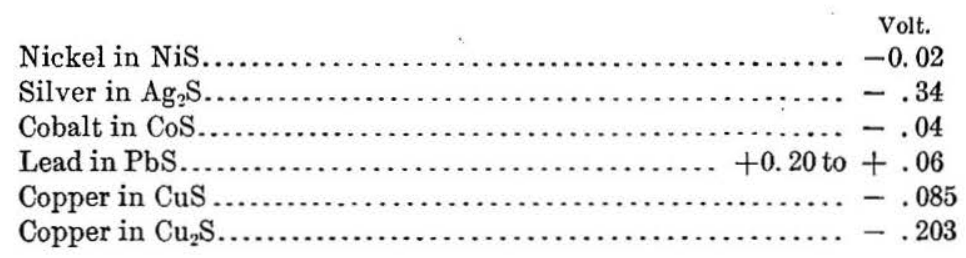

\section{ELECTROMOTIVE BEHAVIOR OF SOLUBLE SULPHIDES.}

REDUCING POWER OF SOLUBLE SULPHIDES.

One of the most characteristic properties of soluble sulphides, aside from their ability to form insoluble precipitates with many metals, is their reducing power. This is shown in the familiar reactions with ferric salts, chromates, ferricyanides, the halogens, the nitro group, nitric acid, and even sulphuric acid. If we consider this property essentially a property of sulphide ions, the reduction of a ferric salt, for example, may be indicated by the equation

$$
2 \mathrm{Fe}^{+++}+\mathrm{S}^{--}=2 \mathrm{Fe}^{++}+\mathrm{S}
$$

According to this equation the sulphide ions give up their negative charges while an equal number of positive charges are neutralized; free sulphur remains; no other ions appear to be directly concerned with the reducing action. The tendency of sulphide ions to give up their charges may also be shown by the production of an electric current as illustrated by the experiments on page 13 . The single

\footnotetext{
1 Behrend, R., Elektrometrische Analyse: Zeitschr. physikal. Chemie, vol. 11, p. 481, 1893.

3 Zengelis, K., Ueber die elektromotorische Kräfte unlöslicher und komplexer Salze: Idem, vol. 12, pp. 298-313, 1893.
} 
potentials created by soluble sulphides under these conditions have been designated sulphide potentials. Since ordinary hydrogen sulphide made from commercial ferrous sulphide contains considerable hydrogen and since in any given solution of acid or alkali a properly prepared platinum electrode saturated with hydrogen should yield a lower potential than a corresponding soluble sulphide, it appeared desirable to ascertain whether hydrogen potentials could be a source of error in measurements of sulphide potentials. With smooth platinum electrodes it was impossible to obtain correct hydrogen potentials in the concentrated sulphide solutions, so that the presence of hydrogen was not considered objectionable, but in the acidified sulphide solutions it was found desirable to avoid hydrogen by preparing hydrogen sulphide from sodium sulphide and hydrochloric acid.

The smooth electrodes used had previously been ignited. It was found that 1 to 4 hours were required for such electrodes to yield constant values in pure sulphide solutions; in the presence of polysulphides, however, constant values were obtained more quickly, and the potentials obtained in the course of 15 to 30 minutes were considered the correct values for such solutions.

On the other hand, the behavior of platinized electrodes was irregular and somewhat uncertain. It was found that well-platinized electrodes which had given correct hydrogen potentials retained a part of the electromotive effect of the hydrogen when placed in solutions of sulphides. It was impossible to obtain correct hydrogen potentials, however, even with the electrodes barely touching the sulphide solutions; when the electrodes were wholly immersed the hydrogen effect was less, but a part of it seemed to be permanent as long as the solutions were saturated with hydrogen. Platinized electrodes appeared to be rendered decidedly less responsive, if not wholly unresponsive, by use in solutions of sulphides. For the reasons noted the use of platinized electrodes seemed highly disadvantageous. The variability of platinized electrodes is shown in the table below:

Effect of hydrogen in platinized electrodes used in sulphide solutions.

\begin{tabular}{|c|c|c|c|c|}
\hline Electrode. & Time. & $\begin{array}{c}\text { Cell } \\
(\mathrm{Hg}+) .\end{array}$ & Platinum. & liemarks. \\
\hline $\begin{array}{l}\text { A freshly platinized electrode, soaked an } \\
\text { hour in hot water, then touching normal } \\
\text { NaOH in bottle. }\end{array}$ & $\begin{array}{r}1.23 \\
1.32 \\
1.37 \\
1.40 \\
3.07 \\
4.00 \\
4.02 \\
4.07 \\
5.00 \\
a 9.00 \\
10.00 \\
10.30 \\
11.00\end{array}$ & $\begin{array}{r}0.12 \\
.13 \\
1.06 \\
1.07 \\
1.07 \\
.96 \\
.90 \\
.88 \\
.86 \\
.88 \\
.80 \\
.79 \\
.80\end{array}$ & $\begin{array}{l}+0.44 \\
+.43 \\
=.50 \\
=.51 \\
=.51 \\
=.40 \\
=.36 \\
=.32 \\
=.30 \\
=.32 \\
=.23 \\
=.24\end{array}$ & $\left\{\begin{array}{l}\text { An oxygen value. } \\
\text { Correct hydrogen value. } \\
\text { A variable intermediate } \\
\text { value. } \\
\text { Correct sulphide potential. }\end{array}\right.$ \\
\hline
\end{tabular}

$a$ Next day. 


\section{RELATION BETWEEN POTENTIAL AND CONCENTRATION.}

In his measurements on oxidation cells Bancroft determined the potential of a fifth molal solution of $\mathrm{Na}_{2} \mathrm{~S}$, which by reference to a normal calomel electrode would yield the single potential $-0.091 .^{1}$ While studying the behavior of polysulphides Küster obtained the value -0.239 for a half molal solution of $\mathrm{Na}_{2} \mathrm{~S} .{ }^{2}$ Only a few other data, most of them incidental, have come to my attention. ${ }^{3}$ Experiments were therefore undertaken to find out, for one thing, how the potential varies with the concentration of sulphide.

For this purpose the potentials of several solutions were measured in half cells made up with submerged smooth platinum electrodes connected to the normal calomel electrode by a normal solution of potassium chloride. The results are stated in the accompanying table:

Potentials of soluble sulphides.

\begin{tabular}{|c|c|c|}
\hline Solution in half cell. & $\begin{array}{l}\text { Potential } \\
\text { of cell } \\
(\mathrm{Hg}+) .\end{array}$ & $\begin{array}{l}\text { Sulphide } \\
\text { potential. }\end{array}$ \\
\hline 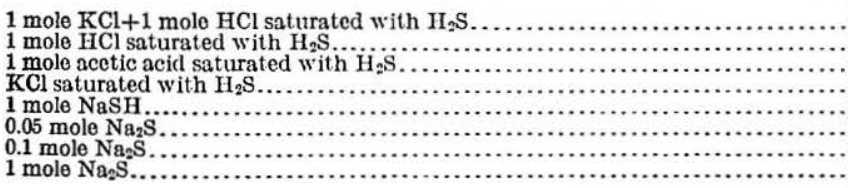 & $\begin{array}{r}0.15 \\
.16 \\
.27 \\
.36 \\
.70 \\
.72 \\
.76 \\
.83\end{array}$ & $\begin{array}{l}+0.41 \\
+.40 \\
+.29 \\
+.20 \\
=.14 \\
=.16 \\
=.20 \\
-.27\end{array}$ \\
\hline
\end{tabular}

When the solutions were to be saturated with hydrogen sulphide the electrodes were supported in the bottles through which the gas was passed, but for $\mathrm{NaSH}$ the excess $\mathrm{H}_{2} \mathrm{~S}$ was expelled with hydrogen. In seeking some relation to express the variation of potential with sulphide concentration a trial was made of the following equation,

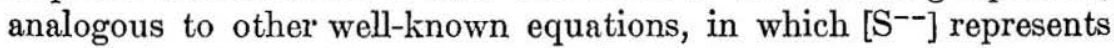
gram-molecules per liter of the sulphide ion:

$$
\mathrm{E}=\mathrm{E}_{0}-0.0295 \log \left[\mathrm{S}^{--}\right]
$$

This equation may apply to an irreversible electrode. Following Knox ${ }^{4}$ we may apply the mass law to the ionization of $\mathrm{H}_{2} \mathrm{~S}$. Since a saturated solution at $25^{\circ}$ is 0.1 molal the expression ${ }^{5}$

reduces to

$$
\mathrm{K}_{1}=\frac{\left[\mathrm{H}^{+}\right]\left[\mathrm{SH}^{-}\right]}{\mathrm{H}_{2} \mathrm{~S}}=0.91 \times 10^{-7}
$$

$$
\left[\mathrm{H}^{+}\right]\left[\mathrm{SH}^{-}\right]=0.9 \times 10^{-8}
$$

1 Bancroft, W. D., Ueber Oxydationsketten: Zcitschr. physikal. Chemie, vol. 10, p. 387, 1892 . See Neumann, Ueber das Potential des Wasserstoff und einiger Metalle: Idem, vol. 14, p. 228, 1894.

2 Küster, F. W., Beitrïge zur Kenntniss der Polysulfide: Zeitschr. anorg. Chemie, vol. 44, p. 445, 1905.

8 Hittorf, W., Zur Kenntniss der elektromotorischen Krïlte galvanischer Kombinationen: Zeitschr. physikal. Chemie, vol. 10 , p. 612,1892 . Two observations yielded -0.10 and -0.04 for 2.77 normal $\mathrm{KSH}$.

' Knox, J., A study of the sulphur anion and of complex sulphur anions: Faraday Soc. Trans., vol. 4, p. 47, 1908; also Zoitschr. Elcktrochemie, vol. 12, p. 477, 1906.

BAuerbach, Zustand des Schwefelwasserstoffs in Mineralquellen: Zeitschr. physikal. Chemie, vol. 49, p. 220,1904 . 
For the secondary ionization Knox gives

$$
\mathrm{K}_{2}=\frac{\left[\mathrm{H}^{+}\right]\left[\mathrm{S}^{--}\right]}{\left[\mathrm{SH}^{-}\right]}=1.2 \times 10^{-15}
$$

whence by combining (I) and (II) we have

$$
\left[\mathrm{S}^{--}\right]=\frac{1.1 \times 10^{-23}}{\left[\mathrm{H}^{+}\right]^{2}}
$$

an expression giving the sulphide ion concentration for any solution of known hydrogen ion concentration. In this way the sulphide ion concentrations of the next table were obtained and from them values of $\mathrm{E}_{0}$ calculated by equation (1).

\begin{tabular}{|c|c|c|c|}
\hline Solution (concentration per liter). & $\begin{array}{l}\text { Sulphide } \\
\text { ion } \\
\text { concentra- } \\
\text { tion. }\end{array}$ & $\underset{\substack{\text { observed } \\
\text { (volt). }}}{\mathbf{E}}$ & $\begin{array}{c}\mathrm{E}^{0} \\
\text { calculated } \\
\text { (volt). }\end{array}$ \\
\hline 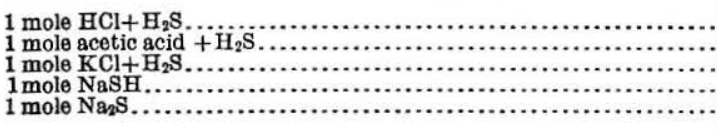 & $\begin{array}{l}1.1 \times 10^{-23} \\
.6 \times 10^{-18} \\
1.2 \times 10^{-15} \\
3.6 \times 10^{-6} \\
.09\end{array}$ & $\begin{array}{l}+0.40 \\
+.29 \\
+.20 \\
+.14 \\
-.27\end{array}$ & $\begin{aligned} & 0.22 \\
= & .24 \\
= & .23 \\
= & .27 \\
= & .30\end{aligned}$ \\
\hline
\end{tabular}

Sulphide potentials observed and calculated by equation (1).

There is a fair approach to constancy in the values of $\mathrm{E}_{0}$, the mean value being -0.26 , so that equation (1) must have some significance in view of the enormous range of the sulphide ion concentration and would appear to be applicable to the determination of sulphide ion concentrations provided polysulphides are absent. The relations shown, however, can not be regarded as a final solution of the problem for $\mathrm{NaSH}$ and $\mathrm{Na}_{2} \mathrm{~S}$, as will appear from what follows.

\section{PREPARATION OF SODIUM HYDROSULPHIDE.}

In preparing sodium hydrosulphide the best substance with which to start is sodium, as recommended by Küster and Heberlein, ${ }^{1}$ but for many purposes sodium hydroxide suffices. If it is desired to avoid oxidized products it is advisable to pass a current of hydrogen through the sodium hydroxide before introducing hydrogen sulphide, and at the same time to have a piece of platinized platinum in the bottle to make the hydrogen more effective through electrolytic action. The saturation of sodium hydroxide with hydrogen sulphide yields a solution containing an excess of hydrogen sulphide. Part of this excess may be removed from a solution as concentrated as

\footnotetext{
1 Küster, F. W., and Heberlein, E., Beiträge zur Kenntniss der Polysulfide: Zeitschr. anorg. Chemie,
} vol. 43 , p. $55,1905$. 
normal by bubbling a stream of hydrogen through the solution for some hours. The changes in the solution from the first introduction of $\mathrm{H}_{2} \mathrm{~S}$ to supersaturation and expulsion of the excess may be followed with advantage by potential measurements. The results of one experiment in which the excess of $\mathrm{H}_{2} \mathrm{~S}$ was neutralized by adding $\mathrm{NaOH}$ from a burette were as follows:

Effect of neutralizing excess $\mathrm{H}_{2} \mathrm{~S}$ in normal $\mathrm{NaSH}$ with $\mathrm{NaOH}$.

\begin{tabular}{|c|c|c|}
\hline $\begin{array}{l}4 \text { normal } \\
\text { NaOH } \\
\text { added. }\end{array}$ & $\begin{array}{l}\text { Potential } \\
\text { of cell. }\end{array}$ & Remarks. \\
\hline $\begin{array}{l}\text { Cc. } \\
0.5 \\
1.0 \\
1.5 \\
2.0 \\
2.5 \\
3.0 \\
3.5 \\
4.0\end{array}$ & $\begin{array}{l}\text { Volt. } \\
0.605 \\
.612 \\
.635 \\
.700 \\
.785 \\
.794 \\
.797 \\
.798\end{array}$ & $\begin{array}{l}\mathrm{H}_{2} \mathrm{~S} \text { in excess. } \\
\text { Solution becomes alkaline to } \\
\text { phenolphthalein. } \\
\text { Solution practically } \mathrm{NaSH} \text {. } \\
\begin{array}{l}\text { About } 16 \text { per cent of } \mathrm{NaSH} \text { now } \\
\text { converted into } \mathrm{Na}_{2} \mathrm{~S} \text {. }\end{array}\end{array}$ \\
\hline
\end{tabular}

It will be observed that the potential changes vary rapidly when the solution has a composition near to $\mathrm{NaSH}$. The value 0.70 for the cell, or the single potential -0.14 , has been selected as the first approximation to the correct potential for a normal solution of the composition NaSH. Such a solution is plainly appreciably hydrolyzed, as is shown by the fact that the solution already becomes alkaline to phenolphthalein at a potential which clearly corresponds to an excess of $\mathrm{H}_{2} \mathrm{~S}$. The above measurements also afford a very clear explanation of the many discrepancies that have been noted in the data of observers working with solutions of $\mathrm{NaSH}$; evidently the acidity has not been definitely regulated.

\section{CHEMISTRY OF THE SULPHIDE ELECTRODE.}

It has been stated that in developing a current the sulphide ions probably give up their charges, leaving free sulphur. This appears to be the primary action. When a feeble current (0.1 milliampere) was passed into a solution of hydrogen sulphide through a platinum anode a white cloud of sulphur was formed on the platinum and in the solution near the platinum; when sodium hydrosulphide or sodium sulphide was employed, however, sulphur was not a visible product nor was any gas evolved, but after a time the solution turned yellow, indicating the formation of a polysulphide. The formation of a polysulphide may be considered a secondary effect due to the solution of sulphur freed by the current in the sodium sulphide present, or it $33477^{\circ}-$ Bull. $548-14-4$ 
may be that polysulphide ions are an oxidation product of sulphide ions, a possibility that will be considered presently.

The pure sulphide electrode appears to be irreversible. When a current is passed in the direction to make the platinum a cathode hydrogen is set free. The likelihood that this hydrogen will not give a proper potential with a smooth electrode has been pointed out. In fact Bose long ago concluded that the saturation of even platinized electrodes is an extraordinarily slow process of diffusion of the gas into the electrode material. There appeared to be no difficulty, however, in attaining the sulphide potential from either side by the compensation method.

To gain light on the action of the reversed current experiments were made to see whether free sulphur in contact with platinum could under any conditions be made to ionize. A solution of sulphur in carbon disulphide was allowed to evaporate from the surface of a platinum electrode, and the electrode, thus coated with numerous crystals of sulphur, was allowed to stand in normal potassium chloride in a closed half cell for a long period. The potentials observed are stated in the first part of the table below:

Potential of platinum coated with sulphur.

\begin{tabular}{|c|c|c|c|}
\hline Solution. & Time. & Cell & $\begin{array}{l}\text { Potential of } \\
\text { platinum. }\end{array}$ \\
\hline 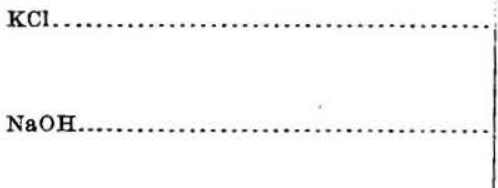 & 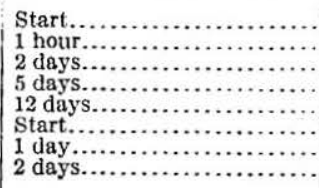 & $\begin{aligned} &(\mathrm{Hg}-) 0.10 \\
& .05 \\
&(\mathrm{Hg}+) .03 \\
& .06 \\
& .11 \\
& .28 \\
& .24 \\
& .44\end{aligned}$ & $\begin{array}{r}+0.66 \\
.61 \\
.53 \\
.50 \\
.45 \\
.28 \\
.32 \\
.12\end{array}$ \\
\hline
\end{tabular}

It seems that the sulphur may be in part the cause of the observed slow fall in potential, but there are so many uncertaintics about the behavior of a piece of platinum in a neutral solution that the results are of questionable significance. They show, however, that the effect, if there is one, is produced very slowly at ordinary temperature.

It is well known that sulphur dissolves in alkali hydroxides at an appreciable speed. ${ }^{1}$ It is not surprising, therefore, that a piece of platinum coated with sulphur as described above and immersed in sodium hydroxide gave a lower potential more quickly, as is shown in the second part of the table above. Of course the production of a soluble sulphide in this way may be regarded as an action that is wholly "chemical" and the electromotive effect as secondary. The experiments are therefore inconclusive as to whether the platinum assisted the ionization of the sulphur at all. 
BEHAVIOR OF POLYSULPHIDES.

The electromotive action of polysulphides is important because they appear to be formed by the electrolytic oxidation of alkali sulphides as well as by the action of sulphur on those salts. Moreover, they may be reduced electrolytically. There appears to be a possibility of arriving at a reversible electrode here. Are polysulphide ions the first direct oxidation product of sulphide ions, rather than sulphur, and are they capable of affecting the electromotive behavior of the sulphide ions?

Küster ${ }^{1}$ measured the potential of several solutions containing polysulphides, and his data are reproduced for reference in the accompanying tables:

Küster's data on polysulphides.

[Cell: $\mathrm{Pt} / \mathrm{NanS}_{\mathbf{x}} /$ normal $\mathrm{KCl} / \mathrm{HgCl} / \mathrm{Hg}+$.]

Solutions saturated with sulphur.

\begin{tabular}{|c|c|c|}
\hline $\begin{array}{c}\text { Formal concen- } \\
\text { tration of Na } \mathrm{S}_{\mathbf{x}} \\
\text { (saturated } \\
\text { with S). }\end{array}$ & $x$ in $\mathrm{Na}_{2} \mathrm{~S}_{\mathbf{x}}$. & Potential of cell. \\
\hline 2 & 4.47 & 0.621 \\
1 & 4.67 & .609 \\
0.5 & 4.84 & .600 \\
.25 & 4.98 & .592 \\
.125 & 5.12 & .584 \\
.062 & 5.22 & .576 \\
.031 & 5.24 & .568 \\
.0155 & 5.20 & .560 \\
.0077 & 5.04 & .552 \\
.0038 & 4.45 & .541 \\
\hline
\end{tabular}

Solutions with varying sulphur content.

\begin{tabular}{|c|c|}
\hline Composition of solution (half formal). & $\begin{array}{l}\text { Potential } \\
\text { of cell. }\end{array}$ \\
\hline 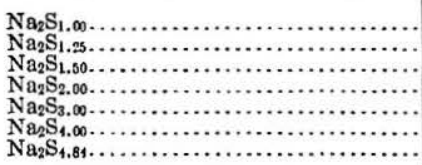 & $\begin{array}{l}0.799 \\
.787 \\
.766 \\
.750 \\
.731 \\
.677 \\
.600\end{array}$ \\
\hline
\end{tabular}

Küster's data were supplemented by measurements of the effect of dilution, given under the next heading.

\section{EFFECT OF DILUTION.}

A few measurements were made on solutions of $\mathrm{Na}_{2} \mathrm{~S}$. The potentials obtained reached constancy very slowly. Solutions containing

1 Küster, F. W., Beitrïge zur Kenntniss der I’olysulnde: Zeitschr. anorg. Chemie, vol. 44, pp. 439, 445. 
some polysulphide gave more easily reproducible values, and measurements of such solutions are shown in the accompanying table:

Effect of dilution on potential of cell.

\begin{tabular}{|c|c|c|c|c|}
\hline $\begin{array}{l}\text { Formal } \\
\text { concentra- } \\
\text { tion. }\end{array}$ & $\mathrm{Na}_{2} \mathrm{~S}$. & $\mathrm{Na}_{2} \mathrm{~S}_{2}$. & $\mathrm{Na}_{2} \mathrm{~S}_{3}$ & $\mathrm{Na}_{2} \mathrm{~S}_{4}$. \\
\hline $\begin{array}{l}2 \\
1 \\
0.5 \\
.25 \\
.125 \\
.062 \\
.031 \\
.015\end{array}$ & $\begin{array}{r}0.851 \\
.828 \\
.803 \\
.783 \\
.760 \\
\ldots . \ldots \ldots \\
\ldots \ldots \ldots\end{array}$ & $\begin{array}{c}(0.785) \\
.768 \\
.752 \\
.734 \\
.718 \\
.700 \\
.682 \\
(.665)\end{array}$ & $\begin{array}{c}0.748 \\
.731 \\
.716 \\
.700 \\
.683 \\
.667 \\
(.650)\end{array}$ & $\begin{array}{c}0.696 \\
.683 \\
.671 \\
.658 \\
.647 \\
.634 \\
(.622)\end{array}$ \\
\hline
\end{tabular}

Apparently the more polysulphide there is present the less marked is the effect of dilution. But the potential of a solution of even the composition $\mathrm{Na}_{2} \mathrm{~S}_{4.7}$ varies somewhat with dilution, and at about 0.015 formal the solution decomposes, with separation of sulphur.

The potential of pure $\mathrm{Na}_{2} \mathrm{~S}$ appears to change by about 0.07 for a tenfold dilution, which is not at once reconcilable with equation (1) (p. 47); that of $\mathrm{Na}_{2} \mathrm{~S}_{4}$ about two-thirds as much. Extrapolating, it would seem that it would require a solution of rather high sulphur content, possibly as high as $\mathrm{Na}_{2} \mathrm{~S}_{6}$, to have a constant potential independent of the dilution. Such a solution can not, however, be prepared.

If we try to resolve such a solution into two components it appears that the simpler one might be as complex as $\mathrm{Na}_{2} \mathrm{~S}_{4}$, which would make the higher one $\mathrm{Na}_{2} \mathrm{~S}_{8}$. The other possible components would be equal amounts of $\mathrm{Na}_{2} \mathrm{~S}_{3}$ and $\mathrm{Na}_{2} \mathrm{~S}_{9}$, or of $\mathrm{Na}_{2} \mathrm{~S}_{2}$ and $\mathrm{Na}_{2} \mathrm{~S}_{10}$, or of $\mathrm{Na}_{2} \mathrm{~S}$ and $\mathrm{Na}_{2} \mathrm{~S}_{11}$, or, lastly, different amounts of two or all of these species. The properties of the higher polysulphides are such, however, that the assumption of much of the species $\mathrm{Na}_{2} \mathrm{~S}$ in them appears unreasonable.

We can gain some light on this perplexing situation by considering the changes in potential when the composition of the solution is varied from $\mathrm{Na}_{2} \mathrm{~S}$ to $\mathrm{Na}_{2} \mathrm{~S}_{\mathbf{x}}$. Measurements were made with this point in view, and some of the results are given in the following table.

In seeking a mathematical elucidation of the results let us, following custom, see if the potential can be expressed as a function of any two molecular species. For the sake of simplicity let us assume that the first oxidation product is disulphide, according to the reaction-

$$
2 \mathrm{~S}^{--}=\left(\mathrm{S}_{2}\right)^{--}+2 \Theta
$$

We should then have a relation for the oxidation-reduction potential like-

$$
\mathrm{E}=\mathrm{E}_{0}+\frac{.059}{2} \log \frac{\left[\mathrm{S}^{--}\right]^{2}}{\left[\left(\mathrm{~S}_{2}\right)^{--}\right]} \ldots \ldots \ldots \ldots
$$


In testing this equation it is only necessary to resolve solutions of compositions between $\mathrm{Na}_{2} \mathrm{~S}$ and $\mathrm{Na}_{2} \mathrm{~S}_{2}$ into the proper mixtures of the two species as shown in the table below and assume that the ionic concentrations are proportional to the molal.

Potential of cell calculated by equation (2).

[Pt / 1.0 molal $\mathrm{Na}_{2} \mathrm{~S}_{\mathbf{x}} / 1.0$ normal $\mathrm{KCl} / \mathrm{HgCl} / \mathrm{Hg}+$.]

\begin{tabular}{|c|c|c|c|c|}
\hline \multirow{2}{*}{$\begin{array}{l}\text { Composi- } \\
\text { tion } x \text { in } \\
\mathrm{Na}_{2} \mathrm{~S}_{x} .\end{array}$} & \multicolumn{2}{|c|}{$\begin{array}{l}\text { Formal concentration } \\
\text { of }-\end{array}$} & \multirow{2}{*}{$\begin{array}{l}\text { Potential } \\
\text { observed. }\end{array}$} & \multirow{2}{*}{$\begin{array}{l}\text { Eo calcu- } \\
\text { Listed by (2). }\end{array}$} \\
\hline & $\mathrm{Na}_{2} \mathrm{~S}$. & $\mathrm{Na}_{2} \mathrm{~S}_{2}$ & & \\
\hline $\begin{array}{l}1.00 \\
1.20 \\
1.40 \\
1.60 \\
1.80 \\
2.00\end{array}$ & $\begin{array}{r}1.00 \\
.80 \\
.60 \\
.40 \\
.20 \\
.00\end{array}$ & $\begin{array}{r}0.00 \\
.20 \\
.40 \\
.60 \\
.80 \\
1.00\end{array}$ & $\begin{array}{r}0.828 \\
.800 \\
.785 \\
.778 \\
.772 \\
.768\end{array}$ & $\begin{array}{r}0.782 \\
.786 \\
.795 \\
.810\end{array}$ \\
\hline
\end{tabular}

As the above table shows, equation (2) does not yield a constant value of $\mathrm{E}_{0}$. In fact, the shape of the potential curve suggests that the second species must be more complex than $\mathrm{Na}_{2} \mathrm{~S}_{2}$. Apparently an excess of sulphur forms at once a higher polysulphide than $\mathrm{Na}_{2} \mathrm{~S}_{2}$. The nearest approach to a uniform slope in the curve falls between $\mathrm{Na}_{2} \mathrm{~S}_{2}$ and $\mathrm{Na}_{2} \mathrm{~S}_{3}$, indicating that if $\mathrm{Na}_{2} \mathrm{~S}$ is one member the other is nearly as complex as $\mathrm{Na}_{2} \mathrm{~S}_{4}$. The electric oxidation would then be

$$
4 \mathrm{~S}^{--}=\left(\mathrm{S}_{4}\right)^{--}+6 \Theta
$$

giving for the potential the expression-

$$
\mathrm{E}=\mathrm{E}_{0}+\frac{.059}{6} \log \frac{\left[\mathrm{S}^{--}\right]^{4}}{\left[\left(\mathrm{~S}_{4}\right)^{--}\right]^{-}}
$$

An evaluation of $\mathrm{E}_{0}$ by this equation is shown in the next table:

\begin{tabular}{|c|c|c|c|c|}
\hline \multirow{2}{*}{$\begin{array}{l}\text { Composi- } \\
\text { tion } x \text { in } \\
\mathrm{Na}_{2} \mathrm{Sx} \text {. }\end{array}$} & \multicolumn{2}{|c|}{$\begin{array}{l}\text { Formal concentration } \\
\text { of }-\end{array}$} & \multirow{2}{*}{$\begin{array}{l}\text { Potential } \\
\text { observed. }\end{array}$} & \multirow{2}{*}{$\begin{array}{l}\text { Eo calcu- } \\
\text { lated by } \\
\text { (3). }\end{array}$} \\
\hline & $\mathrm{Na}_{2} \mathrm{~S}$. & $\mathrm{Na}_{2} \mathrm{~S}_{4}$. & & \\
\hline $\begin{array}{l}1.50 \\
1.75 \\
2.00 \\
2.25 \\
2.50 \\
2.75 \\
3.00 \\
3.25 \\
3.50\end{array}$ & $\begin{array}{r}0.83 \\
.75 \\
.67 \\
.58 \\
.50 \\
.42 \\
.42 \\
.33 \\
.25 \\
.17\end{array}$ & $\begin{array}{r}0.17 \\
.25 \\
.33 \\
.42 \\
.50 \\
.53 \\
.67 \\
.75 \\
.83\end{array}$ & $\begin{array}{r}0.730 \\
.772 \\
.766 \\
.761 \\
.757 \\
.752 \\
.748 \\
.743 \\
.735\end{array}$ & $\begin{array}{r}0.778 \\
.770 \\
.768 \\
.767 \\
.766 \\
.765 \\
.765 \\
.765 \\
.764\end{array}$ \\
\hline
\end{tabular}

Potentials calculated by equation (3).

It will be seen on referring to the table that equation (3) gives a fairly constant value of $\mathrm{E}_{0}$ from $\mathrm{Na}_{2} \mathrm{~S}_{2}$ to $\mathrm{Na}_{2} \mathrm{~S}_{3}$. No equation as complicated as this has to my knowledge been applied to potential meas- 
urements before, although Fredenhagen suggested such equations. ${ }^{1}$ An equation corresponding to the intermediate possibility, namely,

$$
3 \mathrm{~S}^{--}=\left(\mathrm{S}_{3}\right)^{--}+4 \Theta
$$

was found less satisfactory than equation (3).

There is one other possibility-that of writing $\mathrm{NaS}$ instead of $\mathrm{Na}_{2} \mathrm{~S}_{2}$ for the "disulphide," giving the reaction-

$$
\mathrm{S}^{--}=\mathrm{S}^{-}+\ominus
$$

The mathematical test of this possibility showed that it does not fit the facts, except incidentally, for compositions near $\mathrm{Na}_{2} \mathrm{~S}_{1.3}$.

\section{CONCLUSIONS.}

The conclusions from the preceding discussion are then as follows: The electromotive behavior of the polysulphides resembles in a general way that of other reversible oxidation-reduction potentials involving anions. Although it is impossible to account for the behavior without assuming that several species are present in a rather complicated equilibrium, it appears unnecessary to consider $\mathrm{Na}_{2} \mathrm{~S}_{2}$ one of them or possibly even $\mathrm{Na}_{2} \mathrm{~S}_{3}$. The potentials may be calculated as if they depended on the relative concentrations of the two species $\mathrm{Na}_{2} \mathrm{~S}$ and $\mathrm{Na}_{2} \mathrm{~S}_{4}$ for the range from $\mathrm{Na}_{2} \mathrm{~S}_{2}$ to $\mathrm{Na}_{2} \mathrm{~S}_{3}$. On reaching a composition near $\mathrm{Na}_{2} \mathrm{~S}_{4}$ a rapid shift to a much higher sulphide is suggested.

If polysulphides are absent equation (1) on page 47 is somewhat applicable; if they are present equation (3) appears most applicable. Future investigation must discover an expression which will fit the facts for all possible combinations. For acid solutions, however, equation (1) is satisfactory over wide ranges of sulphide ion concentration.

The investigation of the behavior of soluble sulphides has proved very instructive with regard to that of the insoluble sulphides if one can assume that the potentials noted with the insoluble sulphides are due to certain concentrations of sulphide ions or polysulphide ions. For example, the potential of pyrite would certainly be expected to correspond to that of a polysulphide, and its electromotive behavior is entirely consistent with that view, since it gives a higher potential than the monosulphide minerals.

\section{CORRELATION OF THE MEASUREMENTS OF POTENTIAL.}

The study of the potential of various combinations of solutions and minerals has so far merely. opened up a large number of new problems, whose complete elucidation will require further study.

1 Fredenhagen, C., Zur Theorie der Oxydations- und Reductionsketten: Zeitschr. anorg. Chemie, vol. 29 , p. 446, 1902. 
Enough has been done, however, to establish the position of several minerals in the electromotive scale. It has been shown that oxidizing, reducing, acid, and alkaline solutions in contact with minerals impart widely varying potentials to the minerals. Neutral salts, however, have less effect and it seems reasonable to conclude that the potentials shown in neutral salt solutions which are not markedly oxidizing or reducing are practically identical with the potentials that the minerals would assume in pure water-that is, they are due to the solution products of the minerals. The chief sources of error in obtaining such potentials are: The presence of impurities in the minute fractures and pores of the minerals; the fact that the atmospheric environment is not, in general, in equilibrium with the minerals and their solution products; and the extreme slowness with which the very insoluble minerals attain equilibrium with solutions in contact with them.

It is obvious that the ions formed by the solution of most minerals in water fall into the class of easily oxidizable or reducible substances. The mineral potentials are therefore "oxidation and reduction potentials." In order to present a general view of the results of all possible combinations in cells of different types so that the values may be compared, it will be advantageous to assemble in one table the available data showing single potentials. Such a table has been prepared and is presented on page 56 , all potentials being stated on the assumption that the normal calomel electrode has a potential of 0.56 volt. The concentrations are normal unless otherwise stated, except that several values for oxidizing and reducing solutions are taken from Bancroft's data, in which the concentrations were about onefifth normal. An attempt will be made to apply this table to elucidate combinations found in nature.

The table on page 56 shows the oxidizing or reducing potentials of a number of solutions, as well as the positions of solid conductors in the series when these conductors supply their own solution products. It will be noted that the sulphides cover a relatively narrow range, so narrow, in fact, that the potentials which metallic copper might show in solutions of different concentration of copper sulphate would embrace nearly the whole range. It is this fact, coupled with their great insolubility and the slow rate at which they attain equilibrium, that has made an exact determination of the positions of the minerals difficult. The possible usefulness of a new method of presentation, aiming to indicate the direction in which certain chemical reactions will proceed, is the main justification of the table. I am well aware that future study may alter the positions of the minerals slightly if it shall prove possible to refer their electromotive behavior to reversible equilibria. Nevertheless the table shows a natural association 
between certain solutions and minerals, whether one regards the solutions as produced from the minerals or the minerals as produced from the solutions. The principal qualification necessary is the great effect of varying concentration, which can not easily be shown by such a table as that given below. For example, soluble sulphides may impart potentials anywhere from -0.30 to +0.60 , according to their concentration.

Single potentials of solutions and solid electrodes.

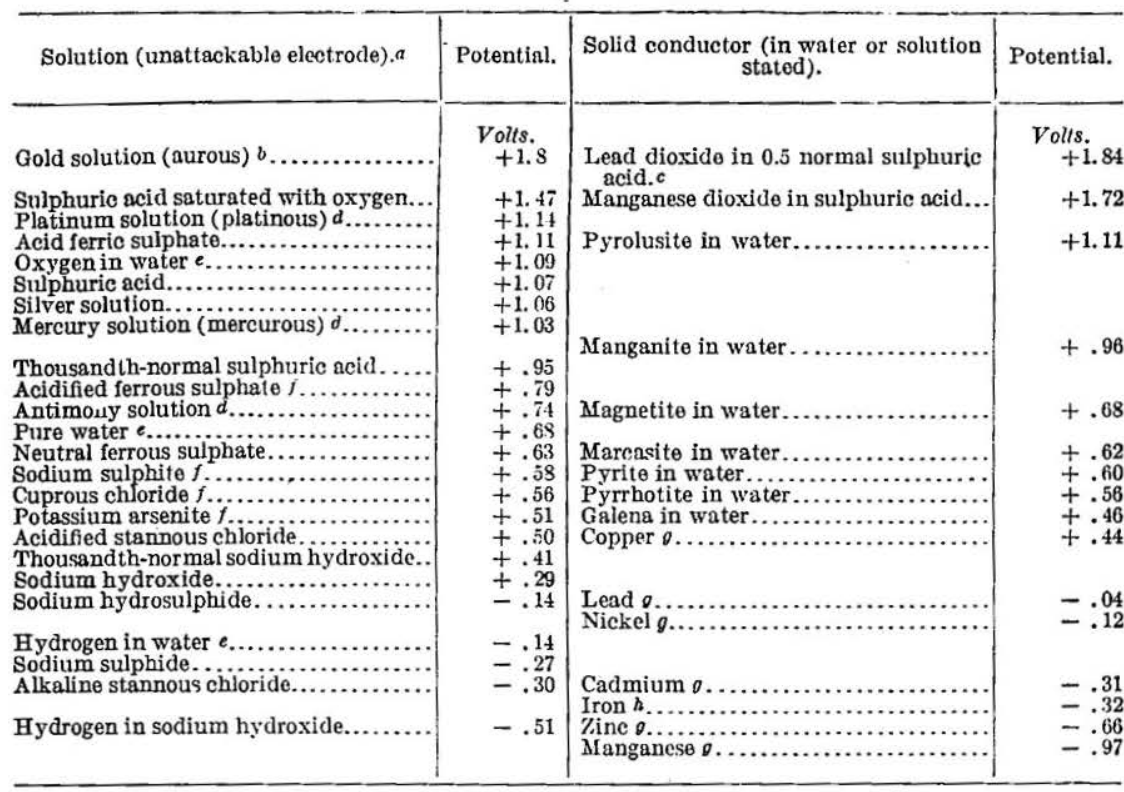

a Under certain conditions minerals may function as unattackable electrodes for many of these solutions, but for hydrogen and oxygen platinized electrodes are essential.

$b$ A begg, Handbuch der anorganischen Chemie, vol. 2, pt. 1, pp. 674, 789, 1908

c Tower, O.F., Studien über Superoxyd-Flektroden: Zeitschr. physikal.'Chemie, vol. 19, pp. 17-50, 1895.

$d$ Wilsmore, N. T., Ueber Elektroden-Potentiale: Idem, vol. 35, p. 31s, 1900. Solution normal with respect to metallic ion.

Calculated as shown on a succeeding page.

$f$ Bancroft, recalculated by Neumann, Ueber das Potential des Wasserstoff und einiger Metalle: Zeitschr. physikal. Chemie, vol. 14, p. 228, 1894.

oThe value stated is the "plertrolytic potential" (Wilsmore) minus $(6 \times 0.029)$, corresponding to a supposed solution of a millionth normal ionic concentration.

$h$ Richards, T. W., and Behr, G. E., The electromotive force of iron under varying conditions and the effect of occluded hydrogen: Carnegie Inst. Washington Pub. 61, 190\%. The value stated is that of Richards and $\mathrm{Behr},-0.15$ volt against normal ferrous sulphate, reduced by $(6 \times 0.029)$, as for the other metals.

It is well known that certain oxidation-reduction potentials depend on the ratio of the concentrations of two ions of higher and lower valence concerned. ${ }^{1}$ But if a single pure reagent is taken in water an adjustment immediately occurs with the other ions present, fixing a concentration of the second member, so that as a rule the potentials of single reagents have a perfectly definite meaning. For

1 See Peters, R., Ueber Oxydations- und Reductionsketten: Zeitschr. physikal. Chemie, vol. 26, p. 201, 1898. 
example, such reactions with ferric and ferrous salts may be represented as follows:

$$
\begin{aligned}
& 4 \mathrm{Fe}^{+++}+4 \mathrm{HO}^{-}=4 \mathrm{Fe}^{++}+\mathrm{O}_{2}+2 \mathrm{H}_{2} \mathrm{O} \\
& 2 \mathrm{Fe}^{++}+2 \mathrm{H}^{+}=2 \mathrm{Fe}^{+++}+\mathrm{H}_{2}
\end{aligned}
$$

Theoretically these reactions must occur and modify the character of the water, although the modification of the water is usually neglected. ${ }^{1}$ Except for this action the potentials of solutions of single pure salts are not reversible. The oxidizing and reducing solutions are perfectly available, however, for furnishing current in one direction, and the potentials thus manifested by solutions of single salts are shown by the table. In view of the above facts all oxidation and reduction potentials might be regarded as due to certain concentrations of oxygen and hydrogen. Such concentrations would of course usually be less than those of saturated solutions; moreover, platinized electrodes are necessary to secure a proper electric action of oxygen and hydrogen, whereas, fortunately, the salts may enter into electromotive action directly.

A very interesting distinction has been brought to light as a result of the study of mineral electrodes. The solution products of many minerals in water are so dilute that their potentials, even with an "unattackable electrode," would correspond to very small concentrations of oxygen or hydrogen. This fact led to the thought that water itself, in the presence of platinum, may be assumed to have certain concentrations of free oxygen and hydrogen in equilibrium with it, and that it would be interesting to calculate the potential which would be shown by hydrogen or oxygen electrodes, with the gases at the pressures possible in pure water. With an ideal inert conductor the hydrogen or oxygen might not need to be at atmospheric pressure in order to establish a definite potential. Such an electrode in pure water should have the potential 0.676 volt. This is calculated as follows:

Lewis ${ }^{2}$ has shown that the electrode [normal $\mathrm{OH}^{-}, \mathrm{O}_{2}$ ] has the value +0.674 volt at $25^{\circ} \mathrm{C}$., and according to Wilsmore the electrode [normal $\mathrm{H}^{+}, \mathrm{H}_{2}$ ] has the value +0.277 volt. We may calculate the potentials which would be obtained in pure water in which the hydrogen and hydroxyl ions have the concentration $1.05 \times 10^{-7}$ by the following equations:

$$
\begin{aligned}
& \mathrm{E}_{\mathrm{O}_{2}}=0.674+0.059 \log \frac{1}{1.05 \times 10^{-7}} \\
& \mathrm{E}_{\mathrm{B}_{2}}=0.277-0.059 \log \frac{1}{1.05 \times 10^{-7}}
\end{aligned}
$$

\footnotetext{
${ }^{1} \mathrm{~A}$ similar modification of water by silver and copper was established by F. Fischer (Zeitschr. physikal. Chemie, vol. 52 , p. 55,1905$)$.

2 Lewis, Q. N., The potential of the oxygen electrode: Am. Chem. Soc. Jour., vol. 28, p. 170, 1906.
} 
This would give +1.087 volt for [water, $\mathrm{O}_{2}$ ] and -0.136 volt for [water, $\mathrm{H}_{2}$ ] both gases being at atmospheric pressure.

In figure 7 the two single potentials 1.087 and -0.136 are indicated by the points $A$ and $C$. We may now calculate the potentials of oxygen and hydrogen electrodes at partial pressures less than one atmosphere by the following equations:

$$
\begin{aligned}
& \mathrm{E}_{\mathrm{O}_{2}}=1.087-\frac{0.0592}{4} \log \frac{1}{\mathrm{p}_{\mathrm{O}_{2}}} \\
& \mathrm{E}_{\mathrm{H}_{2}}=0.136+\frac{0.0592}{2} \log \frac{1}{\mathrm{p}_{\mathrm{H}_{2}}}
\end{aligned}
$$

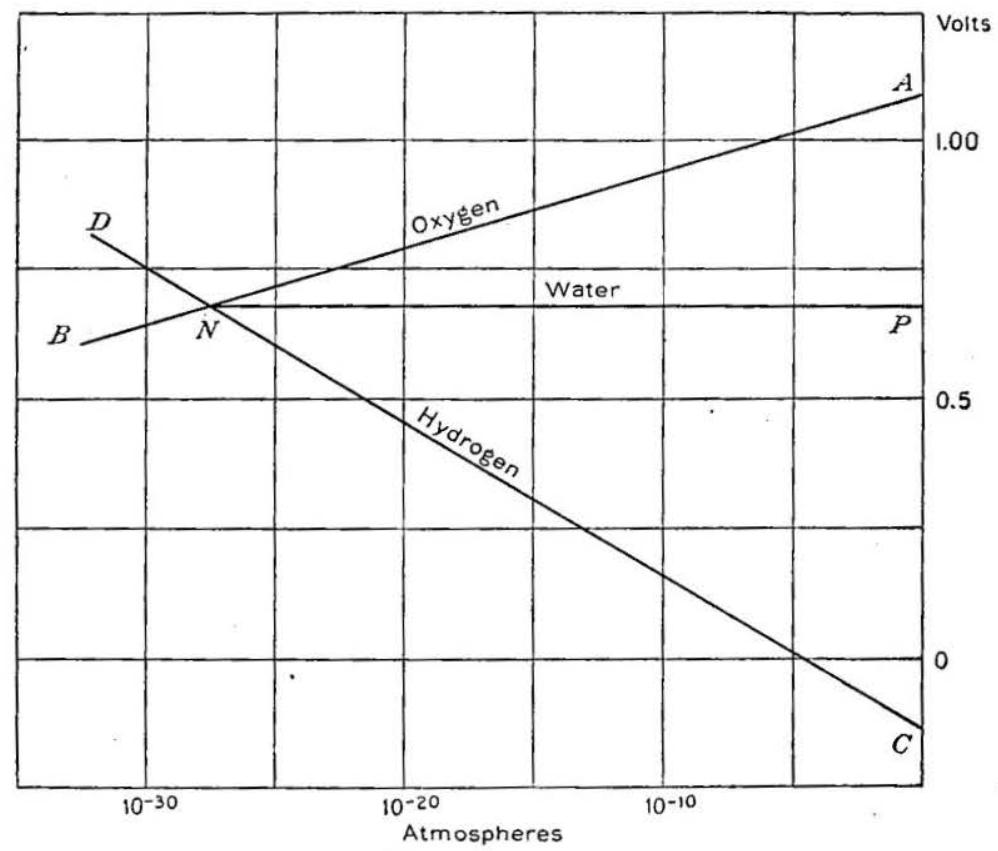

FigURE 7.-Single potentials of oxygen and hydrogen electrodes in water.

If the oxygen is at a lower partial pressure than atmospheric, the potential will be reduced by 0.0148 volt for every tenfold decrease in pressure. This decrease is shown by the line $A B$. With a tenfold decrease in partial pressure the hydrogen potential rises 0.0296 volt, as shown by the line $C D$. At the point $N$ both gases would have the same pressure and the potential, indicated by $P$, would be 0.679 volt.

The potential $P$ is not exactly the potential which we are seeking, since in the purest water conceivable the partial pressure of the hydrogen will be twice that of the oxygen, on account of the dissociation of water into hydrogen and oxygen according to the equation

$$
2 \mathrm{H}_{2} \mathrm{O}=2 \mathrm{H}_{2}+\mathrm{O}_{2}
$$


It is true that the concentrations of hydrogen and oxygen in water are extremely small, but they appear to be related to the oxidizing and reducing power of solutions. The correction on account of the slight difference in the partial pressures of oxygen and hydrogen at pressures so low would reduce the above potential only three or four thousandths of a volt and is therefore almost negligible when compared with the other possible uncertainties in the value. The final corrected potential sought is 0.676 referred to the normal calomel electrode.

If one could imagine an electrode of oxygen at a lower pressure than that corresponding to the point $N$, it would have a lower potential than a hydrogen electrode at the same pressure, and under such conditions water would decompose spontaneously. This decomposition could in fact occur until the partial pressure of the hydrogen became twice that of the oxygen, but no longer, a fact that shows the reasonableness of considering a platinum electrode in a neutral solution at a lower potential than 0.676 a hydrogen electrode, following the line $N C$ instead of $N B$. A lower potential in a neutral solution must correspond to an excess of hydrogen.

Preuner ${ }^{1}$ has calculated the equilibrium constant of the reaction $2 \mathrm{H}_{2}+\mathrm{O}_{2}=2 \mathrm{H}_{2} \mathrm{O}$ at $20^{\circ}$, finding

$$
\frac{\left(\mathrm{H}_{2}\right)^{2}\left(\mathrm{O}_{2}\right)}{\left(\mathrm{H}_{2} \mathrm{O}\right)^{2}}=5.7 \times 10^{-78}
$$

This becomes $1.6 \times 10^{-76}$ at $25^{\circ}$, at which temperature the vapor pressure of water is 0.0031 atmosphere, so that in the presence of liquid water we have

or

$$
\frac{\left(\mathrm{H}_{2}\right)^{2}\left(\mathrm{O}_{2}\right)}{(0.0031)^{2}}=1.6 \times 10^{-76}
$$

$$
\left(\mathrm{H}_{2}\right)^{2}\left(\mathrm{O}_{2}\right)=1.5 \times 10^{-81}
$$

Now in pure water there will still be two volumes of free hydrogen for every volume of free oxygen, so that we may write

whence

$$
\left[2\left(\mathrm{O}_{2}\right)\right]^{2}\left(\mathrm{O}_{2}\right)=1.5 \times 10^{-81}
$$

and

$$
\left(\mathrm{O}_{2}\right)=7.2 \times 10^{-28}
$$

$$
\left(\mathrm{H}_{2}\right)=1.4 \times 10^{-27}
$$

the last two values being the partial pressures of oxygen and hydrogen in pure water.

It is a surprising fact that at the partial pressures of oxygen and hydrogen thus calculated the potentials of the two electrodes would be

\footnotetext{
1 Preuner, G., Ueber die Dissociationskonstante des Wassers und die elektromotorische Kraft des Knallgaskette: Zeitschr. physikal. Chemie, vol. 42, p. 54, 1903.
} 
0.670 and 0.688 , if the calculation is made as usual from the values 1.087 and -0.136 for the two electrodes in water and at atmospheric pressure, with a mean value 0.679 volt.

We now have two values for the potential sought.

From Lewis's and Wilsmore's values when $\mathrm{E}_{\mathrm{O}_{2}}=\mathrm{E}_{\mathrm{E}_{2} \ldots \ldots \ldots} \ldots .676$

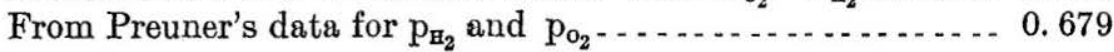

For the present the value 0.676 volt will suffice.

Several interesting distinctions may be drawn in regard to this potential. Bearing in mind the fact that it refers to a neutral solution we obtain a criterion by which we may decide whether a solution contains an excess of oxygen or hydrogen over the amounts necessary to form water. Thus all neutral solutions imparting a higher potential than 0.676 to an unattackable electrode should contain an excess of free oxygen, whereas those giving a lower potential should contain an excess of free hydrogen. The various oxidizing and reducing solutions may contain almost every concentration of free oxygen and hydrogen. Thus waters at the surface of the earth will contain oxygen at a pressure of about one-fifth of an atmosphere. The oxygen in the ground water, however, will be considerably reduced, passing through very small concentrations until at a certain depth, differing according to the geologic structure, there will be practically no excess of oxygen or hydrogen. Below this depth hydrogen will be in excess at concentrations increasing with the depth. The differentiating potential 0.676 will be higher in acid solutions and lower in alkaline solutions, but it is most convenient to discuss its application in neutral solutions. It is a sort of natural zero of potential.

Salts of the metals more noble than copper will behave like oxidizing agents - that is, an indifferent electrode immersed in them will become a cathode with respect to the imaginary electrode of 0.676 volt. Combinations such as water / metal of the metals less noble than copper will act as reducing agents-that is, will function as anodes against the reference electrode. According to the same criterion the mineral sulphides would be feeble reducing agents, although their solution products are probably hydrolyzed slightly, yielding feebly alkaline solutions. Considering this fact they may indeed be said to lie very near the point where the solution contains no excess of oxygen or hydrogen.

The potential shown by an indifferent electrode in a given solution may be ascribed, then, to two factors, one of them a certain concentration of oxygen or hydrogen, the other a certain concentration of acid or alkali. A potential may be the resultant of many properties in a solution, such as acidity, oxidizing power, degree of ionization or hydrolysis, and the nature of the cations and anions present, but the potential can be interpreted only through the two factors just men- 
tioned. The line of demarcation drawn above, 0.676 volt, applies only to neutral solutions, but every other solution would have a similarly characteristic potential which could easily be calculated and which would determine its oxidizing or reducing power. It is interesting to observe in this connection that, according to Bancroft's original measurements, neutral ferrous sulphate has a single potential of 0.63 - that is, it is feebly reducing according to the above criterion of potential-whereas an acidified solution shows a potential of about $0.79, \mathrm{NaHSO}_{3}$ is given the value 0.66 , and the next neutral oxidizing agent has a considerably higher value. In other words the potential 0.676 fits in very well as a dividing line between "oxidizing" and "reducing" solutions in Bancroft's data although the point of division can not be located exactly, as his measurements included acid and alkaline as well as neutral reagents. ${ }^{1}$

It is a general rule of wide application that if two reactions crn occur simultaneously at the same electrode one will proceed until the potential of the other has been reached. A solution that tends to make an indifferent electrode a cathode combined with a solid that tends to function as anode in water will produce spontaneously a chemical reaction.

By keeping this rule in mind and considering the several possibilities in any given combination we may gain some idea of the nature of the reaction that will occur when a given mineral and solution "are brought together. Consider, for example, a piece of iron and a solution of gold. The table on page 56 shows that a gold solution is an oxidizing solution $(+1.8$ volts) and tends to make any conductor a cathode. Iron $(-0.32$ volt $)$, on the other hand, tends to function as anode. On bringing the two together the iron acts a moment as cathode until some gold is deposited, then as anode, gold being precipitated upon itself and iron going into solution. Since neither action alone is polarizable the combined action is not polarizable and practically all the gold will be precipitated at the expense of the iron.

Now take the combination of pyrite and an acidified ferric sulphate solution. Ferric sulphate solution tends to make any conductor a cathode with very little polarization. On the other hand, if pyrite is made anode in water it is easily polarized and its constituents are partly oxidized. The combined result of pyrite acting simultaneously as cathode and anode in ferric sulphate is that ferric sulphate is reduced to the extent required to polarize the pyrite anodically, a little of the pyrite thereby being oxidized. That this occurs is shown electrically by the electromotive force of the cell:

\section{Platinum / acid ferric sulphate / water / pyrite}

1 Single potentials compiled from Bancroft's data by Ncumann, Ueber das Potential des Wasserstoff und einiger Metalle: Zeitschr. physikal. Chemie, vol. 14, p. 228, 1894. 
that is, by separating the reacting substances, for otherwise no current would be evident. Or it may be shown chemically as follows: If pyrite is placed in a very dilute solution of potassium ferricyanide at the right concentration a precipitate of Turnbull's blue will be formed slowly from ferrous salt dissolved from the pyrite and the ferricyanide. If, however, some acidified ferric sulphate solution is added the precipitate forms rapidly a thin adhering blue film on the pyrite. The explanation of this action is that the ferric sulphate is slightly reduced and the pyrite is oxidized, so that a reaction occurs in the boundary layer. It is possible to obtain such coatings quickly on many minerals by using solutions well separated from them in the potential series.

A combination of any pair of the solutions or conductors whose single potentials are given in the table on page 56 will constitute a cell that will yield an electric current on completing the circuit. Some of these cells will be very easily polarizable and others less so, as was shown in the earlier pages. An extended study of polarization would undoubtedly disclose interesting relations between rates of oxidation, diffusion, porosity, and other factors, but this study must be reserved for another time. The table plainly indicates, however, in general, the degree of compatibility of various solutions and minerals with each other; the nearer equal their potentials the greater will be the chance of compatibility.

\section{APPLICATION TO ORE DEPOSITION.}

GENERAL CONDITIONS.

It is evident from the preceding discussion that ore deposits are likely to be the seat of countless differences in electric potential between both ores and solutions, the whole system being instable and subject to continuous change. Geologic changes expose large areas to chemical attack. Chemical differences thus produced will generate electromotive forces, which, if opportunity is afforded, will produce currents operating to equalize the differences in potential. Diffusion in and through the solutions will also generate feeble electric currents and, conversely, electric currents may influence the diffusion and transference of matter. The greater electric conductivity of solutions as compared with conducting minerals will probably restrict the currents to solutions wherever two courses may be possible.

If a particle of ore without electric potential could be transferred in that condition to a solution it would at once assume an electric charge. Without attempting to explain this phenomenon, one may say that the particle of ore has become slightly polarized and will remain polarized until the system is reduced to electric uni- 
formity by chemical action or until there is an addition or subtraction of electricity. While it is in the solution the ore will be protected somewhat from chemical attack or, on the other hand, it may be made more liable to attack, according as the polarization is positive or negative. If a current is generated a chemical change will occur either in the ore or in the solutions bathing the ore. It has been shown that when the current is in the direction "solution to ore" the chemical change is a "reduction." Conversely, a current from ore to solution must be accompanied by oxidation. Whatever may be the course of the current, secondary reactions may cause the precipitation of insoluble films on the minerals that form the electrodes.

It is conceivable that differences in degree of polarization might affect the growth or solution of minerals and thus lead to variation in crystal form, distortion, unequal development of the different faces, and like effects. The polarization need not be caused wholly by the solution immediately in contact with an ore; it might be the result of electric activity at another point, the current being transmitted through the conducting ore. Though crystallization and solution are affected by foreign salts in solution no attempt has been made, so far as I am aware, to correlate these effects with electric conditions, partly, no doubt, for the reason that the crystallization of electrically conducting minerals can not be studied under conditions as favorable as those available for the study of the crystallization of more soluble substances. If it is granted that different crystal faces have different solubilities this fact would demand as a corollary that there should be different degrees of electric polarization on the different faces.

Electric activity is most likely to come into play in ore deposits, however, when a single mineral or body of ore is bathed by different solutions at different places. The electric circuit afforded by such conditions would be like the following cell:

+ Pyrite / acid ferric sulphate / potassium chloride / sodium sulphide / pyrite-

If, on the other hand, two different minerals are involved, the cell may be of a simpler type, like the following:

$$
\text { + Marcasite / potassium chloride / galena- }
$$

or

+ Marcasite / potassium chloride / sodium sulphide / pyrite -

At each of the above electrodes some local action, either chemical or electric, would doubtless occur immediately; there would remain a residual potential, howerer, which would be available for producing further effects, possibly at more or less remote points. 
If a considerable mass of ore is in contact near the surface with an oxidizing solution-for example, acidified ferric sulphate-and at depth with a less oxidized solution-as ferrous sulphate (there being also any circuitous liquid connection) - electric action should result in the oxidation of the lower solution and reduction of the upper solution until equilibrium is attained. The current would pass downward in the solid conductor and upward in the electrolytic conductor-a vein solution, for example-in which the current would consist in the migration of cations upward and of anions downward. Practically every kind of solution could function to some extent at either one end or the other of the cell suggested. Cathodic effects, such as those described on page 21, would occur chiefly at the upper levels; anodic effects would predominate at the lower levels.

By such "chemical action at a distance" ${ }_{1}$ it would seem that the oxidizing and reducing zones would be extended either in one direction or the other somewhat faster and possibly further than by diffusion alone. ${ }^{2}$ As a matter of fact the process should probably be conceived not as extending from a given point to a remote point but as creeping along veins by local action, producing an extended zone at an intermediate stage of oxidation or reduction.

In the action suggested above the prime mover, of course, is the ferric sulphate produced by the oxidizing power of the atmosphere, and this oxidizing power of the surface solution is available through electric action at points in front of or below the oxidizing solution. In the same way a reducing solution at depth could exert an influence above it through electric action. As coming events cast their shadows before, a solution of sodium sulphide rising through a metalliferous vein system would by electric action tend to precipitate gold, silver, and copper on the minerals above. Of course, there would be a limit to the extent of either action, a limit set by a lack of proper electric circuits and by polarization, but the essential point is that electric action may cause "chemical action at a distance."

\section{DEPOSITION OF ORES.}

Ores are doubtless formed in a great many ways. Some sulphides appear to have been segregated during periods of igneous activity; others occur where obviously there was no igneous activity. In all the varied changes to which the compounds of the valuable metals are subjected fractional solution and precipitation seem to predominate.

1 Ostwald, Wilhelm, Das Chemometer: Zeitschr. physikal. Chemie, vol. 15, p. 399, 1894.

2 Percolation is entirely another matter and may be fast or slow according to the geologic structure. The electric effects must be of approximately the same order as those of diffusion, yet they may be superposed on diffusion effects and also may set up a selective diffusion of certain ions. 
According to Lindgren ${ }^{1}$ the chief causes that produce ore precipitation from aqueous solutions are (1) mingling with other waters and (2) reducing agents. It is in the course of these changes that electric activity becomes a factor demanding consideration. One way in which electric action may effect at least ore solutions, and presumably the deposition of ores, by equalizing chemical differences along veins has been mentioned. Another effect of electric activity would be to keep the ores in a polarized state. The citation of known facts to explain the deposition of sulphides must necessarily be conjoined with qualifications due to uncertainty about the solutions. In general, however, the phenomena of deposition would probably be the reverse of those of solution. Other things being equal, an electric potential at which one mineral would be stable might differ from that at which another mineral would be stable. The several sulphides are by no means equally precipitable from solutions containing two or more metallic salts, and though that fact has heretofore been ascribed wholly to specific differences in solubility, there may be reciprocal relations between the electro-affinities of the metals and their precipitation by a sulphide which should be elucidated.

In considering the protection from chemical action afforded by electric polarization, it may be recalled that some metals are rendered "passive" by making them anodes for a short time. Similarly, the polarization of sulphides by positive electrification would undoubtedly preserve them by maintaining around them a film of hydrogen sulphide. Some years ago A. N. Winchell ${ }^{2}$ studied the rate of solution of pyrite under certain conditions. His results are almost valueless for our present purposes because, unfortunately, he placed the pyrite upon a screen of metallic aluminum, which must have formed an electrolytic couple with the pyrite and to some extent protected it. Winchell noted the presence of aluminum salt in the solution. Recently Graton and Murdoch ${ }^{3}$ have called attention to the fact that pyrite is one of the last of the sulphides to succumb to alteration but note that in decomposing it maintains a bright, clean appearance. The measurements of its potential are consistent with these facts and the brightening effect of a very feeble cathodic polarization of pyrite was noted in the electrolytic experiments.

With a large current almost any metal may be plated out on sulphides; with a smaller current and potential, however, a sulphide may be formed instead of the free metal, just as a forced electrolysis of an acid or of an alkali salt with a mineral sulphide electrode

1 Lindgren, Waldemar, Jcon. Geology, vol. 1, p. 40, 1905.

2 Winchell, $\Lambda$. N., The oxidation of pyrite: Econ. Gcology, vol. 2, p. $291,1907$.

Graton, L. C., and Murdoch, J., The sulphide ores of copper, some results of microscopic study: Am. Inst. Min. Eng. Trans., Feb., 1913.

$33477^{\circ}-$ Bull. $548-14-5$ 
evolves hydrogen, whereas a feeble current generates a soluble sulphide. Even feeble currents ordinarily precipitate only free gold or silver, but the slow precipitation of copper on even pyrite might produce some cuprous sulphide. So far, however, cuprous sulphide has not been produced electrolytically under conditions that would afford unquestionable results. In the electrodeposition of copper for analytical purposes, in the presence of sulphates, the copper is sometimes tarnished by sulphide, but it is doubtful whether this observation is applicable in a theory of ore deposition. If, however, electric currents might direct metallic ions toward the conducting sulphides, the metathetical reactions which would then occur are clearly indicated by Schürmann's series. ${ }^{1}$ The suspicion that electric factors are not wholly negligible, even in metathetical reactions involving metallic ions, is greatly strengthened by the fact that there is a rough parallelism between Schürmann's series and the "electrolytic potential" series of the metals to be considered below. At present, however, there are absolutely no data on the subject.

More definite statements can be made about the metals than about the sulphides, as their behavior has been shown by many experiments in electroanalysis and related chemical processes. From a mixture of metallic salts in solution the metal of lowest solution tension will tend to deposit first in electrolysis, in accordance with the well-known "deposition potentials." The following table of electrolytic potentials gives the value assumed by the metal in a solution normal with respect to the metallic ion: ${ }^{2}$

\section{Electrolytic potentials.}

\begin{tabular}{l|l|l|l}
$\mathrm{Au}+1.356$ & $\mathrm{Sb}+0.743$ & $\mathrm{H}+0.277$ & $\mathrm{Tl}-0.045$ \\
$\mathrm{Pt}+1.140$ & $\mathrm{Bi}+.688$ & $\mathrm{~Pb}+.129$ & $\mathrm{Fe}-.063$ \\
$\mathrm{Pd}+1.066$ & $\mathrm{As}+.570$ & $\mathrm{Sn}+.085$ & $\mathrm{Cd}-.143$ \\
$\mathrm{Ag}+1.048$ & $\mathrm{Cu}+.608$ & $\mathrm{Ni}+.049$ & $\mathrm{Zn}-.493$ \\
$\mathrm{Hg}+1.027$ & & $\mathrm{Co}+.045$ & $\mathrm{Mn}-.798$
\end{tabular}

Some of the above values have been changed from time to time as better determinations of the ionic concentrations have been made, the latest value for silver being 1.06 volts, and for gold, about $1.8 .^{3}$

It will be noticed that gold, platinum, palladium, silver, and mercury show higher potentials in normal solutions of their respective ions than most of the minerals that have been studied show in salt solutions. Therefore, in cells constructed as follows:

+ Metal / metal solution / potassium chloride / conducting mineralthese metals deposit spontaneously until polarization puts a stop to the action. In such a cell the mineral is oxidized simultaneously

\footnotetext{
1 For the latest discussion of the application of this series see Emmons, W. H., The enrichment of sulphide ores: U. S. Geol. Survey Bull. 529, 1913.

2 Wilsmore, N. T., Ueber Elektroden-Potentiale: Zeitschr. physikal. Chemie, vol. 35, p. 318, 1900.

$3 \mathrm{~A} \mathrm{begg,} \mathrm{Handbuch} \mathrm{der} \mathrm{anorganischen} \mathrm{Chemie,} \mathrm{vol.} \mathrm{2,} \mathrm{pt.} \mathrm{1,} \mathrm{pp.} \mathrm{674,} \mathrm{788,} 1908$.
} 
with the deposition of the gold, silver, or other metal. In speculating on the starting of such action in nature it may be noted that most specimens not only have "points of weakness" but that in nature several sulphides are likely to be in association so that deposition seems likely to start unequally. No specimens of commercial iron and steel are so uniform throughout in composition or texture that some local electric action does not occur when they are immersed in solution. ${ }^{1}$ In such specimens there are always some points of greater "solution tension" than others. We may perhaps assume that ores will also vary somewhat in structure or composition. When deposition has started, the metal deposited is very likely to serve as cathode for the deposition of more, and the principal factor limiting electric action is then the polarizability of the oxidizing sulphide. (See p. 18.) In this way the natural occurrence of filaments and nuggets may be very readily explained as due to electrodeposition in which the oxidation of a mineral more or less removed from the metal, if only still connected by the thinnest metallic thread, is an essential part of the process. That silver deposited by electrolysis is prone to form beautiful crystals is well known, although I am not aware that gold crystals have been so produced in the laboratory. I have observed nuggets of gold, however, which possessed a crystalline "treelike" structure exactly like that so well manifested by silver.

In order to see how solutions of the above-mentioned metals would affect pyrite, the following experiments were performed: Small weighed pieces of pyrite were placed in solutions of gold, platinum, and silver. It was found that 5.2 milligrams of gold were precipitated on a gram of pyrite in two days from a chlorauric acid solution. Platinum was not visibly deposited in the same time from a chlorplatinic acid solution, but after several days 0.4 milligram was deposited. A piece of pyrite gained 0.3 milligram after standing in a silver nitrate solution for 10 days. ${ }^{2}$

A number of qualitative experiments of a similar character are described by Skey. ${ }^{3}$ One or two quotations will show the nature of his experiments:

I therefore agitated a little finely powdered galena with a weak solution of terchloride of gold, omitting the addition of organic matter and taking every precaution against its presence accidentally, when I found, after a little while, the gold solution had become quite colorless, and on testing it not a trace of this metal could be found;

1 Cushman and Gardner, Corrosion and preservation of iron and steel, p. 51, 1910.

${ }^{2}$ Very interesting and much more extended experiments of a like nature have since been made by Chase Palmer and E. S. Bastin, who investigated the behavior of a large number of metallic minerals as precipitants of silver and gold and classified them with regard to their activities. See Econ. Geology, vol. 8, pp. 190-170, 1913. Sce also the results of the work of $\Lambda$. C. Spencer, in Econ. Geology, vol. 8, p. $629,1913$.

${ }^{3}$ Skej, W., On the reduction of certain metals from their solution by metallic sulphides, and the relation of this to the occurrence of such motals in the native state: Now Zealand Inst. T'rans. and P'roc., vol. 3, p. 225,1570 . 
it had evidently been absorbed, as it were, by the galena, and, in fact, a careful inspection of the mineral showed it to be feebly gilded.

Chloride of gold was also found to be reduced by contact with the following sulphides-sulphides of iron, copper, zinc, tin, molybdenum, lead, mercury, silver, antimony, bismuth, arsenic, platinum, and gold; and among the arsenides, mispickel and arsenide of silver; cubical iron pyrites is rather slow in its action upon this solution of gold, while sulphide of antimony scarcely affects it at all at first, but after some hours contact with it reduction goes on rapidly, perhaps by aid of some voltaic action. All these effects were produced at common temperatures (with the exception of that with sulphide of bismuth), while other experiments with iron and copper pyrites prove that similar effects are produced when all kind of light is excluded, so there is no reason to suppose that light has been concerned in any of these reactions. ***

A portion of the metal of the sulphide operated upon was uniformly found in the solution afterward, and also sulphuric acid; the mode, therefore, in which these effects were produced was evidently by the oxidation of both the constituents of the nucleus employed at the expense of the chloride of gold. *** Enough has been discovered to show that silver and one or more of the metals of the platinum series are reduced from their soluble salts by these substances generally. * * *

When common iron pyrites and galena are placed in dilute acids or saline solutions within a short distance of each other and connected by platinum wires with a solution of gold chloride contained in a separate vessel, it will be found, after the expiration of a few hours, that the wire connected with the galena has been well gilded over that end of it submerged in the gold solution * * *.

These results, taken in connection with the abundance of metallic sulphides in many of our mineral veins and rocks, make it appear very probable that much of our native gold, silver, and platinum have been electrodeposited from saline solutions by voltaic action set up by the contact of dissimilar sulphides, or sulphides with more negative substances, such as hematite, magnetite, or ferruginous rocks.

The tendency of metals to precipitate by electrodeposition may be expressed quantitatively by the well-known formulas for the potentials of concentration cells. Since this tendency decreases with diminishing concentration, it should be possible to calculate the degree of dilution at which solutions of gold, copper, or silver would cease to deposit the metals at a given potential. The calculation is as follows: Let the given potential be +0.50 volt, a value about equal to that found for galena in dilute salt solutions: How dilute must a solution of a metal be to give this potential against the metal ?

The following equations express the relation between the potentials of gold, silver, and copper in solutions of their salts and the concentrations of the salts:

$$
\begin{aligned}
& \mathrm{E}_{\mathrm{Cu}^{+}}{ }^{+}=0.61+0.029 \log \mathrm{C}_{\mathrm{Cu}^{++}}{ }^{++} \\
& \mathrm{E}_{\mathrm{Ag}}{ }^{+}=1.06+0.059 \log \mathrm{C}_{\mathrm{Ag}^{+}}{ }^{+} \\
& \mathrm{E}_{\mathrm{Au}}{ }^{+}=1.8+0.059 \log \mathrm{C}_{\mathrm{Au}}{ }^{+}
\end{aligned}
$$

in which $\mathrm{C}$, the concentration of the respective ions $\mathrm{Cu}^{++}, \mathrm{Ag}^{+}$, and $\mathrm{Au}^{+}$, is expressed in gram equivalents per liter. Substituting 0.50 for $\mathrm{E}$ in each equation and solving for $\mathrm{C}$ we have:

$$
\begin{aligned}
& \mathrm{C}_{\mathrm{Cu}^{++}}=4.2 \times 10^{-4} \\
& \mathrm{C}_{\mathrm{Ag}^{+}}=1.1 \times 10^{-10} \\
& \mathrm{C}_{\mathrm{Au}}{ }^{+}=0.9 \times 10^{-22}
\end{aligned}
$$


Solutions whose normality is lower than the numbers just given would have no tendency to overcome a voltage of +0.50 . It is seen that such a solution would be exceedingly dilute for gold (not quite so dilute for the metal as the number given for the aurous ion because gold solutions are not completely ionized into aurous ion, but still very dilute), very dilute for silver, and rather dilute for copper. Similar calculation could be made for other potentials than 0.50 volt.

Deposition of the valuable metals could be brought about not only at the expense of an oxidizable mineral in the manner just considered but also by a combination of a rather inert minera! like pyrite with any reducing solution. The cell would be of this form:

\section{+ Pyrite / metal solution / reducing solution / pyrite-}

As a very simple demonstration of this mode of action in the deposition of silver from silver sulphate by sodium sulphide the following experiment was performed: $A$ few drops of silver sulphate solution were placed on the smooth face of a large crystal of pyrite. Some distance away, on the same crystal, a few drops of sodium sulphide were placed. The two solutions were then connected by a small $\mathrm{U}$-shaped capillary tube filled with water. In the course of an hour erystals of silver could be distinguished on the pyrite in the silver sulphate solution. This experiment shows how associations of the valuable metals with conducting minerals may be produced in nature by the electromotive power of reducing solutions at another point. This mode of action was mentioned on page 64 under the heading "General conditions."

The present study is not to emphasize the fact that sulphides, either soluble or insoluble, are capable of reducing solutions of gold, silver, and certain other metals, for that has long been known, but to show that electric action may produce forms and associations of those metals which can not be explained otherwise.

\section{SOLUTION OF ORES.}

The solution of ores may be the result of many different chemical agencies, but the facts presented in the preceding pages indicate that electric action may be one of the factors where conducting minerals are present. The evidence afforded by experiment shows that a current passing from mineral to solution will produce oxidation - of the solution first if it is oxidizable, otherwise of the mineral. The order in which the various solutions would be oxidized is shown by the table on page 56. Alkali sulphides would go first, then alkali hydrosulphides, if present, and finally the ores, if no further redueing agents were present in the solution. Of several ores, the one of lowest potential would tend to be oxidized first. 
Although the order in which the substances other than ores would be oxidized in ore deposits is here stated, it is believed, for the first time, the fact that this principle was applied to ores long ago by Skey seems to have been generally overlooked. Skey says: ${ }^{1}$

In a natural way, therefore, the contact of dissimilar sulphides generally should set up galvanic action and chemical decomposition, and by setting up this action we might have an easily decomposable sulphide preserved by the association with it of one still more ready to decompose.

The increased oxidation of one sulphide in contact with another was noter in chemical studies by Gottschalk and Buehler before they developed an explanation in terms of electric action.

The results of experiments suggest that magnetite, marcasite, pyrite, and chalcopyrite should be more resistant to oxidation, and that chalcocite, pyrrhotite, and galena should be oxidized more rapidly than the former when in contact with them. A very important factor in any electric action, however, is the polarizability of the electrodes. The study of their polarizability showed that certain minerals were oxidized in the following order, the series beginning with the one which would be oxidized most rapidly: Iron, copper, silver, chalcocite, galena, pyrrhotite, covellite, marcasite, chalcopyrite, pyrite, and magnetite. It should be emphasized that this series shows speed effects, which may constitute an important factor in the alteration of the ores. The series by itself is probably not sufficient to indicate an order of occurrence in nature, nor does the order correspond exactly with the electromotive series; both series are significant, but their application must depend on the nature of the conception of the phenomena taking place in ore deposits-that is, whether they are viewed as equilibria or as effects of varying rates of oxidation. With the principle that the mineral of lowest potential will tend to be oxidized first must therefore be linked a second principlethat every electrolytic process is accompanied by corresponding polarization. For example, pyrrhotite shows a lower potential than pyrite in a salt solution, but if a current passes from the pyrrhotite to the pyrite through the solution it forms alkali sulphide around the pyrite and the effective electromotive force falls to millivolts or less. There are countereffects in electrolytic action at every stage, and the speed of such action would under many conditions be limited by processes of diffusion.

Electrochemists are familiar with a class of feeble currents known as "residual currents." For example, the application of a low electromotive force to the electrolysis of water with platinum electrodes soon "polarizes" the electrodes with hydrogen and oxygen; further current flows only as fast as the gases dissolve in the solution and dif-

1 Op. cit., p. 224. See Hunt, Geol. Survey Great Britain, Mem. vol. 1. 
fuse out of it into the air. The disappearance of an unstable mineral might be the supposed ultimate result of electric action between two or more ores, but practically this would occur very slowly on account of the accumulation of certain products of the reaction; in short, an equilibrium would be attained which would by no means be incompatible with the existence of two or more minerals. The disappearance of one would require a very long continued supply of fresh solution and the removal of the solution products. Specially rapid action, however, would be developed by the alternate drying and wetting of particles of different ores in contact. Traces of ferric salts that would form on iron minerals when dry would exert high potentials when moistened. This seems to be the condition under which Gottschalk and Buehler obtained the most notable effect of acceleration in the oxidation of one sulphide by another in the laboratory.

It is hardly necessary to point out that the order of solution of metals under electric action would be the opposite of the order of their precipitation-that is, when in contact the base metals would oxidize and dissolve first, then copper before silver, and finally silver before gold. Speaking broadly, the base metals would also protect most sulphides from oxidation if in contact with them in the presence of water, and the sulphides would protect silver and gold. Native silver and gold, as we now find them, may therefore have been held in their present position for a long time partly by the presence of sulphides which have now just about disappeared.

To summarize the electric activity of ores very briefly: Contact with solutions as well as certain other conditions impart electric potentials to conducting minerals. When local or electrolytic action is possible the chemical and electric differences will proceed toward equalization by processes of diffusion, decomposition, solution, oxidation, and reduction until the system reaches electrochemical equilibrium. Measurements of potentials are helpful in indicating the direction of possible changes and in giving a quantitative statement of the intensity by which the differences tend to become equalized.

All the experimental results on electric potentials that are here reported or that may hereafter be presented must necessarily be in harmony with natural occurrences, for electric potentials are a quantitative expression of the intensity factor of the "available" energy in chemical systems, and every change that takes place spontaneously in a system in nature can do so only with a diminution of the "available" energy. Where electric conductors are present, electric activity therefore goes on simultaneously with chemical activity and is a means by which chemical differences can frequently be adjusted more rapidly than otherwise. 


\section{SUMMARY.}

A large number of metalliferous minerals are capable of conducting electricity and could therefore function as electrodes and as conductors for electric currents in ore deposits. In this paper only bare mention has been made of the possible existence of induced earth currents and thermoelectric currents, inasmuch as the field results of Barus on this point were almost wholly negative. It has been shown, however, that the energy which ordinarily manifests itself in chemical reactions may be, and in fact will be, manifested to some extent in electric action whenever the proper circuits are present. Conditions for electric action in ore deposits are by no means unusual. One of the simplest possible combinations by which electric action could occur would consist in the presence of two different active solutions in contact with a single body of ore, the two active solutions being united by any "indifferent" electrolyte. The combination suggested would have many ramifying variations, depending on the amounts of solution available, the position of the ores, and other like factors. The effects of electric action are naturally somewhat different from those which would result from direct admixture of solutions and entirely different mineral associations might be produced through such action.

The chemical difference producing the largest electric effects appears to be that existing between oxidizing and reducing solutions. All solutions may be arranged in an electromotive series grading, speaking broadly, from the strongest oxidizing solutions, which will charge an unattackable electrode most positively, to the strongest reducing solutions, which will charge it most negatively. It has been found that pyrite, and, to a less extent, several other minerals, are so inert to many solutions as to function electrically like "unattackable" electrodes for long periods, thus making oxidizing or reducing solutions available for producing electric currents in ore deposits. The solution products of minerals themselves may take part in producing currents in the absence of more active substances; accordingly, different minerals show different electromotive forces in "water."

The currents generated in any of these ways may cause effects at more or less remote points. Electric action on a large scale would tend to maintain a common level of oxidization along veins and large bodies of ore; where it is effective, the zones of oxidation and reduction would depend on the structure of the ore rather than on depth. Electric action on a small scale would polarize ores feebly, favoring the disappearance of unstable ores and protecting stable ores up to the point of equilibrium. The cathodic and anodic phenomena attending the passage of a current from a solution to a mineral, or vice versa, 
have been studied in some detail. It has been found that mineral electrodes possess various degrees of polarizability. The polarization of minerals would doubtless to some extent influence metathetical reactions in ore deposits. Feeble currents might also give a directional trend to metallic ions that would carry them toward the stable minerals. Under many conditions the valuable metals would be deposited from solutions by electrolytic action and they would thereafter be protected from redissolving by contact with any of the more oxidizable ores. 



\section{INDEX.}

A.

Abt, A., thermoelectric series of. Air, apparatus for boiling out, figure showing. $\quad 35$ exclusion of, effect on potential........36,39, 42

Alkalinity, development of, by electric action. 22 effect of, on oxidizing power.............. 60

Allen, E. T., cited ........................ 9

Antimony, potential of .................... 56

B.

Bancroft, W. D., experiments of........... 11,47,61

Barus, Carl, work of.................... 5,6,8,72

Bastin, E. S., work of...................... 6

Batteries, natural, occurrence of.............. 20

Becker, G. F., cited.......................... 20

work of................................ 5

Becquerel, ..C., cited...................... 8

Behrend, R., cited.......................... 45

Bernfeld, I., cited................ 9, 22, 25, 43, 44

Bismuth, sulphide, potential of.............. 44

Braun, F., cited........................ 8, 25

Brokaw, A. D., work of................... 5

Buehler, V. A., and Gottschalk, H. A., work of.................... 5,6,9,70,71

C.

Cadmium, potential of

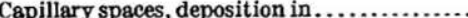

in galens, polarization in................ 22

Cathode combination, definition of.......... 21

Chalcocite, polarization of................. 16,18

Chalcocite, potential of ................... 15,29

Chalcopyrite, polarization of ................ 17,18

potential of.......................... 35

Chemical action, possible range of............ 64

Chemical differences, electromotive force generated by............ 19-20,62,71,72

Chemical reduction, relation of, to electric reduction..................... 19-20

Cobalt, potential of, in a soluble sulphide.... 45

Compatibility of minerals and solutions... 55,61,62

Comstock lode, electric activity in .......... 8

Conductivity of minerals, irregularities in data on........................ 25

scale of ........................... 24-25

Conductivity of solutions .................. 21

Copper, electro deposition of, on pyrite..... 21, 66 polarization of........................ 18 potential of, in a soluble sulphide...... 45 in water....................... 56

in solutions of cupric salts.......... 6s-69

Corrosion by electric action, occurrence of.... 9,21

Covellite, polarization of............... 16,17,18

Crystals, formation of, possible electric influences on .................... 63

Cupric chloride, electric reduction of......... 23

Cuprous chloride, electroly tic production of.. 22 potential of.
Currents, earth, residual, origin of .......... 14-15 production of, by a difference in the electrode...................... 15

by a difference in the solution........ 14

D.

Deposition, electric, conditions of..........65-66

of metals on minerals, occurrence of..... 21

Depth, relation of, to electric potential..... $7,12,64$

Diffusion, electromotive force developed by.. 20,62

Dufet, H., cited.

25

E.

Earth, electric currents in .........: 19-21,26,62-73 electric currents in, intensity of........ 20,72 free oxygen and hydrogen in solutions in. $\quad 60$ See also Ores; Depth.

Electric reduction, relation of, to chemical reduction................. 19-20, 71

Electrodes, polarization of .................. 12-18

Electrodes, mineral and platinum, comparison of ............................ 10

supply of solution to, without air, figure showing........................ 27

Electrolysis, alteration by.....................21-23

of minerals, as anodes.................... 23

as cathodes........................ 21

Electrolyte, variation in, effect of........... 9-11 Sec also Solutions.

Electroly tic potentials, table of............. 66

Electromotive force, direction of, between minerals.

magnitude and continuance of from minerals......................... 12-19

experiments in, figure illustrating... 13

measurement of, method of............. 26

relation of, to chemical differences..... 11,71,72

Electromotive scale of minerals, investigation of ......................... 8,56

Electrostatic separation, theory of ........... 24

Emmons, W. H., work of................... 6

Error, source of, in measurements involving sodium hydrosulphide........... 49

Eureka, Nev., electromotive forces at........ 8 F.

Faraday, M., cited......................... 25

Ferric-ferrous sulphate solution, effect of, on potentials...................... 27

reduction of ....................... 19-20,27

effects of......................... 21-23

Ferric sulphate solution, effect of, on potentials.......... 13,13-14, 17-18, 28, 32,36

effect of, on potentials, apparatus for ascertaining ..................... 28

apparatus for ascertaining, figure showing...................... 27

potential of.

56 
Ferrous sulphate solution, effect of, on potentisl. potential of of.

Fisher, $r$, cited

Fox, R. W., cited.

G.

Galena, behavior of, with acids........... 42 electrodeposition on.................. 68 polarization of ..................... 16, 18 potential of....... 10,14-18, 28, $29,35,42-44,56$ effect of solutions on............... 42

Gold, electrodeposition of. . ........ 21, 22, 66-68 polarization of..................... 17, 18 potential of ...................... 56, 68-69 protection of, by sulphides............ 71

Gottschalk, H. A., and Buehler, V. A., work

$$
\text { of. } \ldots \ldots \ldots \ldots \ldots \ldots \ldots \ldots \ldots \ldots, 6,9,70,71
$$

Graton, L. C., work of ................................

Graton, L. C., and Murdoch, J., cited........ 65

$$
\text { H. }
$$

Heberlein, E., and Küster, F. W., cited..... 48

Henwood, W. J., cited.................... 7

Hittorf, W., cited................... 21,47

Hydrogen, action of, on galena............ 36

evolution of, on a mineral electrode...... 21

potential of. ...................... 56,57-60

chart showing.

Hydrogen sulphide, neutralization of excess, in $\mathrm{NaSH} \ldots \ldots \ldots \ldots \ldots \ldots \ldots . . . \ldots \ldots$ relation of to potential.... $36,40,42,46,47,49$

\section{I.}

Ions, migration of, in electric activity........ Iron, electric deposition of, on pyrite polarization of......................... potential of

\section{K.}

Knox, Joseph, cited. $43-44,47-48$

Küster, F. W., cited. ..... 47,51

Küster, F. W., and Heberlein, E., cited.. L.

Lead, potential of .................. 45,56

Lead dioxide, potential of ................. 56

Lead sulphide, artificial, potential of...... 43 See also Gialena.

Lehner, Victor, work of.....................

Leith, C. K., and Van Hise, C. R., work of..

Lew is, G. N., cited.

Lindgren, $\mathrm{VW}$, cited .

Luther, R., eited...................... 12

M.

Magnetite, polarization of

$17,18,41$ potential of. ................. 10,15,41-42 reduction of

Manganese, potential of.................. $\quad 56$

Manganese dioxide. Sce Pyrolusite.

Manganese nitrate, effect of, on potential of pyrolusite.................. 30-31 sulphate, effect of, on potential of pyrolusite..........................

Manganite, potential of.

Marcasite, influence of, on oxidation and solu-

tion ..........................

polarization of . . . . . . . . . . . . .

potential of. ......... 15, 27, 28, 29, 35, 39-41, 56

reduction of electroly te by ............. 22

Membranes, semipermeability of........... 8

Mercuric sulphide, potential of............. 45

Mercury, electric deposition of ......... 22,66-67

potential of........................ 56

Minerals, combinations of solutions and, effects of............. 12-19,60-62,72

currents flowing from solutions to. See Solutions.

disappearance of, conditions governing .. 70,71 electric action of, in solutions of themselves................ 29-30,38,72

electric and chemical oxidation of, relations of .................... 19-20

electromotive scale of. ............ 24-25,56

investigation of. ................. 8,9

observation of, in solution, cell for, figure showing ................... 29

oxidizing powers of . ............... 16,17

polarization of ...................... 12-18

potentials of ..................... 55-56

effect of earlier solution on.......... 30

effect of different solutions on. . 10-14,19,26 apparatus for testing, figure showing.................... 13

in water........................ 29

thermoelectric scale of ............... $\quad 20$

See also Ores.

Minerals, different, potentials of, in the same solution. .................... 15, 19

Murdoch, J., and Graton, L. C., cited....... 65

\section{N.}

Nickel, potential of .................. 45,56

Nuggets, production of................. 67

O.

Ores, combinations of, resemblance of, to galvanic combinations.......... 7

deposition of........................ 64-69 application of electric activity to..... 62-73 beginning of ................... 67 electric currents in, effect of.. $6,65,71,72-73$ generation of ................... 62-64 electric oxidation of.............. 23,69-70 solution of . . . . . . . . . . order of ............................. 71 See also Minerals.

Ostwald, W., cited ................... 8,64 Oxidation, order of, relation of potentials and. $\quad 69$ Oxygen, potential of ............. 56,57-60 potential of, chart showing............ 58

P.

Palladium, electric deposition of ..........66-67

Palmer, Chase, work of .................... 5

Peters, R., cited............... 11

Platinized electrodes, effect of, in sulphide solutions......................... 46 
Page.

Platinum, electrodeposition of $21,22,66-67$ polarization of. $13-15,16,17$ potential of........ 10,13-14, 16-17,28, 29, 35, 56

Polarization, possible cause of, in ores....... 63 effect of, on ore deposition ...........65, 70 of minerals, as anodes. as cathodes. of pyrite in detail.

Polysulphides, soluble, decomposition of

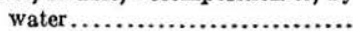

electromotive behavior of. effect of dilution on.

probable complexity of ............... 53-54

Potassium arsenite, potential of

Potassium chlorate solution, effect of, on potential

Potassium chloride solution, effect of, on potential... 10,14-18, 31,34-36, 39, 41, 42, 50

Potential, apparatus for obtaining, of minerals in water................... 38

constancy of.................. 10-11, 26, 29, 34

effect of different solutions on.......... 10,55

oxidation and reduction, variations of... 11

relation of oxidation and................ 69

variation in, relation of, to oxidizing power of solutions............ 11-12

Potential, single, measurement of. ......... 26-45

measurement of, correlation of......... 54-62 errors in, cause of................... 55 See also particular minerals.

Preuner, G., cited...................... 59-60

Prospecting, relation of electric activity to... 6,8

Pyrite, anode and cathode changes in....... 23 electric deposition on ............... 22, 23, 67 influence of, on oxidation and solution.. 9,72 oxidation of.

polarization of.............. 16,17, 18,36-37 chart showing ................... 37 potential of. .... 10, 12-18, 27, 28, 29, 32-39, 54,56 lag in.......................... $37-38$ relation of, to electrolyte.... $32-33,38-39,72$ reduction of ferric sulphate by ....... 19, 21-23 saturated solution of, apparatus for, figure

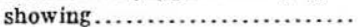
solution of......................... 65

Pyrolusite, polarization of .......... 16, 17, 32 potential of.................... 30-32, 56 reduction of ....................... 22

Pyrrhotite, anode and cathode changes in... 23 polarization of .................. 16,17,18 potential of.............. 10, 15, 27, 29, 41, 56 reduction of electrolyte by ............. 22

\section{R.}

Reductions, effects of electric. $21-23$

Reich, F., cited.

Residual currents, origin of........... 14-15, $70-71$

\section{S.}

Schürmann's series, application of, possible qualification in ................ 66

Silver, electrodeposition of . ...... 21, 22, 66-67, 69 potential of .................. 45, 56, 68-69 protection of, by sulphides........... 71 by copper........................
Silver sulphide, potential of ............ Page.

Skey, W., cited...................... $7-8$ quoted........................6. 67-68,70

Smith, G. O., preface by............... 5-6 Sodium hydrosulphide solution, potential of. $\quad 56$ preparation of..................... $48-49$ source of error in measurements involving ........................... 49

Sodium hydrosulphide, relation of, to potentials............. 28-29, $33,43,44,45$

Sodium hydroxide solution, potential of ..... 56 relation of, to potential ............... 11, $14-15,30-31,32-33,39,41,42,50$

Sodium polysulphide solution, reduction of.. 23 relation of, to potential................. 32 Sodium sulphide solution, dilution of, effect on potential ............... 51-54 potential of ...................... 56 electric formation of, from minerals..... 22.23 relation of, to potential .......... 10,14,33,43 Sodium sulphite, potential of.............. 56 Solutions, character of, importance of, in determining electromotive behav-

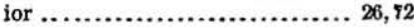
combinations of minerals and, effects of . . . . . . . . .

currents flowing from minerals to....... 23 currents flowing to minerals from, effects of.......................... 21-23 effects of, on mineral potentials........ 6 , $10,12-15,20,26,29-30$

apparatus for testing, figure showing. 13 observation of minerals in, cell for, figure showing.

oxidizing power of, relation of, to potentials..................... 11-12

supply of, to electrodes, without air, figure showing................ 27

variation in, effect of ................ 9-11

Spencer, A. C., work of.................. 67

Stannous ehloride, potential of ........... 56 Stromberg, $\mathbf{A}$. von, cited................ Sulphide electrodes, behavior of . ........49-50 Sulphide potentials, definition of . . . . . . 39,46 Sulphides, iron, potentials of............ 27 Sulphides, solid, thermoelectric action between .................... 20

Sulphides, soluble, bearing of, on behavior shown by minerals............. 54 concentration of, relation of, to potential. . 47-48 electromotive behavior of............ 45-54 potentials of, relation of, to concentration. $47-18$ reducing power of ................. $45-46$

Sulphides as anodes, effect of current on.... 23 Sulphides as eathodes, effect of current on ... 21-23 Sulphur, pcssible ionization of........... 50 potential produced by presence of ...... 49-50 Sulphuric acid, effect of, on potentials. $10,14,30-31,32$ potential of......................... 56

T.

Temperature, effect of, on conductivity..... 25

Thermoelectromotive forces, development of. $\quad 20$ Tower, O. F., on potential of pyrolusite.... 30-31 
v.

Page.

Van Hise, C. R., and Leith, C. K., work of .. W.

Water, potential of minerals in....... 29-30,38, 72 modification of, by dissolved salts....... 56 by metals......................... 57

by minerals.................... 56,60 free oxygen and hydrogen in. \begin{tabular}{r|l}
56,60 & Zengelis, K., cited. \\
59 & Zinc,
\end{tabular}

Wentworth, H. A., on conductivity of min-

erals.

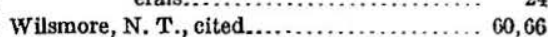

Winchell, $\Lambda . N$., cited.................. 65

$\mathrm{Z}$.

Zinc, potential of .......................... 56 




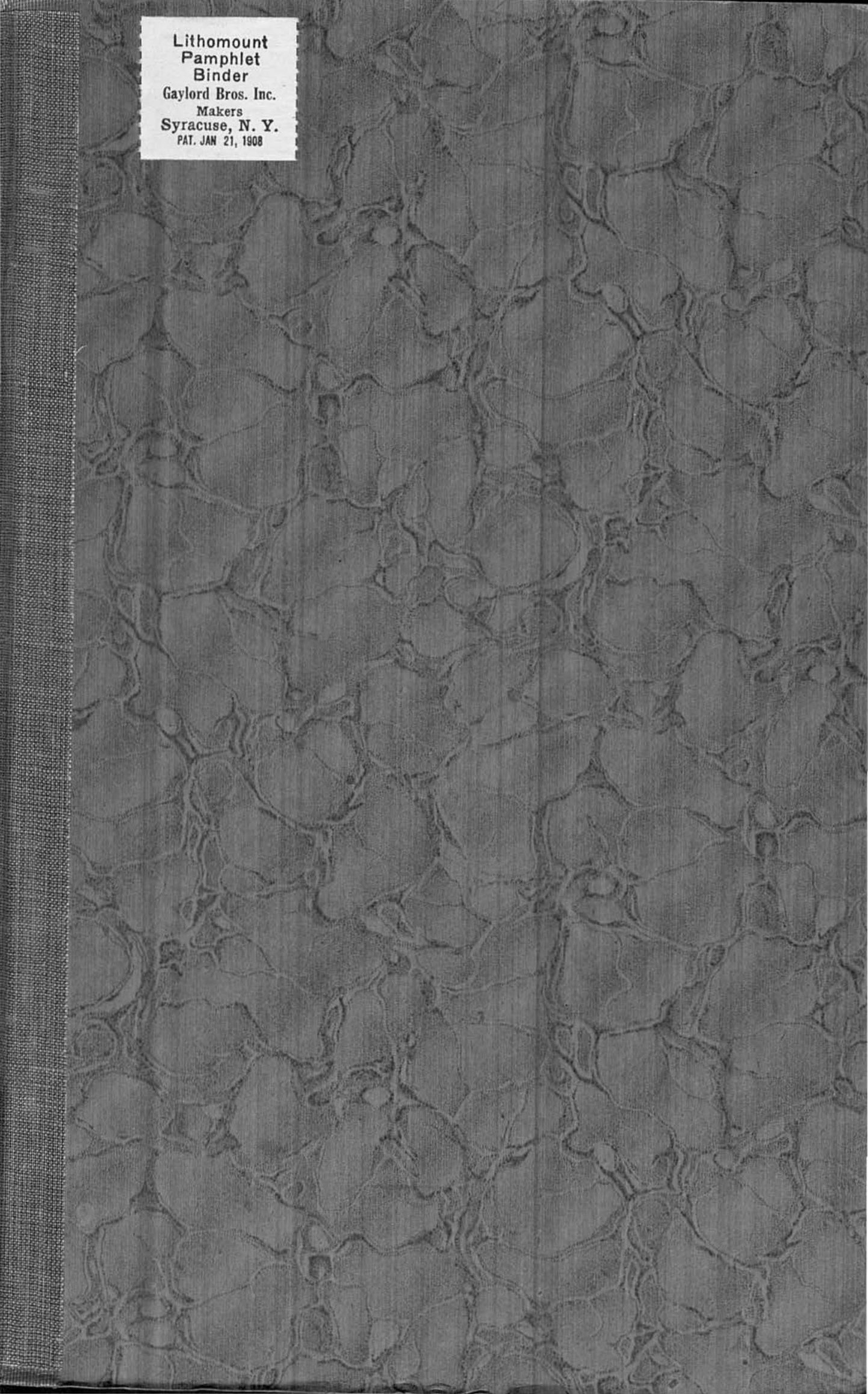




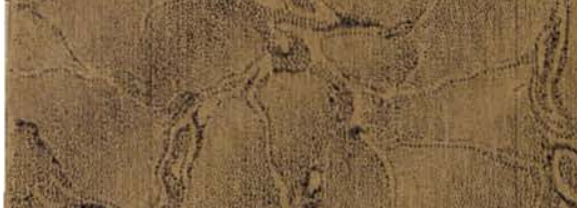

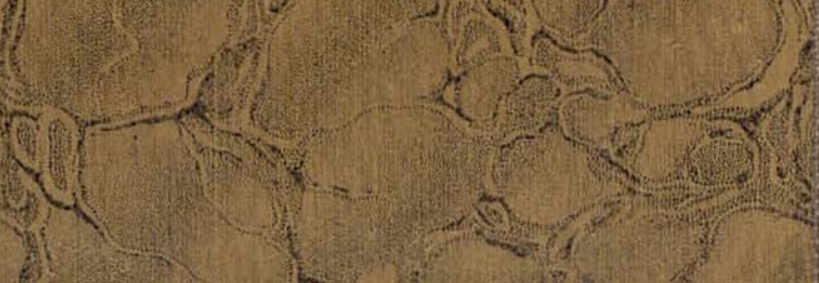

1.5.

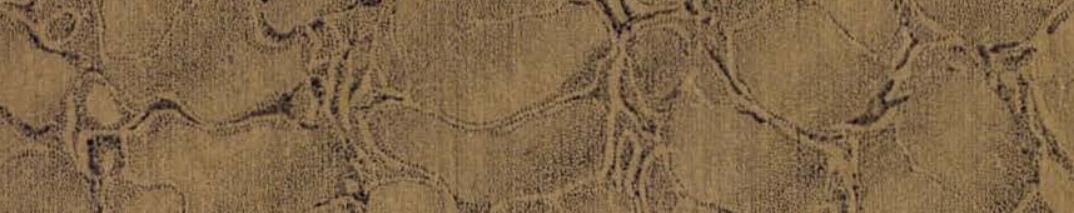

9.

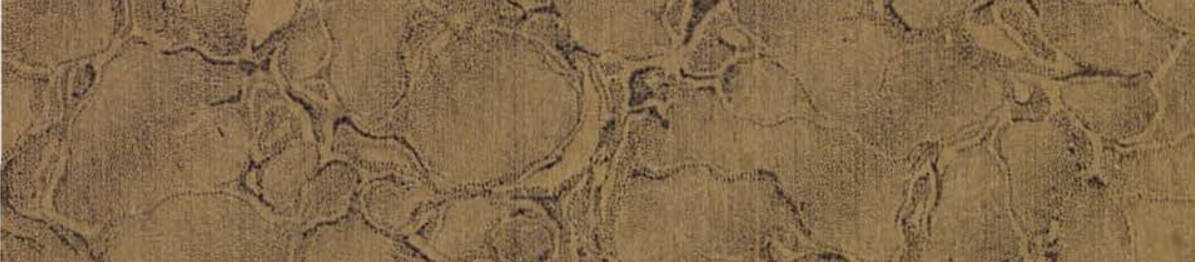

4
4

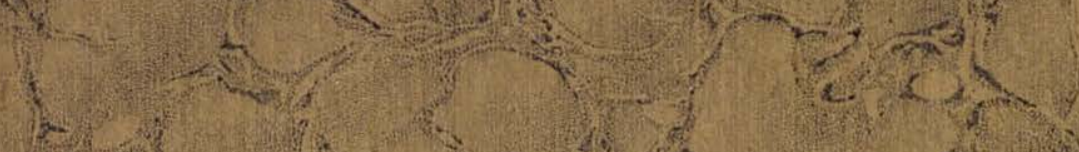

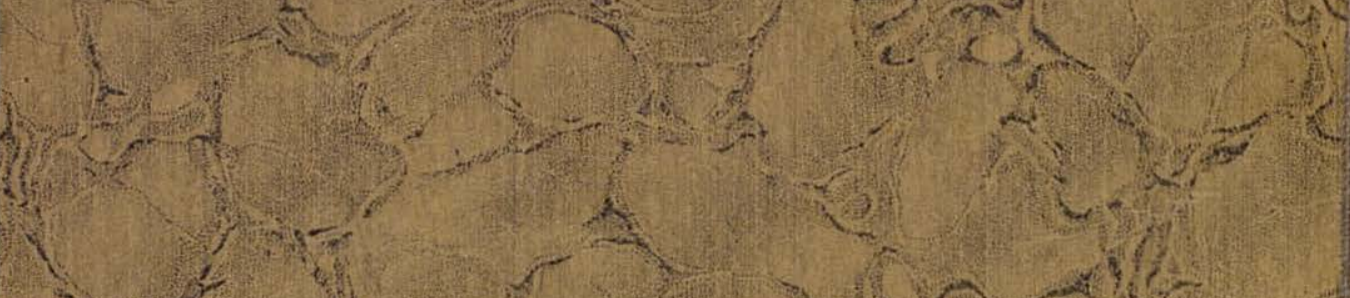

$\frac{1}{2}$

$2=1 t^{2}$

ix

$-c^{2}$

(1).

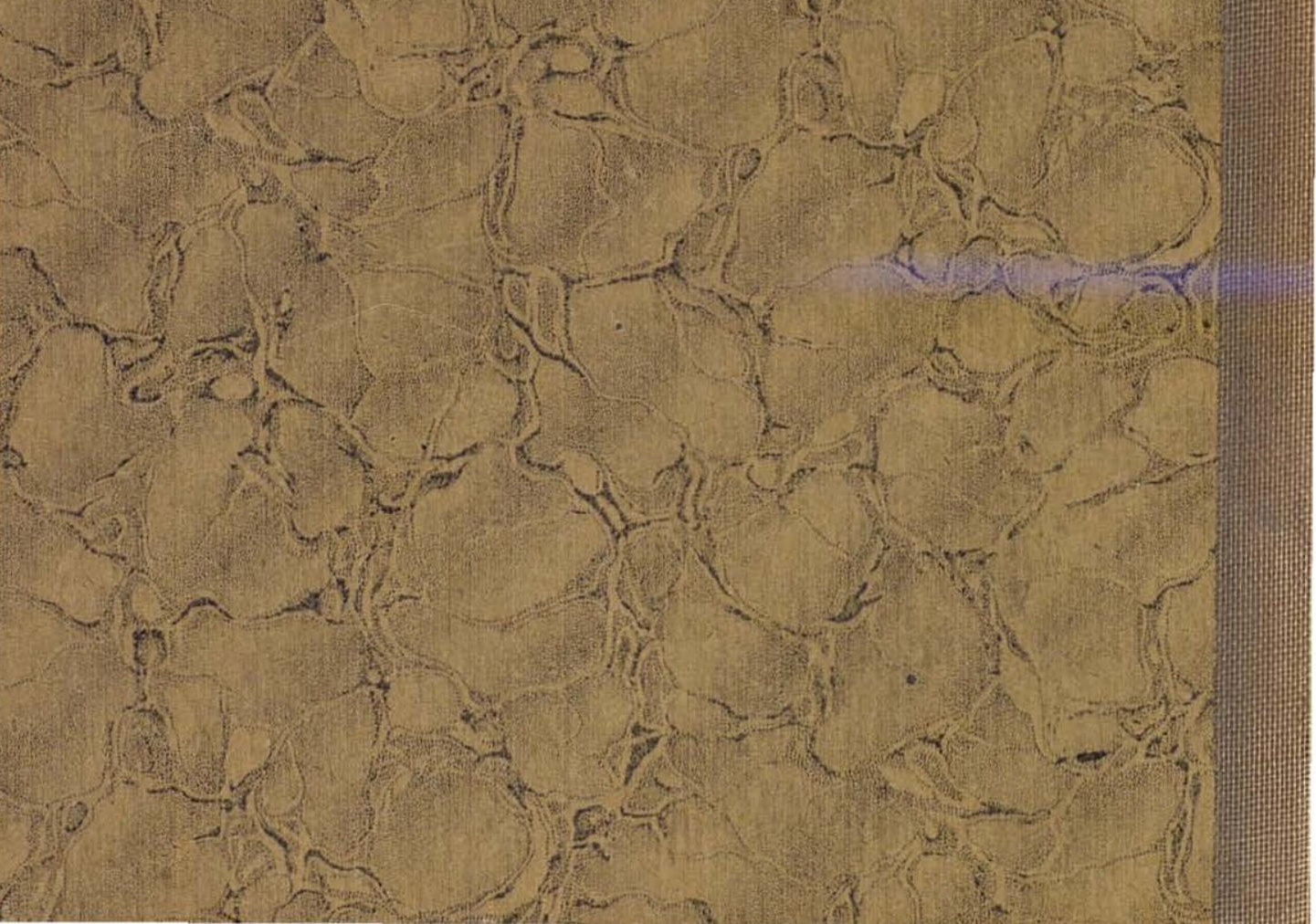

